University of Chicago Law School

Chicago Unbound

Journal Articles

Scholarship

2012

\title{
Historical Gloss and the Separation of Powers
}

Curtis A. Bradley

Trevor W. Morrison

Follow this and additional works at: https://chicagounbound.uchicago.edu/journal_articles

Part of the Law Commons 


\title{
HARVARD LAW REVIEW
}

(C) 2012 by The Harvard Law Review Association

\section{ARTICLES \\ HISTORICAL GLOSS AND THE SEPARATION OF POWERS}

\author{
Curtis A. Bradley and Trevor W. Morrison
}

\section{CONTENTS}

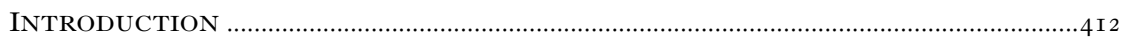

I. Historical PRACtice and Constitutional Interpretation....................... $4 \mathrm{I} 7$

A. Prevalence of the Historical Gloss Argument ………….......................................... 4I 7

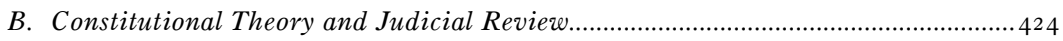

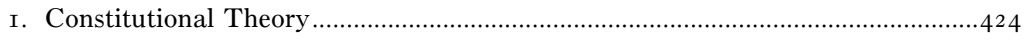

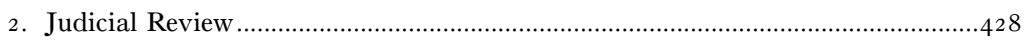

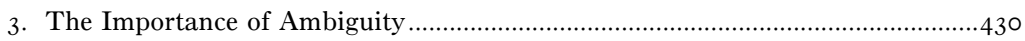

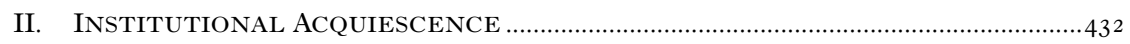

A. The Meaning and Value of Acquiescence …….............................................................

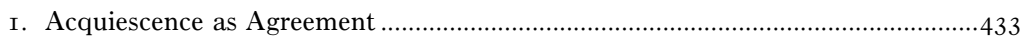

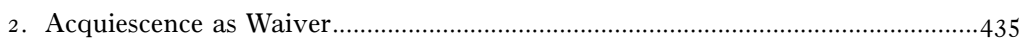

3. Acquiescence and the Limits of Judicial Review ................................................436

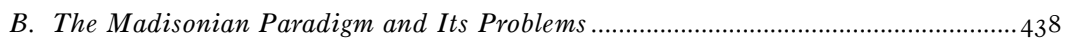

I. Structural Impediments to Congressional Action ..............................................440

2. Political Asymmetries Between Congress and the Presidency ................................44 I

3. Modern Congressional-Executive Relations .............................................................44

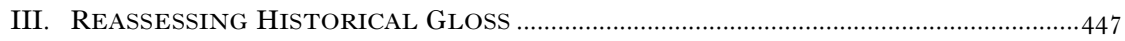

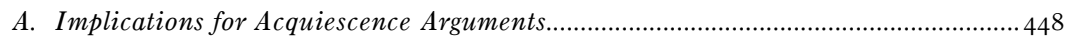

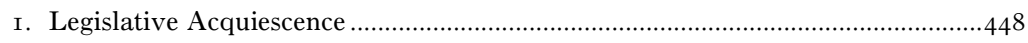

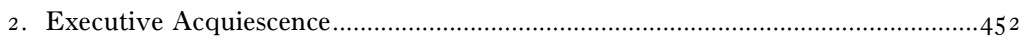

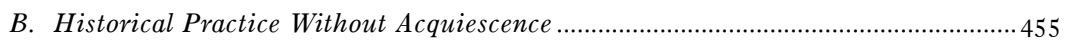

I. Burkean Values and Principled Decisionmaking...................................................45

2. The Legitimacy of Law and the Role of the Courts ...............................................456

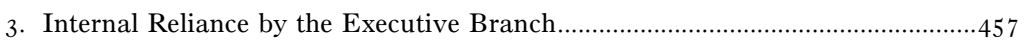

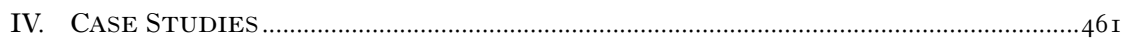

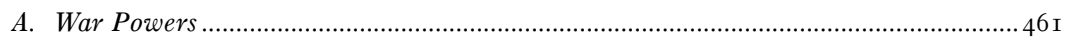

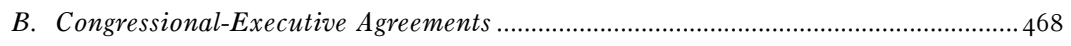

C. Removal of Executive Officers ................................................................................. 476

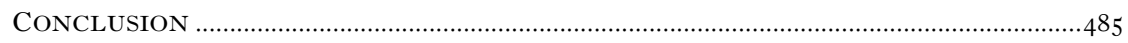




\title{
HISTORICAL GLOSS AND THE SEPARATION OF POWERS
}

\author{
Curtis A. Bradley* and Trevor W. Morrison**
}

\begin{abstract}
Arguments based on historical practice are a mainstay of debates about the constitutional separation of powers. Surprisingly, however, there has been little sustained academic attention to the proper role of historical practice in this context. The scant existing scholarship is either limited to specific subject areas or focused primarily on judicial doctrine without addressing the use of historical practice in broader conceptual or theoretical terms. To the extent that the issue has been discussed, accounts of how historical practice should inform the separation of powers often require "acquiescence" by the branch of government whose prerogatives the practice implicates. Such acquiescence is commonly seen as critical for historical practice to have the force of law. Yet the concept of acquiescence has been treated much too casually in the literature. Claims about acquiescence are typically premised on a Madisonian conception of interbranch competition, pursuant to which Congress and the executive branch are each assumed to have the tools and the motivation to guard against encroachments on their authority. It has become apparent from political science scholarship, however, that the Madisonian model does not accurately reflect the dynamics of modern congressional-executive relations. This fact necessitates a reexamination of the premises and implications of the idea of institutional acquiescence in particular, and of the role of historical practice more generally. Ultimately, we argue, the problems with the Madisonian model are not fatal to crediting historical practice in interpreting the separation of powers. But they do require more attention to the reasons why such practice is invoked, the extent to which these reasons demand institutional acquiescence, and the precise method by which such acquiescence is identified. To illustrate the importance of each of these questions, we present three case studies of constitutional debates concerning the separation of powers in which practice-based arguments are prominent - war powers, congressional-executive agreements, and removal of executive officers.
\end{abstract}

\section{INTRODUCTION}

rguments based on historical practice are a mainstay of debates about the constitutional separation of powers. These arguments

\footnotetext{
* William Van Alstyne Professor of Law, Duke Law School.

** Isidor and Seville Sulzbacher Professor of Law, Columbia Law School.

For helpful comments and suggestions, we thank David Barron, Joseph Blocher, Hal Bruff, Josh Chafetz, Sarah Cleveland, Brannon Denning, Mike Dorf, Ariela Dubler, Dick Fallon, Michael Farbiarz, Martin Flaherty, Michael Gerhardt, Michael Glennon, Jack Goldsmith, Kent Greenawalt, Mitu Gulati, Suzanne Katzenstein, Judge Brett Kavanaugh, Daryl Levinson, John Manning, Peter Margulies, Dan Meltzer, Gillian Metzger, Henry Monaghan, Jide Nzelibe, Rick Pildes, Eric Posner, Jeff Powell, Dan Richman, Chris Schroeder, Neil Siegel, Kevin Stack, Paul Stephan, Peter Strauss, Adrian Vermeule, Matt Waxman, John Witt, Christopher Yoo, Ernie Young, and participants in workshops at Columbia, Duke, Georgetown, the University of Colorado, the University of Pennsylvania, and the University of Texas. For excellent research assistance, we thank Chris Ford, Tati Sainati, and Tom Sprankling.
} 
are especially common in debates over the distribution of authority between Congress and the executive branch. Justice Frankfurter famously emphasized the importance of a practice-based "gloss" on presidential power in his concurrence in the Youngstown steel seizure case, ${ }^{1}$ and the full Supreme Court, executive branch lawyers, and academic commentators frequently invoke historical practice in similar terms. ${ }^{2}$ In 20 I I, for example, the Justice Department's Office of Legal Counsel (OLC) relied heavily on a series of past presidential uses of military force, in which it claimed Congress had acquiesced, to support its conclusion that President Obama had the constitutional authority to conduct military operations in Libya without congressional authorization. ${ }^{3}$ More recently, debates over the scope of the President's power to make "intrasession" recess appointments of federal officials centered heavily on historical practice. ${ }^{4}$

Surprisingly, however, there has been little sustained academic attention to the proper role of historical practice in the context of separation of powers. The scant existing scholarship is either limited to specific subject areas or focused primarily on judicial doctrine, without addressing the use of historical practice in broader conceptual or theoretical terms. ${ }^{5}$ Moreover, the existing literature has not assimilated insights from political science concerning the actual dynamics of

1 See Youngstown Sheet \& Tube Co. v. Sawyer, 343 U.S. 579, 610-I I (I952) (Frankfurter, J., concurring).

2 See infra section I.A, pp. 4I 7-24.

3 See Memorandum Opinion from Caroline D. Krass, Principal Deputy Assistant Att'y Gen., Office of Legal Counsel, to the Att'y Gen., Authority to Use Military Force in Libya 7, I4 (Apr. I, 20II) [hereinafter Krass Memorandum], available at http://www.justice.gov/olc/20II/authority -military-use-in-libya.pdf.

4 Compare, e.g., Edwin Meese III \& Todd Gaziano, Obama's Abuse of Power, WAsh. Post, Jan. 6, 20I2, at $\mathrm{AI} 7$, available at http://www.washingtonpost.com/opinions/obamas-recess -appointaments-are-unconstitutional/20I2/oI/o5/gIQAnWRfdP_story.html ("[F]or almost 90 years the executive branch has generally agreed that a recess as recognized by the Senate of at least nine to Io days is necessary before the president can fill any vacancies with a recess appointment."), with Memorandum Opinion from Virginia A. Seitz, Assistant Att'y Gen., Office of Legal Counsel, to the Counsel to the President, Lawfulness of Recess Appointments During a Recess of the Senate Notwithstanding Periodic Pro Forma Sessions 6-7 (Jan. 6, 20I2), available at http://www.justice.gov/olc/2012/pro-forma-sessions-opinion.pdf (relying on the "recess appointment practice of past Presidents" and "significant (albeit not uniform) evidence that the Executive Branch's view that recess appointments during intrasession recesses are constitutional has been accepted by Congress and its officers" to show that intrasession recess appointments are constitutional)

5 The only general treatment of the subject was written more than twenty-five years ago. See Michael J. Glennon, The Use of Custom in Resolving Separation of Powers Disputes, 64 B.U. L. REV. IO9 (I 984). For discussions of historical practice focused on specific areas, see, for example, Peter J. Spiro, Treaties, Executive Agreements, and Constitutional Method, 79 TEX. L. REV. 96I (200I); and Jane C. Stromseth, Understanding Constitutional War Powers Today: Why Methodology Matters, io6 Yale L.J. 845 (ig96) (reviewing Louis Fisher, Presidential War Power (I995)). 
congressional-executive relations, even though such work has heavily influenced other recent public law scholarship. ${ }^{6}$

Our aim in this Article is to think more systematically about the role of historical practice in discerning the separation of powers. Throughout our analysis, we emphasize four overarching points. First, it is important to identify the reasons why historical practice is invoked in any given separation of powers context. The most common reason appears to be the idea that the cited practice involves the "acquiescence" of one branch in the actions of the other. There is no fixed metric for ascertaining acquiescence, however, and in some contexts the claim of acquiescence is based on nothing more than the absence of a visible objection by one branch to the other's actions. The precise significance of acquiescence also varies considerably from one account to the next. Some claims take it to reflect an interbranch agreement about the legality of the practice in question, and then accord that agreement particular deference as a matter of constitutional interpretation. Other accounts treat acquiescence as a kind of waiver by the nonobjecting branch of its institutional prerogatives; on that view, such a waiver deserves respect either because it has generated certain expectation interests or because it might be embedded within a broader interbranch bargain that would be difficult if not impossible to disentangle. In addition, whether they reflect interbranch agreements or mere waivers, acquiesced-in government practices are sometimes privileged on the theory that they embody wisdom accumulated over time and are unlikely to threaten the basic balance of power between Congress and the Executive.

Second, the concept of institutional acquiescence needs to be tied more closely to the reality of how the political branches actually interact. Claims about acquiescence are typically based on a Madisonian conception of interbranch competition, pursuant to which Congress and the Executive are each assumed to have the tools and the motivation to guard against encroachments on their authority. It has become apparent from political science scholarship, however, that the Madisonian model does not accurately reflect the dynamics of modern congressional-executive relations. It is an especially inapt description of congressional behavior. Although Congress and the President may disagree about particular policies, Congress as a body does not sys-

\footnotetext{
6 For notable examples of such scholarship, see Daryl J. Levinson, Empire-Building Government in Constitutional Law, i 8 HARV. L. REV. 915 (2005); Daryl J. Levinson \& Richard H. Pildes, Separation of Parties, Not Powers, I I 9 HARV. L. ReV. 23 I I (2006); Jide O. Nzelibe \& Matthew C. Stephenson, Complementary Constraints: Separation of Powers, Rational Voting, and Constitutional Design, I23 HARv. L. Rev. 6I7 (2010); Eric A. Posner \& Adrian Vermeule, Constitutional Showdowns, 56 U. PA. L. REV. 99I (2008); and Eric A. Posner \& Adrian Vermeule, The Credible Executive, 74 U. CHI. L. REV. 865 (2007).
} 
tematically seek to protect its prerogatives against presidential encroachment. This indifference is a result of both collective action problems and veto limitations (which make it difficult to enact formal legislation and limit the benefits that individual members can derive from investments in congressional authority), as well as the tendency of individual members to identify more strongly with their political party than with the legislative branch as an institution.

Third, while the descriptive flaws in the Madisonian model do not undermine all claims of institutional acquiescence, they do generate certain insights about when such claims will be more or less defensible. One insight is that claims of executive acquiescence and claims of legislative acquiescence should not be treated the same way. The Madisonian model is most inapt as applied to Congress, and so its flaws threaten claims of congressional acquiescence more than claims of executive acquiescence. It can still be appropriate, though, to infer acquiescence - whether taken to mean interbranch agreement or institutional waiver - from executive nonobjection to legislative action. In addition, the difficulties with the Madisonian model on the legislative side argue not so much for rejecting the idea of acquiescence altogether as for being more cautious about treating apparent legislative inaction as acquiescence, and for looking beyond formal enactments when assessing whether any given case actually involves acquiescence or nonacquiescence. Finally, for both legislative and executive acquiescence, inferences of interbranch agreement or waiver are likely to be more defensible when the practice in question is not only longstanding but also the product of bipartisan choices. In those circumstances, there is less reason to worry that institutional acquiescence might simply be the product of political party loyalty or an attempt to bind one's successor to a novel interpretation.

Fourth, any attempt to evaluate or even describe the role of historical practice in the separation of powers area must be sensitive to the institutional context in which the question arises. In particular, it is vital to distinguish between situations when judicial review is a realistic possibility and situations when it is not. When it is not, interactions between the political branches will, as a practical matter, determine the separation of powers. The proper role of past practice in such nonjudicial determinations presents questions that are different in important respects from the proper role of past practice in litigated controversies. Still, the two scenarios are connected in that the availability of judicial review may be affected by whether the courts think the nonjudicial mechanisms are likely to generate normatively acceptable constitutional outcomes. In that respect, by calling into question the descriptive accuracy of the Madisonian model - a model that has been at least as influential with courts as with scholars - this Article provides a potential justification for greater judicial review of separation of powers disputes. 
This Article develops each of these four general points, with the aim of better understanding the role of historical practice in the separation of powers context. There are of course other approaches to constitutional interpretation, and we do not attempt here a freestanding defense of relying on historical practice as against any of those other approaches. Instead, we accept that arguments from history are and are likely to remain - pervasive in the separation of powers context. In light of that reality, our goal is to provide a conceptual framework for analyzing and evaluating historical practice-based arguments relating to the constitutional separation of powers.

We note one caveat before proceeding: our consideration of the role of historical practice is limited to the constitutional separation of powers, and in particular to issues of executive and legislative power. We acknowledge, of course, that arguments based on past practice are not limited to that context. For example, arguments from "tradition" are common, and sometimes highly controversial, in certain individual rights controversies. ${ }^{7}$ In the separation of powers area, however, the focus is solely on governmental practices, not general social practices or beliefs. Relying on past practice in this area also does not typically raise concerns about the oppression of minorities or other disadvantaged groups the way that it does in some individual rights areas. ${ }^{8}$ To be sure, past governmental practices have played an important role in areas other than the separation of powers. The Supreme Court has relied heavily on such practices, for example, in construing the scope of Congress's legislative authority under the Copyright Clause. ${ }^{9}$ Historical practice in the separation of powers context is distinctive, however, in that it generally involves conduct by one political branch implicat-

\footnotetext{
7 See generally Rebecca L. Brown, Essay, Tradition and Insight, I03 YALE L.J. I77 (I993); William N. Eskridge, Jr., Sodomy and Guns: Tradition as Democratic Deliberation and Constitutional Interpretation, 32 HARV. J.L. \& PUB. POL'Y 193 (2009); Kim Forde-Mazrui, Tradition as Justification: The Case of Opposite-Sex Marriage, 78 U. CHI. L. REV. 28I (20I I); Glennon, supra note 5, at I44; Michael J. Perry, The Authority of Text, Tradition, and Reason: A Theory of Constitutional "Interpretation," 58 S. CAL. L. REV. 55 I (I985).

8 See, e.g., Henry P. Monaghan, Presidential War-Making, 50 B.U. L. REv. I9, 3I (1970) (distinguishing between relying on history in a way that would "freeze forever the scope of a constitutional guarantee framed in terms of individual liberty" and relying on it for "the distribution of political power between the legislative and executive branches"); Cass R. Sunstein, Burkean Minimalism, I05 MICH. L. REV. 353, 400 (2006) ("Under some constitutional provisions, above all the Equal Protection Clause, the Burkean [tradition-based] approach is hard or perhaps impossible to square with entrenched understandings in American constitutional law . . ..").

9 U.S. ConsT. art. I, § 8, cl. 8; see also Golan v. Holder, I32 S. Ct. 873, 885-87 (2012) (relying on historical practice in support of congressional power to grant copyright protection to works in the public domain); Eldred v. Ashcroft, 537 U.S. I86, 200-04 (2003) (invoking historical practice in support of congressional power to extend copyrights). To take another example, when deciding whether particular state laws are preempted, the Supreme Court sometimes considers whether the laws fall within "fields of traditional state regulation." E.g., N.Y. State Conference of Blue Cross \& Blue Shield Plans v. Travelers Ins. Co., 5 I 4 U.S. 645, 655 (I 995).
} 
ing the interests and prerogatives of the other. Moreover, judicial review of separation of powers issues is often more limited and infrequent than in other areas, making the role of historical practice potentially more significant. We are not claiming that there are no similarities between arguments from historical practice in the separation of powers context and such arguments in other areas. Rather, our point is that the differences are sufficient for us to focus exclusively on the separation of powers area. We take no position on whether our conclusions apply elsewhere.

Part I of this Article describes the widespread reliance on historical practice - in academic scholarship, judicial opinions, and government argumentation - in support of claims about the separation of powers. It also situates questions about the role of historical practice within broader debates about constitutional interpretation and judicial review. Part II unpacks the concept of institutional acquiescence as it is commonly invoked in the separation of powers area. It argues that the concept often rests on assumptions about congressional-executive relations that do not reflect actual institutional behavior. Part III considers the implications of this analysis for the historical-gloss method of constitutional interpretation and suggests ways in which historical practice can still be relevant in thinking about the separation of powers despite the problems associated with claims of acquiescence. Part IV presents three case studies - concerning war powers, congressionalexecutive agreements, and removal of executive officers - to illustrate how arguments based on historical practice have played out in particular contexts and also to highlight the difficulties associated with relying on institutional acquiescence.

\section{HistoricAl PRACTICE AND CONSTITUTIONAL INTERPRETATION}

In this Part, we first show that arguments based on historical practice are common in controversies relating to the separation of powers, in both litigation and nonlitigation contexts. Then, in an effort to better understand these arguments, we explain how they fit within the spectrum of approaches to constitutional interpretation and judicial review.

\section{A. Prevalence of the Historical Gloss Argument}

Within the separation of powers area, historical practice is most commonly invoked in connection with debates over the scope of presidential power. Unlike the extensive list of powers granted to Congress in Article I, the text of the Constitution provides relatively little guid- 
ance about the scope of presidential authority. The first sentence of Article II provides that "[t]he executive Power shall be vested in a President of the United States of America,"10 but there is substantial debate over whether and to what extent this clause conveys substantive authority. ${ }^{11}$ The President is made the Commander in Chief of the armed forces, but the text does not specify what authorities accompany this status. ${ }^{12}$ Most of the few remaining powers listed in Article II are shared with the Senate. For example, the President is given the power to make treaties, but only with the advice and consent of two-thirds of the senators present. ${ }^{13} \mathrm{He}$ also has the power to appoint U.S. ambassadors, but only with the approval of a majority of the Senate. ${ }^{14} \mathrm{Ar}-$ ticle II further states that the President is to receive foreign ambassadors and to take care that the laws are faithfully executed, but those provisions appear to impose obligations, not to convey authority. ${ }^{15}$

Responding in part to this limited textual guidance, Justice Frankfurter emphasized the importance of historical practice to the interpretation of presidential power in his concurrence in the Youngstown steel seizure case. As he put it:

[A] systematic, unbroken, executive practice, long pursued to the knowledge of the Congress and never before questioned, engaged in by Presidents who have also sworn to uphold the Constitution, making as it were such exercise of power part of the structure of our government, may be treated as a gloss on "executive Power" vested in the President by $\S$ I of Art. II. ${ }^{16}$

With some variations, the Supreme Court, executive branch lawyers, and academic commentators have all endorsed the significance of such practice-based "gloss."17

10 U.S. CONST. art. II, § I, cl. I.

11 Compare, e.g., Saikrishna B. Prakash \& Michael D. Ramsey, The Executive Power over Foreign Affairs, I i YALE L.J. 23I, 234 (200I) (arguing that the Article II Vesting Clause is a source of substantive presidential authority), with Curtis A. Bradley \& Martin S. Flaherty, Executive Power Essentialism and Foreign Affairs, IO2 MICH. L. REV. 545, 55 I-52 (2004) (arguing that the Vesting Clause is not a source of substantive presidential authority). For a classic treatment of the basis and scope of presidential power, see Henry P. Monaghan, The Protective Power of the Presidency, 93 Colum. L. ReV. I (I993).

12 See U.S. Const. art. II, § 2, cl. I; see also Youngstown Sheet \& Tube Co. v. Sawyer, 343 U.S. 579, 64I (1952) (Jackson, J., concurring) ("These cryptic words [of the Commander in Chief Clause] have given rise to some of the most persistent controversies in our constitutional history."),

13 See U.S. CONST. art. II, § 2, cl. 2.

14 Id.

15 See id. art. II, § 3 .

16 Youngstown, 343 U.S. at 610-I I (Frankfurter, J., concurring).

17 For Supreme Court decisions, see, for example, Mistretta v. United States, 488 U.S. 36 I (I989), in which the Court stated, "'traditional ways of conducting government ... give meaning' to the Constitution. Our 200-year tradition of extrajudicial service is additional evidence that the doctrine of separated powers does not prohibit judicial participation in certain extrajudicial activity." Id. at 40 I (citation omitted) (quoting Youngstown, 343 U.S. at 6 1о (Frankfurter, J., concur- 
Historical practice is also an important component of the canonical three-tiered framework for assessing presidential power that Justice Jackson articulated in his own Youngstown concurrence. Under that framework, the President's power is at its zenith when supported by express or implied congressional authorization, at its nadir when expressly or implicitly opposed by Congress, and in an intermediate "zone of twilight" when Congress has neither supported nor opposed presidential action. ${ }^{18}$ That intermediate zone, Justice Jackson explained, is one in which the President and Congress "may have concurrent authority, or in which its distribution is uncertain."19 Historical practice is especially pertinent in cases arising in that zone. As Justice Jackson noted, congressional inaction in the face of presidential activity "may sometimes, at least as a practical matter, enable, if not invite, measures on independent presidential responsibility." 20

Historical practice also has been relied upon to support a claim of implicit congressional authorization or opposition for purposes of the first and third categories in Justice Jackson's framework. In Dames $\mathcal{E}$ Moore v. Regan, for example, the Supreme Court found that a presidential suspension and transfer of claims against Iran to a new international tribunal was supported by congressional acquiescence in light of the long history of executive claims settlement and Congress's general support for such actions. ${ }^{21}$ Relatedly, historical practice can help determine the reach of a congressional authorization or opposition that, while explicit, is ambiguous in scope. In Hamdi v. Rumsfeld, for example, a plurality of the Court interpreted Congress's Authorization

ring)). Also see Dames \& Moore v. Regan, 453 U.S. 654 (I98I), in which the Court noted, "[p]ast practice does not, by itself, create power, but 'long-continued practice, known to and acquiesced in by Congress, would raise a presumption that the [action] had been [taken] in pursuance of its consent....' Id. at 686 (alteration in original) (quoting United States v. Midwest Oil Co., 236 U.S. 459, 474 (I9I5)). For executive branch reasoning, see, for example, the Krass Memorandum, supra note 3: "[U]nder 'the historical gloss on the "executive Power" vested in Article II of the Constitution,' the President bears the 'vast share of responsibility for the conduct of our foreign relations...'”Id. at 6 (quoting Am. Ins. Ass'n v. Garamendi, 539 U.S. 396, 4I4 (2003)). For academic commentary, see the materials cited and discussed in the case studies in Part IV, pp. 46I-85. See also William Howard Taft, Our Chief Magistrate and His Powers i 35 (I9I6) ("Executive power is sometimes created by custom, and so strong is the influence of custom that it seems almost to amend the Constitution.").

18 See Youngstown, 343 U.S. at 635-38 (Jackson, J., concurring).

19 Id. at 637 .

20 Id.; see also Martin S. Flaherty, The Future and Past of U.S. Foreign Relations Law, LAW \& CONTEMP. Probs., Autumn 2004, at I69, I83 (describing Justice Frankfurter's practice-based approach as "complementary" to Justice Jackson's framework).

21 See 453 U.S. at $677-88$; see also Garamendi, 539 U.S. at 4I 5 ("Given the fact that the practice goes back over 200 years, and has received congressional acquiescence throughout its history, the conclusion '[t]hat the President's control of foreign relations includes the settlement of claims is indisputable." (quoting United States v. Pink, 3I5 U.S. 203, 240 (I942) (Frankfurter, J., concurring))). 
for Use of Military Force issued after the September i I terrorist attacks as conferring the authority to detain enemy combatants captured in Afghanistan, in part because Presidents had long detained combatants in military operations. ${ }^{22}$

Invocations of historical practice are particularly common in constitutional controversies implicating foreign relations. In United States v. Curtiss-Wright Export Corp., for example, the Supreme Court upheld a congressional delegation of authority to the President to criminalize arms sales to countries involved in a conflict in Latin America, based in part on the fact that Congress had already established a pattern of delegating broad authority to the President in the foreign affairs area. ${ }^{23}$ As discussed in section IV.B, a frequent argument in support of the constitutionality of "executive agreements" (that is, binding international agreements concluded by the President without obtaining the advice and consent of two-thirds of the Senate) is the fact that Presidents have long concluded such agreements. ${ }^{24}$ Similarly, in assessing whether Presidents have the constitutional authority to terminate treaties without obtaining congressional consent, courts and commentators have looked at the historical practice of treaty terminations. ${ }^{25}$

Relatedly, historical practice is frequently invoked in debates over the wartime and national security powers of the President. For exam-

22 See 542 U.S. 507, 5 I9 (2004) (plurality opinion) ("Because detention to prevent a combatant's return to the battlefield is a fundamental incident of waging war, in permitting the use of 'necessary and appropriate force,' Congress has clearly and unmistakably authorized detention in the narrow circumstances considered here." (quoting Authorization for Use of Military Force, Pub. L. No. 107-40, § 2(a), I I5 Stat. 224, 224 (codified at 50 U.S.C. § I54I (2006)))); see also, e.g., Zemel v. Rusk, 38I U.S. I, 9 (I965) ("The use in the I926 Act of language broad enough to permit executive imposition of area restrictions, after the Executive had several times in the recent past openly asserted the power to impose such restrictions under predecessor statutes containing substantially the same language, supports the conclusion that Congress intended in 1926 to maintain in the Executive the authority to make such restrictions.").

23 See 299 U.S. 304, 327-28 (I936) ("A legislative practice such as we have here, evidenced not by only occasional instances, but marked by the movement of a steady stream for a century and a half of time, goes a long way in the direction of proving the presence of unassailable ground for the constitutionality of the practice, to be found in the origin and history of the power involved, or in its nature, or in both combined.").

24 See infra section IV.B, pp. 468-76.

25 See, e.g., David Gray Adler, The Constitution and the Termination of Treaties I49-207 (Harold Hyman \& Stuart Bruchey eds., I986); Memorandum from John C. Yoo, Deputy Assistant Att'y Gen., and Robert J. Delahunty, Special Counsel, to John Bellinger, III, Senior Assoc. Counsel to the President and Legal Adviser to the Nat'l Sec. Council, Auth. of the President to Suspend Certain Provisions of the ABM Treaty 9 (Nov. I5, 200I) ("The executive branch has long held the view that the President has the constitutional authority to terminate treaties unilaterally, and the legislative branch seems for the most part to have acquiesced in it."); see also Goldwater v. Carter, 6I 7 F.2 697,706 (D.C. Cir.) ("There is much debate among the historians and scholars as to whether in some instances the legislature has been involved at all; they are agreed that, when involved, that involvement with the President has taken many different forms."), vacated on other grounds, 444 U.S. 996 (I979). 
ple, once the warrantless surveillance program secretly initiated by the Bush Administration after the September I I terrorist attacks became public, the Administration relied heavily on claims about historical practice to defend the program. ${ }^{26}$ Another example, noted above, is the Obama Administration's reliance on historical practice in claiming that it had the constitutional authority to conduct military operations in Libya without congressional authorization. ${ }^{27}$

Appeals to historical practice are not confined to matters relating to foreign affairs or war powers, however. For example, the Supreme Court has emphasized longstanding presidential practice when considering when the President's "pocket veto" (that is, failure to sign a bill before Congress recesses) should be deemed to operate. ${ }^{28}$ Similarly, in concluding that the President's pardon power extended to a contemptof-court conviction, the Court reasoned that "long practice under the pardoning power and acquiescence in it strongly sustains the construction it is based on." 29 Moreover, arguments about the scope of both the "executive privilege" (concerning the ability to withhold internal executive branch communications from the other branches of government) and the "legislative privilege" (concerning, among other things, the internal powers of the two houses of Congress) are commonly informed by historical practice. ${ }^{30}$ Yet another example, noted in the Introduction, is the recent debate over the scope of the President's power to make "intrasession" recess appointments of federal officials. ${ }^{31}$

Although historical practice is most frequently invoked in favor of executive authority, it is also sometimes treated as a source of congressional power. Consider, for example, Hamdan v. Rumsfeld, in which the Supreme Court invalidated the military commission system established by President Bush after the September I I terrorist attacks on

26 See Memorandum from Alberto R. Gonzales, Att'y Gen., to Hon. William H. Frist, Majority Leader, U.S. Senate, Legal Authorities Supporting the Activities of the National Security Agency Described by the President 7 (Jan. I9, 2006), available at http://www.justice.gov/opa /whitepaperonnsalegalauthorities.pdf (“[A] consistent understanding has developed that the President has inherent constitutional authority to conduct warrantless searches and surveillance within the United States for foreign intelligence purposes.").

27 See Krass Memorandum, supra note 3, at 6-9.

28 See The Pocket Veto Case, 279 U.S. 655, 689 (1929) ("Long settled and established practice is a consideration of great weight in a proper interpretation of constitutional provisions of this character.").

29 Ex parte Grossman, 267 U.S. 87, I I8-I9 (I925).

30 See, e.g., Josh Chafetz, Democracy's Privileged Few ro-i9 (2007); Archibald Cox, Executive Privilege, I22 U. PA. L. REV. I383, I384-I405 (I974); Peter M. Shane, Legal Disagreement and Negotiation in a Government of Laws: The Case of Executive Privilege Claims Against Congress, 7 I MINN. L. REV. 46I, 466-84 (I987).

31 See supra p. 4I3; see also Recess Appointments During an Intrasession Recess, I6 Op. O.L.C. I5, I6 (I 992) ("Past practice is consistent with exercise of the recess appointment power during an intrasession recess of eighteen days."). 
the ground that the system violated statutory requirements. ${ }^{32}$ The Court never specifically explained why it thought Congress had acted within its constitutional authority in imposing the requirements, but it appeared to place significant weight on the historical pedigree of the statutory provisions at issue. ${ }^{33}$ Scholars arguing that Congress has broad authority to limit the President's war authority have likewise relied heavily on historical practice. ${ }^{34}$

The absence of historical practice supporting a particular exercise of executive power can also favor Congress. In Medellín v. Texas, for example, the Court considered the effect of a presidential memorandum providing that the United States would comply with a decision of the International Court of Justice "by having State courts give effect to the decision." 35 In holding that the memorandum could not impose a legally binding obligation on state courts to entertain claims based on the international court's decision, the Court stressed the novelty of the memorandum. ${ }^{36}$ The Court allowed that, "if pervasive enough, a history of congressional acquiescence can be treated as a 'gloss on "Executive Power" vested in the President by $\S$ I of Art. II."'37 The memorandum, however, had no such history to draw upon: "The President's Memorandum is not supported by a 'particularly longstanding practice' of congressional acquiescence, but rather is what the United States itself has described as "unprecedented action." "38 As a result, the Court concluded that historical practice had not altered the background proposition that "[t]he responsibility for transforming an inter-

32 See 548 U.S. 557,564 (2006).

33 See id. at 592 \& n.22 (relying on Article 2I of the Uniform Code of Military Justice, enacted in I950, "the language of which is substantially identical to the old Article I5 [of the Articles of War] and was preserved by Congress after World War II"); see also id. at 638 (Kennedy, J., concurring in part) ("In this case, as the Court observes, the President has acted in a field with a history of congressional participation and regulation." (emphasis added)).

34 See, e.g., David J. Barron \& Martin S. Lederman, The Commander in Chief at the Lowest Ebb - A Constitutional History, I2 I HARV. L. REV. 94I (2008) (examining in detail historical practice relating to congressional regulation of issues relating to war); David J. Barron \& Martin S. Lederman, The Commander in Chief at the Lowest Ebb - Framing the Problem, Doctrine, and Original Understanding, I I HARV. L. REV. 689 (2008) (same). Yet another example is the congressional contempt power, which has no explicit basis in the constitutional text (beyond the Rules of Procedure Clause) but which is broadly accepted today, in part because of longstanding practice. See ChAFETz, supra note 30 , at 207-35.

35552 U.S. 49I, 498 (2008) (quoting Memorandum from President George W. Bush for the Att'y Gen., Compliance with the Decision of the International Court of Justice in Avena (Feb. 28, 2005)) (internal quotation marks omitted).

36 See id. at 532.

37 Id. at 53 I (quoting Dames \& Moore v. Regan, 453 U.S. 654, 686 (I98I)).

38 Id. at 532 (citation omitted); see also Trevor W. Morrison, Constitutional Alarmism, I24 HARV. L. REV. I688, I705-06 (20I I) (reviewing BRUCE ACKERMAN, The DECLINE AND FALL OF THE AMERICAN REPUBLIC (20IO)) (discussing this aspect of Medellin). 
national obligation arising from a non-self-executing treaty into domestic law falls to Congress." 39

That said, courts do not always treat the presence or absence of longstanding practice as dispositive. Probably the most famous counterexample is INS v. Chadha. ${ }^{40}$ In that case, the Court held that a "legislative veto" provision enacted by Congress was unconstitutional because it allowed Congress to engage in a legislative act (overturning exercises of the Attorney General's statutorily delegated authority to suspend deportation) without resort to the bicameralism and presentment process for legislation specified in Article I. ${ }^{41}$ The Court reached this conclusion even though, as Justice White pointed out in dissent, Congress had enacted hundreds of legislative veto provisions since the I930s. ${ }^{42}$ Believing that the unconstitutionality of the provision was clear, the Court dismissed the historical practice, noting that "[c]onvenience and efficiency are not the primary objectives - or the hallmarks - of democratic government and our inquiry is sharpened rather than blunted by the fact that congressional veto provisions are appearing with increasing frequency in statutes which delegate authority to executive and independent agencies." ${ }^{43}$ The Court also noted, however, that numerous Presidents had expressed constitutional concerns about the legislative veto. ${ }^{44}$

Resort to historical practice, then, is a significant though not entirely consistent theme in both judicial and nonjudicial arguments about the Constitution's separation of powers. ${ }^{45}$ That is not to say, of course, that such arguments are straightforward. One recurring complication

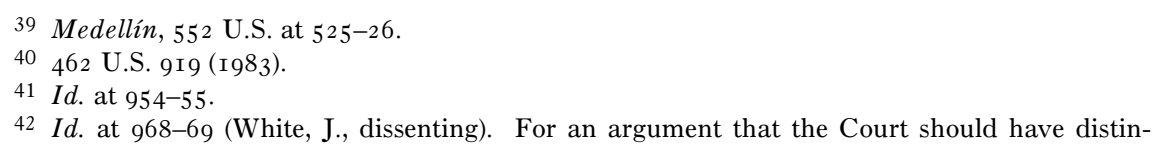
guished between "[u]se of the veto as an instrument of the continuing political dialogue between President and Congress" and "its use to control, in random and arbitrary fashion, those matters customarily regarded as the domain of administrative law," see Peter L. Strauss, Was There a Baby in the Bathwater? A Comment on the Supreme Court's Legislative Veto Decision, I983 DUKE L.J. 789, 79I-92.

43 Chadha, 462 U.S. at 944.

44 See id. at 942 n.I3 ("I I Presidents, from Mr. Wilson through Mr. Reagan, who have been presented with this issue have gone on record at some point to challenge congressional vetoes as unconstitutional."); see also Steven G. CAlabresi \& Christopher S. Yoo, The Unitary ExECUTIVE I2 (2008) ("[A] long line of presidents stretching back to Woodrow Wilson challenged the legislative veto as an impermissible legislative interference with executive power.”).

45 Although this Article is primarily focused on issues of executive and legislative authority, historical practice is also potentially relevant to the scope of judicial authority, and, relatedly, the scope of judicial independence from political-branch control. See, e.g., Charles G. Geyh, Judicial Independence, Judicial Accountability, and the Role of Constitutional Norms in Congressional Regulation of the Courts, 78 IND. L.J. I53, I57 (2003) ("To understand judicial independence and its limits, then, we must look beyond 'doctrinal' independence as divined by courts, and examine the historical development of 'customary' independence as it has emerged in Congress."). 
is the issue of scope. Whether a current action is supported by past practice often turns on the scope of the practice. If the current action is precisely analogous to past practice, and if the past practice is supported by consensus, disputes are unlikely to arise. But when there are disputes, they are likely to focus on how to characterize the practice in question. Difficult as those questions may be, they are not unique to arguments based on past governmental practice. Any practice- or precedent-based approach naturally must confront questions about how to specify the scope of the past practice or precedent. That exercise can include normatively freighted threshold issues like selecting the level of generality at which to define the past practice. ${ }^{46}$ We do not minimize those challenges. Because they are not specific to the historical gloss method of constitutional interpretation, however, we do not dwell on them here.

In the next section, we consider the relationship between historical practice-based arguments and broader debates about constitutional theory and judicial review.

\section{B. Constitutional Theory and Judicial Review}

Any consideration of arguments from historical practice inevitably implicates debates about constitutional interpretation on the one hand, and the role of the judiciary (or other constitutional interpreter) on the other. Before assessing the use of historical practice on its own terms, therefore, it is useful to specify its relationship to those other debates.

I. Constitutional Theory. - The extent to which an interpreter will be willing to credit arguments from historical practice will turn in part on the interpreter's overall approach to constitutional interpretation. A strict originalist, for example, may grant considerable weight to historical practice in the early years of the nation insofar as it offers evidence of what was understood or settled by the Founding generation, ${ }^{47}$ but may resist relying on later practices, especially if they de-

46 See, e.g., Richard Craswell, Do Trade Customs Exist?, in The JuRISPRUdential FounDATIONS OF CORPORATE AND COMmercial LAW i i8, i22 (Jody S. Kraus \& Steven D. Walt eds., 2000) ("[A]ny history of prior decisions will always underdetermine the possible patterns that might be ascribed to that history."); Martin S. Flaherty, Post-Originalism, 68 U. CHI. L. ReV. IO89, iro5 (200I) (reviewing DAvid P. CuRrie, The Constitution in Congress: The JEFFERSONIANS, I8OI-I829 (2000)) ("As a theoretical matter, custom has its own problems. Not least among these are the questions of what counts as the relevant custom, at what level of generality, and for how long.").

47 James Madison famously expressed the view that some aspects of constitutional meaning would be "liquidated" or "fixed" through early practice. See THE FEDERAlist No. 37, at 225 (James Madison) (Clinton Rossiter ed., 2003) (stating that the meaning of the Constitution, like that of all laws, would be "liquidated and ascertained by a series of particular discussions and adjudications"). The Supreme Court has also endorsed this proposition. See Myers v. United States, 272 U.S. 52, I75 (I926) ("[A] contemporaneous legislative exposition of the Constitution when the founders of our Government and framers of our Constitution were actively participating in public 
part from what would otherwise appear to be the understandings of those involved in the Constitution's ratification. ${ }^{48}$ Instead, the strict originalist is likely to treat arguments based on such practices the way the district court in Youngstown treated the government's reliance on past presidential seizures of property - as an invocation of "repetitive, unchallenged, illegal acts" that cannot "sanctify those committed thereafter." 49 To be sure, judges commonly associated with originalism do sometimes take account of post-Founding-era historical practice when addressing separation of powers issues, ${ }^{50}$ but they do not typically provide originalist justifications for doing so.

That said, there are practice-based arguments that might appeal to some originalists. It can be argued, for example, that the way in which the Constitution has operated over time is evidence of how it was intended to operate. Although not an originalist, Justice Frankfurter expressed something like this idea in his concurrence in Youngstown: "The Constitution is a framework for government. Therefore the way the framework has consistently operated fairly establishes that it has operated according to its true nature." ${ }_{1}$ Moreover, there are less strict versions of originalism that are likely to be more receptive to historical practice. For example, a "translation"-style originalism, which allows new factual circumstances to alter how the Constitution is applied, might look to patterns of historical practice to help define the permissible boundaries of constitutional change. ${ }^{52}$ Similarly, Professor Jack Balkin's idea of "framework originalism," which "views the Constitution as an initial framework for governance

affairs, acquiesced in for a long term of years, fixes the construction to be given its provisions.”); Stuart v. Laird, 5 U.S. (I Cranch) 299, 309 (I803) ("[P]ractice and acquiescence under it for a period of several years, commencing with the organization of the judicial system, affords an irresistible answer, and has indeed fixed the construction.").

48 See, e.g., Michael C. Dorf, Integrating Normative and Descriptive Constitutional Theory: The Case of Original Meaning, 85 GEO. L.J. I765, I766 (1997) (describing strict originalism as holding that "any departure from the understandings of those discrete periods robs constitutional interpretation of its claim to legitimacy").

49 Youngstown Sheet \& Tube Co. v. Sawyer, I03 F. Supp. 569, 575 (D.D.C. I952); see also, e.g., Powell v. McCormack, 395 U.S. 486, 546-47 (I969) ("That an unconstitutional action has been taken before surely does not render that same action any less unconstitutional at a later date.”).

50 For example, Justice Scalia is a proponent of originalism, see Antonin Scalia, Originalism: The Lesser Evil, 57 U. CIN. L. REV. 849 (I989), but he nevertheless takes account of postFounding historical practice, see, e.g., Stern v. Marshall, I3I S. Ct. 2594, 262 I (20I I) (Scalia, J., concurring) ("[A]n Article III judge is required in all federal adjudications, unless there is a firmly established historical practice to the contrary." (second emphasis added)).

51 Youngstown Sheet \& Tube Co. v. Sawyer, 343 U.S. 579, 610 (I952) (Frankfurter, J., concurring).

52 See generally Larry Kramer, Fidelity to History - And Through It, 65 FORDHAM L. REV. I627, I638 (I997) ("[T]o conceive the Constitution as a dynamic framework of evolving institutions and restraints makes history central to the interpretive enterprise."); Lawrence Lessig, Fidelity and Constraint, 65 FORDHAM L. REV. I365 (I997) (arguing for translation-style originalism); Lawrence Lessig, Fidelity in Translation, 7 I TEX. L. REV. I 65 (I993) (same). 
that sets politics in motion and must be filled out over time through constitutional construction," is also compatible with reliance on historical practice. ${ }^{53}$

Nevertheless, even if some versions of originalism are compatible with practice-based arguments, various nonoriginalist approaches are likely to be more receptive to such arguments. In particular, reliance on historical practice fits well with the Burkean preference for longstanding traditions and understandings. ${ }^{54}$ To a Burkean, historical practice is important in part because of its potential to reflect collective wisdom generated by the judgments of numerous actors over time. ${ }^{55}$ Reliance on historical practice also fits well with the somewhat related idea of "common law constitutionalism," which involves an incremental interpretation of the Constitution in light of both judicial precedent and tradition. ${ }^{56}$ Like Burkeanism, this approach is deferential to the "accumulated wisdom of many generations" and to judgments that "have been tested over time, in a variety of circumstances, and have been found to be at least good enough." 57 Both of these approaches, like translation-style originalism, also allow for the possibility that constitutional law can adapt over time to changing circumstances. ${ }^{58}$

Similarly, a focus on the historical practice of the political branches is consistent with some of the increased scholarly emphasis in recent years on constitutional law developed outside the courts. ${ }^{59}$ Parts of that literature focus on "popular constitutionalism" — that is, the con-

53 Jack M. Balkin, Framework Originalism and the Living Constitution, I03 Nw. U. L. REV. 549,550 (2009).

54 See generally Edmund Burke, Reflections on the Revolution in France (J.G.A. Pocock ed., I987) (I790). For discussions of Burkean approaches to constitutional interpretation, see generally, for example, Sunstein, supra note 8; and Thomas W. Merrill, Bork v. Burke, I9 HARV. J.L. \& PUB. POL'Y 509 (I996).

55 See BuRke, supra note 54, at 76 ("We are afraid to put men to live and trade each on his own private stock of reason, because we suspect that this stock in each man is small, and that the individuals would do better to avail themselves of the general bank and capital of nations and of ages."); Sunstein, supra note 8, at $37 \mathrm{I}$.

56 For an argument in favor of this approach to constitutional interpretation, see generally David A. Strauss, Common Law Constitutional Interpretation, 63 U. CHI. L. REV. 877 (I996). For a critique, see generally Adrian Vermeule, Essay, Common Law Constitutionalism and the Limits of Reason, I07 COLUM. L. REV. I482 (2007).

57 Strauss, supra note 56 , at 892 .

58 See id. at 905 (arguing that common law constitutionalism helps explain why "[t]he most important changes to the Constitution - many of them, at least $-\ldots$ have come about either through changes in judicial decisions, or through deeper changes in politics or in society"); Ernest Young, Rediscovering Conservatism: Burkean Political Theory and Constitutional Interpretation, 72 N.C. L. REV. 619, 664 (1994) (explaining that, under a Burkean approach, "institutions become effective in meeting the needs of society through a continuing process of adaptation that may or may not be consistent with the original intentions of the founders").

59 See generally Larry D. Kramer, The PeOple Themselves (2004); Mark Tushnet, TAKing the Constitution AwAy From the Courts (ig99); Keith E. WhitTington, CONSTITUTIONAL CONSTRUCTION (I999). 
stitutional views of "the people," including social movements organized around political, social, and cultural ideas expressed in constitutional terms. ${ }^{60}$ But other parts, more relevant here, stress the importance of governmental practices to constitutional meaning and development. ${ }^{61}$

Historical practice-based arguments also overlap with approaches to constitutional law that emphasize particularly decisive moments in history, such as Professor Bruce Ackerman's account of constitutional "moments" and Professors Eric Posner and Adrian Vermeule's account of "constitutional showdowns." 22 These descriptions of constitutional law are similar to practice-based arguments in that both place special weight on the actions of the political branches. However, these types of accounts tend to focus on critical turning points, whereas invocations of the historical gloss method tend to emphasize long-term accretions of practice. ${ }^{63}$

There is an even stronger connection between historical practicebased arguments and those that rely on precedent in judicial (or, for that matter, executive ${ }^{64}$ ) decisionmaking. Many of the standard values associated with deference to judicial precedent can support deferring to nonjudicial precedent as well. ${ }^{65}$ For example, one justification for adhering to judicial precedent is that it promotes consistency and predictability in the law by protecting reliance interests. ${ }^{66}$ Such interests, however, can presumably arise as a result of governmental practices as well as judicial decisions.

In addition, as with adherence to judicial precedent, deferring to historical practice can serve the value of decisional efficiency. One ar-

60 See generally, e.g., Robert C. Post, The Supreme Court, 2002 Term - Foreword: Fashioning the Legal Constitution: Culture, Courts, and Law, II 7 HARV. L. REv. 4 (2003); Reva B. Siegel, Constitutional Culture, Social Movement Conflict and Constitutional Change: The Case of the De Facto ERA, 94 CAL. L. REV. I323 (2006); Reva B. Siegel, The Supreme Court, 2007 Term Comment: Dead or Alive: Originalism as Popular Constitutionalism in Heller, I2 2 HARV. L. REV. I9I (2008).

61 See, e.g., Stephen M. Griffin, American Constitutionalism 45 (ig96) ("The meaning of most provisions in the Constitution is thus determined in the course of the interaction between the executive and the legislative branches."); WHITTINGTON, supra note 59, at 209-I4 (discussing the role of nonjudicial actors, including political institutions, in constitutional construction).

62 See i Bruce Ackerman, We the People: Foundations 22 (ig9i); Posner \& Vermeule, Constitutional Showdowns, supra note 6, at 997-98; see also Brannon P. Denning \& Glenn H. Reynolds, Constitutional "Incidents": Interpretation in Real Time, 70 TENN. L. REV. $28 \mathrm{I}, 288$ (2003) (recommending the use of "incident analysis" - a technique developed in international law - as a "supplement [to] traditional case analysis" in constitutional analysis).

63 See, e.g., Youngstown Sheet \& Tube Co. v. Sawyer, 343 U.S. 579, 6 10 (1952) (Frankfurter, J., concurring) (referring to "a systematic, unbroken, executive practice, long pursued to the knowledge of the Congress and never before questioned").

64 See generally Trevor W. Morrison, Stare Decisis in the Office of Legal Counsel, i io CoLum. L. REV. I 448 (2010).

65 See Michael J. Gerhardt, Non-Judicial Precedent, 6I VAND. L. REV. 7I3, 764-76 (2008).

66 See Planned Parenthood of Se. Pa. v. Casey, 505 U.S. 833, 855-56 (1992). 
gument made in the stare decisis context is that, "[i]n a large number of situations, a person ... who considers a legal or policy question 'from the ground up' will reach the same conclusion as those who have already considered the question." ${ }_{67}$ If that is generally true, then a presumption of adhering to precedent is more efficient than considering the issue as a matter of first impression every time. To the extent one accepts this efficiency-based argument in favor of stare decisis, it may provide a parallel reason for crediting historical practice. If the practice entrenches a position that the relevant decisionmaker would likely favor even in the absence of that practice, then it is efficient to defer to that practice.

A second efficiency argument relates specifically to the issues of executive power with which the historical gloss approach is most commonly associated. Precisely because the Constitution's textual references to executive power are so spare and because there are relatively few judicial precedents in the area, historical practice may provide the most objective basis for decision. ${ }^{68}$ Eschewing reliance on historical practice, in contrast, may leave the decisionmaker with little basis for resolving the matter at all. This does not necessarily mean that historical practice will yield normatively desirable outcomes. The point is simply that on at least some issues of executive power, it might be exceptionally difficult to reach any reasoned decision without relying on historical practice.

Finally, as in the stare decisis context, reliance on historical practice can enhance the credibility of the decisionmaker. ${ }^{69}$ This is in part because, as noted above, such practice can help the decisionmaker provide a reasoned explanation that is not dependent on the political valence of the controversy in question. In addition, when the decisionmaker is the same actor that is engaging in the practice (for example, when the executive branch is explaining actions that are not subject to judicial review, or the Supreme Court is explaining an interpretation of its own authority), invocations of historical precedent highlight the fact that institutional predecessors have reached the same conclusion, which can help persuade audiences that the conclusion reflects a reasonable constitutional interpretation.

2. Judicial Review. - Some of the arguments in favor of relying on historical practice depend on the identity of the decisionmaker and thus implicate debates over the proper role of the judiciary in particular. Indeed, one way of thinking about arguments from historical

\footnotetext{
67 Mark Tushnet, Legislative and Executive Stare Decisis, 83 NOTRE DAme L. REV. I339, I339-40 (2008).

68 See Morrison, supra note 64, at I495-96 (emphasizing the value of OLC precedents for similar reasons).

69 See id. at $1496-97$.
} 
practice as applied by the courts is that they respect appropriate limits on judicial review, given its "countermajoritarian" character. ${ }^{70}$ The countermajoritarian difficulty is particularly strong when both political branches share a view that is different from the judiciary's, and have held that view for a long time. Judicial deference to the political branches' longstanding practices can blunt those concerns. ${ }^{71}$

There are, moreover, certain areas where the judiciary's proper role is seen as particularly limited. Foreign affairs is a prime example. In that area, as Professor Louis Henkin observed, "courts are less willing than elsewhere to curb the federal political branches, are even more disposed to presume the constitutional validity of their actions and to accept their interpretations of statutes, and have even developed doctrines of special deference to them."72 Reliance on historical practice is one such doctrine, or tactic, of deference in this area. In part, this deference may reflect a recognition that the judiciary would risk being ignored if it adopted a more aggressive posture. But it may also, or alternatively, reflect limitations on the judiciary's expertise and access to information, limitations that are thought to be especially acute in the area of foreign affairs. ${ }^{73}$

More broadly, historical practice arguments are connected to the political question doctrine and other justiciability limitations. Under the modern political question doctrine, courts leave certain legal questions to be resolved by the political branches, based on a consideration of six factors. ${ }^{74}$ The first such factor is whether there is "a textually demonstrable constitutional commitment of the issue to a coordinate political department."75 Determining whether there is such a commitment often depends on an assessment of historical practice. For example, it is generally agreed that the Constitution, by implication from

70 On the countermajoritarian difficulty generally, see ALEXANDER M. BICKEL, THE LEAST DANGEROUS BRANCH I6-23 (I962). For a reconsideration of the countermajoritarian thesis, see BARRY FRIEDMAN, THE WILl OF THE PEOPle (2009). And for a critique of the contention that the Court is in fact "majoritarian," see Richard H. Pildes, Is the Supreme Court a "Majoritarian" Institution?, 2010 SUP. CT. REV. Iо3.

71 See infra section II.A, pp. 433-38.

72 Louis Henkin, Foreign AfFairs ANd the United States Constitution I32 (2d ed. I996). For criticism of this tendency, see Thomas M. FrAnck, POLITICAL Questions /JUDICIAL ANSWERS (I992).

73 See, e.g., Jide Nzelibe, The Uniqueness of Foreign Affairs, 89 IOWA L. REV. 94I, 976 (2004).

74 See Baker v. Carr, 369 U.S. I86, 2 I 7 (I962). The Court has not accorded equal weight to each of the six factors. See, e.g., Vieth v. Jubelirer, 54I U.S. 267, 278 (2004) (plurality opinion) ("These tests are probably listed in descending order of both importance and certainty."); Nixon v. United States, 506 U.S. 224, 228 (I993) (focusing on the first two Baker factors). For a recent decision emphasizing that the political question doctrine is "a narrow exception" to the judiciary's obligation to decide cases, and suggesting that the doctrine may have little application to cases involving the constitutionality of federal statutes, see Zivotofsky ex rel. Zivotofsky v. Clinton, I32 S. Ct. I42I, I427-28 (2OI2).

75 Baker, 369 U.S. at 217 . 
the Ambassador Clauses in Article II, ${ }^{76}$ gives the President exclusive authority to decide whether the United States recognizes particular governments. ${ }^{77}$ The contours of this "recognition power" are debated, however, and that debate is heavily informed by practice. ${ }^{78}$ More generally, dismissals on political question grounds can be understood as a form of judicial underenforcement of the Constitution. ${ }^{79}$ On that understanding, the only difference between political question dismissals and deference to historical practice may be the extent of the deference. In either case, the judiciary places the constitutional answer substantially in the hands of the political branches.

3. The Importance of Ambiguity. - Having situated claims about historical practice among various other forms of constitutional argumentation, and having considered the relationship of such claims to judicial review, we conclude with the observation that in any given context, the role of historical practice is likely to depend on the perceived clarity of other evidence of constitutional meaning. The more an interpreter deems nonpractice evidence like the text and original understanding to be clear, the less likely the interpreter is to credit historical practice that points in a different direction - or, put differently, the more widespread and deeply entrenched the practice must be in order to change the outcome. The opposite proposition also holds: the more an interpreter deems nonpractice materials to be ambiguous or

76 See Restatement (ThiRd) OF the Foreign Relations LaW of the United STATES $\$ 204 \mathrm{cmt}$. a (I987) ("The authority [to recognize foreign governments] is implied in the President's express constitutional power to appoint Ambassadors (Article II, Section 2) and to receive Ambassadors (Article II, Section 3), and his implied power to conduct the foreign relations of the United States."); Robert J. Reinstein, Recognition: A Case Study on the Original Understanding of Executive Power, 45 U. RICH. L. REV. 80I, 8I 2 (20I I) ("The constitutional provision that the President 'shall receive Ambassadors and other public Ministers' is the most often cited source of a plenary executive recognition power and has the longest historical pedigree.”).

77 See, e.g., Banco Nacional de Cuba v. Sabbatino, 376 U.S. 398, 4Io (I964) ("Political recognition is exclusively a function of the Executive.").

78 Compare Brief for the Respondent at I8-24, Zivotofsky, I32 S. Ct. I42 I (No. Io-699) (presenting detailed arguments that "[t]he Executive Branch has consistently exercised sole authority to recognize foreign states, and Congress has acquiesced in that practice," $i d$. at I8), with Petitioner's Reply Brief at 3-20, Zivotofsky, I32 S. Ct. I42 I (No. Io-699) (responding with detailed arguments that "[h]istory [r]efutes the [s]weeping '[r]ecognition [p]ower' [a]sserted by the Respondent," $i d$. at 3 ).

79 See Richard H. Fallon, Jr., Judicially Manageable Standards and Constitutional Meaning, I I9 HARV. L. REV. I274, I306 (2006). One reason why courts may decide to underenforce the Constitution is a sense that for some issues the political branches are better situated to make the relevant constitutional decision. See Rachel E. Barkow, More Supreme than Court? The Fall of the Political Question Doctrine and the Rise of Judicial Supremacy, ro2 CoLUM. L. Rev. 237, 240 (2002) ("Underlying the political question doctrine... is the recognition that the political branches possess institutional characteristics that make them superior to the judiciary in deciding certain constitutional questions."); Kermit Roosevelt III, Aspiration and Underenforcement, II9 HARV. L. REV. F. I93, I97-98 (2006). 
indeterminate, the more likely the interpreter is to rely on historical practice to inform constitutional meaning.

One reason the weight given to historical practice varies inversely with the clarity of other sources is methodological. The very fact that an interpreter deems that materials like the constitutional text and original understanding point clearly in a particular direction makes it less likely that the interpreter will accept an outcome pointing in another direction. One need not be committed to a rigorous program of textualist originalism to agree that if the constitutional text clearly and straightforwardly answers a particular question, the burden of proof required to credit any argument for departing from that answer will - and should - be very heavy. Still, this observation underscores that reliance on historical practice is more compatible with certain styles of constitutional argumentation than with others, and that its role in any given context thus depends in part on an interpreter's general interpretive preferences. It is not a coincidence, then, that the Supreme Court decision most famous for refusing to credit historical practice - INS v. Chadha - was textualist and formalist in its methodology. 80

There is an additional dimension to the connection between textual ambiguity and historical practice. When a constitutional provision's meaning is broadly accepted as clear as a matter of its plain text, that clear meaning is likely to serve as a focal point for the practice of government actors. ${ }^{81}$ Such broad acceptance is most likely to occur for relatively "low-stakes" issues. ${ }^{82}$ In those situations, longstanding practices that substantially diverge from the accepted textual meaning are unlikely to develop. However, historical practice may also affect whether textual materials are perceived as clear or unclear. Moreover, interested parties are more likely to find ambiguity when their political needs demand it, and in such cases arguments from historical practice are more likely to feature prominently. ${ }^{83}$ In other words, constitutional

80 See 462 U.S. 919 (1983).

81 See Daryl J. Levinson, Parchment and Politics: The Positive Puzzle of Constitutional Commitment, I24 HARV. L. REV. 657, 709 (20II); John O. McGinnis, Constitutional Review by the Executive in Foreign Affairs and War Powers: A Consequence of Rational Choice in the Separation of Powers, LAW \& CONTEMP. PROBS., Autumn I 993, at 293, 300-OI.

82 Levinson, supra note $8 \mathrm{I}$, at 709 ("The constitutional text is quite specific on many lowstakes issues, where agreement is more important to most political actors than achieving any particular outcome."); see also Strauss, supra note 56, at 9I6 ("The text matters most for the least important questions.").

${ }^{83} \mathrm{Cf}$. Levinson, supra note 8I, at 7 Io ("[C]ourts and political actors turn to the text to 'formalistically' resolve separation of powers disputes that have low or uncertain stakes but abandon the text for 'functional' analyses of disputes with predictably serious political consequences."). 
law and politics are intertwined in this context, especially when judicial review is unlikely. ${ }^{84}$

\section{INSTITUTIONAL ACQUIESCENCE}

According to many accounts of how historical practice relates to the separation of powers, a practice by one branch of government that implicates the prerogatives of another branch gains constitutional legitimacy only if the other branch can be deemed to have "acquiesced" in the practice over time. Professor Michael Glennon argues, for example, that in order for a practice or custom to reach constitutional significance in this context, three elements must be present: "First, the custom in question must consist of acts; mere assertions of authority to act are insufficient. Second, if a coordinate branch has performed the act, the other branch must have been on notice of its occurrence. Third, the branch placed on notice must have acquiesced in the custom." 85 The first two elements are relatively straightforward and easily justified. The third, acquiescence, is the key. On the view advanced by many, it is what gives otherwise merely unilateral acts legal significance. ${ }^{86}$

In this Part, we first consider the potential meanings of acquiescence as well as the reasons for focusing on it. In some circumstances, acquiescence is treated as evidence of interbranch agreement about the constitutionality of the practice in question. In others, acquiescence is thought to reflect interbranch agreement about the practical workability or acceptability of the practice. And in others, acquiescence is not taken to reflect any particular agreement but is instead treated as a waiver of institutional prerogatives. Having laid out these various understandings and the values associated with them, we then examine

\footnotetext{
84 We consider the relationship between constitutional law and politics in the separation of powers area more fully in a forthcoming essay, see Curtis A. Bradley \& Trevor W. Morrison, Essay, Constitutional Practice as a Constraint on the President, I I3 Colum. L. REV. (forthcoming May 20I3).

85 Glennon, supra note 5, at I34.

86 See, e.g., David J. Bederman, Custom as a Source of LAW ii i (20Io) (noting that for historical practice to inform the interpretation of separation of powers, one must ask "whether the opposing branch in the separation-of-powers struggle has actually accepted or 'acquiesced' in the practice"); HAROLD H. BRUfF, BALANCE OF ForCes 66 (2006) ("Th[e] 'Madisonian' acquiescence doctrine ... requires a full understanding and acceptance on the part of the branches of government . . . before a practice can gloss the Constitution."); Peter J. Spiro, War Powers and the Sirens of Formalism, 68 N.Y.U. L. REV. I338, I356 (I993) (reviewing JOHN HART ELY, WAR AND RESPONSIBILITY (I 993)) ("[T] he other branch must have accepted or acquiesced in the action."); Stromseth, supra note 5, at 880 ("Congress ... must not only be on notice of an executive practice and accompanying claim of authority to act; it also must accept or acquiesce in that practice and claim of authority."); $c f$. Louis Fisher, Constitutional Conflicts Between CONGRESS AND THE PRESIDENT ig (5th rev. ed. 2007) ("Custom is a source of executive power - particularly when Congress fails to challenge and check.").
} 
the assumptions underlying any acquiescence-based approach to historical practice. Drawing on insights from political science, we argue that those assumptions, which rest on an account of the separation of powers similar to the one outlined by James Madison in The Federalist No. 5I, fit poorly with the reality of modern executive-legislative relations.

\section{A. The Meaning and Value of Acquiescence}

Among historical practice-based arguments in the separation of powers area that focus on institutional acquiescence, the concept of acquiescence has been accorded a range of meanings. Concomitantly, there are a variety of reasons why courts and other interpreters privilege acquiescence to historical practices implicating the separation of powers. Some of those reasons can be understood as more focused versions of points made in Part I about the relationship between arguments from historical practice and other approaches to constitutional interpretation. Others are distinctive to the concept of acquiescence itself.

I. Acquiescence as Agreement. - On some accounts, institutional acquiescence reflects an agreement on the part of the acquiescing branch that the actions of the other branch are lawful. ${ }^{87}$ From this perspective, the key interpretive question is whether the political branches share a common understanding of the constitutional question at issue. The most direct evidence on this score is found in the rare instances in which Congress and the executive branch expressly agree that a particular practice is constitutional. To take an example that will be discussed more fully in one of our case studies, Congress in the

87 See, e.g., Dames \& Moore v. Regan, 453 U.S. 654, 680, 686 (I98I) (stating that "[c]rucial to our decision today is the conclusion that Congress has implicitly approved the practice of claim settlement by executive agreement," $i d$. at 680 , and basing that conclusion on "the inferences to be drawn from the character of the legislation Congress has enacted in the area, such as the [International Emergency Economic Powers Act] and the Hostage Act, and from the history of acquiescence in executive claims settlement," $i d$. at 686); Krass Memorandum, supra note 3, at 7 ("This historical practice [relating to war powers] is an important indication of constitutional meaning, because it reflects the two political branches' practical understanding, developed since the founding of the Republic, of their respective roles and responsibilities with respect to national defense ...."); Whether Uruguay Round Agreements Required Ratification as a Treaty, I8 Op. O.L.C. 232, 235 (1994) (referring to historical practice as reflecting "the considered constitutional judgments of the political branches"); HAROLD HongJu KOH, The NATIONAL SECURITY CONSTITUTION 70 (I990) (describing "quasi-constitutional custom" as including "executive practice of which Congress has approved or in which it has acquiesced [and] formal and informal congressional actions with which the president has consistently complied," and characterizing these customs as "carry[ing] greater normative weight than self-serving justifications that one branch may offer, without another branch's endorsement"); H. Jefferson Powell, Essay, The President's Authority over Foreign Affairs: An Executive Branch Perspective, 67 GEO. WASH. L. REv. 527 , 539 (I999) ("Agreement between the political branches on a course of conduct is important evidence that the conduct should be deemed constitutional."). 
I973 War Powers Resolution expressly agreed with the executive branch that the President had the constitutional authority to use military force in response to "a national emergency created by attack upon the United States, its territories or possessions, or its armed forces." 88 Typically, however, there is no such direct evidence of agreement. In its absence, interpreters may resort to more circumstantial evidence, including a failure by one branch to object to the practice of the other. In such cases, acquiescence is in effect treated as constructive agreement on the constitutional issue.

Arguments that view acquiescence this way are effectively arguments for deference to the constitutional views of nonjudicial actors. It is hardly novel for the courts to defer, in one way or another, to the constitutional judgments of the political branches. Although the academic debate between "judicial supremacists" and "departmentalists" persists, ${ }^{89}$ everyone recognizes that constitutional interpretation has never been the exclusive province of the judiciary. ${ }^{90}$ In the case of institutional acquiescence, a common assumption is that if one political branch has a constitutional disagreement with a practice that implicates its institutional powers or prerogatives, it will object. When the practice is repeated over time without any such objection, it is therefore appropriate to presume, on this view, that the political branches share a "practical understanding" as to the constitutionality of the practice. ${ }^{91}$ Privileging acquiescence can be understood as entailing deference to that presumed understanding.

In a similar but not identical vein, acquiescence is sometimes treated as evidence that the political branches have settled upon an institutional arrangement that they both deem desirable or at least practically workable and acceptable. Here again, acquiescence is taken to reflect interbranch agreement. But the agreement is at the level of op-

88 Pub. L. No. 93-I 48, § 2(c), 87 Stat. 555, 555 (I973) (codified at 50 U.S.C. § I54I(c) (2006)).

89 For articulations of the judicial supremacist view, see generally, for example, Larry Alexander \& Frederick Schauer, On Extrajudicial Constitutional Interpretation, I Io HARV. L. REV. I359 (1997); and Frederick Schauer, Judicial Supremacy and the Modest Constitution, 92 Calif. L. REV. I045 (2004). For leading departmentalist accounts, see generally TUSHNET, supra note 59; and Michael Stokes Paulsen, The Most Dangerous Branch: Executive Power to Say What the Law Is, 83 GEO. L.J. 2 I 7 (I994).

90 See Walter Dellinger \& H. Jefferson Powell, Marshall's Questions, 2 Green BAG 2D 367, 375-76 (I999) (discussing an I800 speech given by John Marshall while in the House of Representatives, which reveals that he thought "the courts are not the only institutions whose province and duty includes the exposition and interpretation of the law"); Morrison, supra note 38, at i69497 (collecting sources reflecting that the Supreme Court has never had a monopoly on constitutional interpretation); H. Jefferson Powell, The Province and Duty of the Political Departments, 65 U. CHI. L. REV. 365, 379 (I998) (book review) ("It is, to appropriate a phrase, the province and duty of the political departments, within their respective spheres, to say what the law of the Constitution is.").

91 Krass Memorandum, supra note 3, at 7. 
erational feasibility and acceptability, not legality in any express, formal sense. ${ }^{92}$ On this account, the fact that the political branches have worked out a particular arrangement through repeated practice over time suggests that it is normatively desirable. ${ }^{93}$ This view draws support from Burkean thinking, which, as noted in Part I, ${ }^{94}$ treats longstanding traditions as likely to reflect accumulated wisdom. It is also consistent with functional, as opposed to formal, approaches to the separation of powers. ${ }^{95}$ Whereas formalists emphasize the distinctness of the three branches and resist the intermingling of their powers, functionalists are concerned more with maintaining a workable system of checks and balances. From that perspective, the fact that one branch has long acquiesced in the practice of another may suggest that the practice is especially compatible with underlying constitutional values.

2. Acquiescence as Waiver. - Another approach treats acquiescence as a kind of waiver of the affected branch's institutional prerogatives, which may in turn generate institutional reliance interests. This idea is akin to the adverse possession doctrine in property law: if one branch of government has been engaging in a practice for a long time without any resistance, it (and potentially also third parties) may have formed reasonable expectation interests surrounding the practice. ${ }^{96}$ Moreover, in some cases, the practices of one political branch may have caused the other to assert new powers as a countervailing response. Acquiescence on one front may thus purchase new authority on another, and privileging acquiescence may be a way to honor the implicit bargain. ${ }^{97}$

92 See, e.g., Uruguay Round Agreements, I8 Op. O.L.C. at 233-34 (referring to the "practical construction placed on [the Constitution] by the executive and legislative branches acting together" and "the practical statesmanship of the political branches").

93 See, e.g., Sunstein, supra note 8, at 40I ("If Congress and President Bush have settled on certain accommodations, there is reason to believe that those accommodations make institutional sense.").

94 See supra p. 426.

95 There is reason to doubt the tenability of a purely functional or a purely formal approach to the separation of powers. See generally M. Elizabeth Magill, Beyond Powers and Branches in Separation of Powers Law, I50 U. PA. L. REv. 603 (200I). Still, those approaches represent two important themes in the scholarly and judicial reasoning in this area. For an argument that functionalism and formalism both err by contending that the Constitution embeds an overarching, general separation of powers principle (as opposed to a variety of clause-specific principles, operating at various levels of generality), see John F. Manning, Separation of Powers as Ordinary Interpretation, I24 HARV. L. REV. I939, I942-50 (201 I).

96 See, e.g., United States v. Midwest Oil Co., 236 U.S. 459, $472-73$ (1915) ("Both officers, lawmakers and citizens naturally adjust themselves to any long-continued action of the Executive Department - on the presumption that unauthorized acts would not have been allowed to be so often repeated as to crystallize into a regular practice.").

97 See McGinnis, supra note 8I, at 294 ("A power often does not remain in the branch in which it was initially placed, but may instead effectively be exercised elsewhere on account of the 
A possible example of such an implicit bargain relates to the treaty process. Although the Constitution specifies that the Senate is to provide "Advice and Consent" 98 to the conclusion of treaties, Presidents have not accorded the Senate a substantial advisory role in the making of treaties since early in U.S. history. ${ }^{99}$ Partly as a result of this exclusion, the Senate has long exercised the power to condition its consent to treaties on the adoption of "reservations" that decline to consent to particular treaty terms. ${ }^{100}$ Another potential example is "constitutional signing statements," in which Presidents express constitutional doubts about provisions in bills they are signing. ${ }^{101}$ The increased use of such statements in recent administrations may, in part, be a response to the rise of omnibus bills that Presidents feel they cannot veto in their entirety. ${ }^{102}$

These examples are not meant to suggest that interbranch bargains should always be accepted, even if they do serve the institutional interests of both the executive and legislative branches. In particular, it is far from clear that the political branches should have unlimited discretion to engage in transfers of authority that directly implicate individual liberty interests. ${ }^{103}$ Indeed, one arguable purpose of textual assignments of authority in the Constitution is to prevent or limit such transfers. ${ }^{104}$ The point here is simply that, if the focus is on preserving a particular balance of institutional authority, institutional bargains may be viewed as less problematic than unilateral aggrandizements of power.

3. Acquiescence and the Limits of Judicial Review. - If privileging acquiescence entails deferring to institutional arrangements worked out by the political branches (whether the arrangements are the product of actual interbranch agreement or the mere waiver by one branch of its constitutional prerogatives), a related argument is that the politi-

implicit bargains and accommodations that reflect the interests and capacities of the branches."); J. Gregory Sidak, To Declare War, 4I DUKE L.J. 27, 63 (I99I) ("Regardless of the initial assignment of powers under the Constitution, and as long as transaction costs are not too high, the Coase Theorem suggests that the three branches will be able to reassign those powers in any manner that achieves greater efficiency in the production of public goods." (footnote omitted)).

98 U.S. CONST. art. II, § 2, cl. 2.

99 See Curtis A. Bradley \& Jack L. Goldsmith, Treaties, Human Rights, and Conditional Consent, I49 U. PA. L. REV. 399, 405-06 (2000).

100 See id.

101 See Curtis A. Bradley \& Eric A. Posner, Presidential Signing Statements and Executive Power, 23 CONST. COMMENT. 307, 3I3-I4 (2006).

102 See id. at 313-14, 357-60.

103 Cf. Bond v. United States, I3 I S. Ct. 2355, 2365 (201 I) ("The structural principles secured by the separation of powers protect the individual as well.").

104 See Sidak, supra note 97, at 68 ("By requiring formality, the Constitution raises transaction costs and thus intentionally discourages certain bargains that otherwise could be struck between the branches of the federal government in the production of public goods."). 
cal branches may sometimes be better situated than the courts to enforce the constitutional terms of their relationship. ${ }^{105}$ For example, in treating the legality of President Carter's unilateral termination of a treaty with Taiwan as a political question, a plurality of the Supreme Court in Goldwater v. Carter emphasized that the case involved "a dispute between coequal branches of our Government, each of which has resources available to protect and assert its interests."106 While disagreeing with the plurality's application of the political question doctrine, Justice Powell concurred on the ground that the case was "not ripe for judicial review" because Congress had not attempted to use its resources to oppose the President's treaty termination, and thus there was no "constitutional impasse" between the branches. ${ }^{107}$

Justice Jackson made a related point in his Youngstown concurrence. As described above, ${ }^{108}$ he suggested that in cases arising in the "zone of twilight," "congressional inertia, indifference or quiescence may sometimes, at least as a practical matter, enable, if not invite, measures on independent presidential responsibility."109 Justice Jackson elaborated on this point by quoting Napoleon to the effect that "[t]he tools belong to the man who can use them"; Justice Jackson thus "ha[d] no illusion that any decision by this Court can keep power in the hands of Congress if it is not wise and timely in meeting its problems." 110 Ultimately, he emphasized, "only Congress itself can prevent power from slipping through its fingers."111 Justice Jackson's point

105 In effect, this idea amounts to saying that there are "political safeguards" of separation of powers akin to the purported political safeguards of federalism. See JesSE H. ChOPER, JudICial Review and the National Political Process 275 (ig80) (arguing that judicial review to police the boundaries of executive and legislative power is unnecessary because "[e]ach branch ... has tremendous incentives jealously to guard its constitutional boundaries and assigned prerogatives against invasion by the other," and "[i]f either branch perceives a constitutional violation of this kind, ... [it] possesses an impressive arsenal of weapons to demand observance of constitutional dictates by the other"). On the political safeguards of federalism, see generally Larry D. Kramer, Putting the Politics Back into the Political Safeguards of Federalism, roo COLum. L. REV. 2 I5 (2000); and Herbert Wechsler, The Political Safeguards of Federalism: The Role of the States in the Composition and Selection of the National Government, 54 COLUM. L. REV. 543 (I954).

106444 U.S. 996, I004 (1979) (Rehnquist, J., concurring in the judgment); see also Made in the USA Found. v. United States, 242 F.3d I300, I3 I I n.27 (I Ith Cir. 200I) ("[H]istorical practice may illuminate any prudential considerations governing the advisability or inadvisability of judicial intervention in a given controversy.").

107 Goldwater, 444 U.S. at 997-98 (Powell, J., concurring in the judgment); see also Levinson, supra note $8 \mathrm{I}$, at $723^{-24}$ ("It is an article of faith among contemporary courts and constitutional theorists that the legislative and executive branches will police and prevent one another's attempts at aggrandizement, making judicial supervision of separation of powers necessary only to maintain a level playing field between the competitive branches.").

108 See supra p. 419.

109 Youngstown Sheet \& Tube Co. v. Sawyer, 343 U.S. 579, 637 (1952) (Jackson, J., concurring).

110 Id. at 654

111 Id. 
was not that Congress necessarily will preserve its authority, but that ultimately only Congress can ensure that its power is preserved. The implications of this perspective for judicial review are more descriptive than normative: it is not so much that courts should not seek to preserve congressional power; it is that they cannot do so if Congress is unwilling to defend itself.

Part of the idea here may be that a too-activist judiciary risks having its judgments in this area ignored by the political branches. But the account need not be so cynical. Even assuming that the political branches will completely adhere to judicial decisions about the relationship between legislative and executive power, not all aspects of that relationship are reducible to justiciable cases and controversies. In addition, courts may not always have a clear on-the-ground sense of whether a given practice by one political branch truly intrudes upon the prerogatives or powers of the other, and the judicial tools for remedying such intrusions may be rather blunt and imprecise. For all these reasons, a judicial willingness to privilege institutional acquiescence is predictable, whether or not it is normatively ideal.

$* * *$

There are, then, a range of specific meanings attached to the concept of institutional acquiescence, and a corresponding variety of reasons for privileging it. These reasons depend in important respects on the assumption that each political branch is adequately motivated to raise constitutional objections - and will raise them, sooner or later - when the other branch intrudes on its prerogatives in a problematic way. If the political branches do not consistently guard their institutional prerogatives, it is not clear that the nonobjection of one branch to the practices of the other should be taken to reflect any agreement about the constitutionality of those practices. Nor is it clear that acquiescence should be treated as a valid waiver of institutional prerogatives, since there would be no assurance that the acquiescence reflects a mutually acceptable institutional bargain or achieves a desirable balance of power.

\section{B. The Madisonian Paradigm and Its Problems}

The assumption that the political branches consistently check each other in a way that protects their respective powers and prerogatives derives from a conception of the separation of powers articulated by James Madison in The Federalist No. $5{ }^{112}$ Under this conception,

112 See Levinson, supra note 6, at 950 ("Courts and theorists continue to embrace Madison's understanding of competition among empire-building branches as the primary dynamic of the 
the government's "constituent parts" would, "by their mutual relations, be the means of keeping each other in their proper places." 113 The personal ambitions of the officials in each branch would align with the prerogatives of their branch, so that the pursuit of the former would protect the latter, and each branch would check the other through a process of "[a]mbition . . . counteract[ing] ambition." 114 One of the virtues of this approach, Madison explained, is that it does not require that government officials act responsibly and police themselves. ${ }^{115}$ After all, "[i]f men were angels, no government would be necessary." 116 Instead, this model reflects a "policy of supplying, by opposite and rival interests, the defect of better motives."117

Unfortunately, this Madisonian theory is not an accurate description of modern separation of powers. As Posner and Vermeule have noted, "[w]hether or not this [Madisonian] picture was ever realistic, it is no longer so today."118 The Madisonian conception is most flawed with respect to its assumptions about Congress. To understand why this is so, it is necessary first to understand why Congress and the

constitutional separation of powers."). In referring to this conception of separation of powers as the "Madisonian conception," we take no position on whether The Federalist No. 5 I accurately or fully reflected Madison's thoughts on the matter. Cf. Samuel Kernell, "The True Principles of Republican Government”: Reassessing James Madison's Political Science, in JAMES MADISON: The Theory and Practice of Republican Government 92, 93 (Samuel Kernell ed., 2003) (arguing that The Federalist No. 5 I "does not represent Madison's sincere theoretical views on the Constitution"). It is sufficient for our purposes that the system described in The Federalist No. ${ }_{5} \mathrm{I}$ is the one envisioned by many scholars and judges. Nor are we claiming, of course, that Madison himself necessarily supported a historical gloss approach to constitutional interpretation like that discussed by Justice Frankfurter in Youngstown.

113 The Federalist No. 5 I (James Madison), supra note 47 , at 318.

114 Id. at 3 I 9 .

115 Id.

116 Id.

117 Id.; see also TUSHNET, supra note 59, at 98 (describing the Madisonian model as anticipating that, "[t]o preserve his or her own power, a member of Congress would be alert to attempts by the president to make the presidency more powerful; and similarly for the president").

118 Posner \& Vermeule, The Credible Executive, supra note 6, at 884; see also Neal Kumar Katyal, Internal Separation of Powers: Checking Today's Most Dangerous Branch from Within, I I YALE L.J. 23I4, 23I6 (2006) ("Publius's view of separation of powers presumes three branches with equivalent ambitions of maximizing their powers, yet legislative abdication is the reigning modus operandi."); Levinson \& Pildes, supra note 6, at 23 I 3 ("Few aspects of the founding generation's political theory are now more clearly anachronistic than their vision of legislative-executive separation of powers."). Even if modern separation of powers did work the way that Madison envisioned, it is not clear that it would produce socially optimal outcomes. See Adrian Vermeule, The Supreme Court, 2008 Term - Foreword: System Effects and the Constitution, I23 HARV. L. REV. 4, 27 (2009) ("[Madison's] argument lacks any mechanism to ensure that competition among institutions promoting their interests or ambitions will promote a state of affairs that is both patterned and desirable overall ...."). But that point is separate from the issue we are addressing here. 
President are not equally situated in their ability to take action. ${ }^{119}$ Here we draw on a mix of political science and legal scholarship exploring that point.

I. Structural Impediments to Congressional Action. - In order for Congress to enact legislation, either a majority of both houses must agree on the legislation and the President must decline to exercise his veto power, or a supermajority in both houses must agree on the legislation so that Congress can override the President's veto. ${ }^{120}$ Modern Presidents, by contrast, sit atop a vast executive branch and are able to take a wide variety of actions unilaterally. ${ }^{121}$ For example, Presidents issue executive orders and directives, initiate the use of military force, and conclude agreements with other countries without first seeking congressional approval. While Congress could in theory act to override such unilateral presidential action, such an override faces the difficult task of overcoming a likely presidential veto, and this fact will tend to discourage members of Congress even from trying. ${ }^{122}$ Moreover, as a result of its committee structure and internal practices such as the filibuster in the Senate, there are a variety of additional "vetogates" in Congress at which legislative proposals to constrain the President can be defeated. ${ }^{123}$

In addition to the veto limitation, Congress faces substantial collective action problems that are not present, at least to the same degree, in the executive branch. ${ }^{124}$ Because Congress is a plural body, all of its members benefit from the protection and enhancement of legislative authority even if some of them do not contribute to the effort. As a result, each individual member has relatively little incentive to expend resources trying to increase or defend congressional power, since he or she will not be able to capture most of the gains. ${ }^{125}$ Therefore, "[e]ven

\footnotetext{
119 See generally Terry M. Moe \& William G. Howell, The Presidential Power of Unilateral Action, I5 J.L. ECON. \& ORG. I32 (I999).

120 The President's veto power and certain other features of the Constitution were included in part as a reaction by the Founders to the dominance of state legislatures under the Articles of Confederation. See, e.g., The Federalist No. 48 (James Madison), supra note 47 , at 306 ("The legislative department is everywhere extending the sphere of its activity and drawing all power into its impetuous vortex."). For an account of how the President's veto power can have significant effects on legislation even when it is not exercised, see CHARLES M. CAMERON, VETO BARGAINING (2000).

121 See Moe \& Howell, supra note I19, at I38. Unilateral presidential action is a recurring phenomenon. For discussion of various unilateral actions by President Obama, see Charlie Savage, Shift on Executive Power Lets Obama Bypass Rivals, N.Y. TIMES, Apr. 23, 2012, at AI.

122 See, e.g., Derek Jinks \& Neal Kumar Katyal, Disregarding Foreign Relations Law, i 6 YALE L.J. I230, I255 (2007) ("[V]eto power functions ex ante as a disincentive even to begin the legislative reform process ....").

123 See Moe \& Howell, supra note I I9, at I46.

124 See Posner \& Vermeule, The Credible Executive, supra note 6, at 886.

125 See Eric A. Posner \& Adrian Vermeule, The Executive Unbound 23-24, $26-27$ (2010); Moe \& Howell, supra note I I9, at I44.
} 
when presidents are clearly taking action to push out the boundaries of their power, Congress will not tend to vote or respond on that basis, and will not, as a result, be able to defend or promote its institutional power very effectively." 126

One might object at this point that the collective action and related obstacles to congressional action are not defects in the system of separated powers, but intended features. Madison and other Founders were particularly mindful that "the tendency of republican governments is to an aggrandizement of the legislative at the expense of the other departments," 127 and for that reason they had a "profound conviction ... that the powers conferred on Congress were the powers to be most carefully circumscribed." 128 Arguably, therefore, the various structural barriers built into the legislative process are best understood as intentional restraints on the legislative power. If so, it may simply be that, in focusing on the danger of legislative aggrandizement, the Founders created a system that is not ideally suited to checking the power of the modern executive branch. Still, it would be a mistake to assume that the Founders gave no thought to restraining executive power. Even with the structural barriers to legislative action that are built into the Constitution itself, Madison and others envisaged a constitutional system in which the legislative and executive branches would be positioned and motivated to check each other effectively to exercise what Hamilton in a related vein called "a constitutional and effectual power of self-defense." 129

2. Political Asymmetries Between Congress and the Presidency. There is, moreover, an even greater problem with the Madisonian conception: wholly apart from their ability consistently to protect the interests of the legislative branch, members of Congress are not systematically motivated to do so. As Madison noted, in order for his conception of separation of powers to work, "[t]he interest of the man must be connected with the constitutional rights of the place"130 that is, government officials must be motivated to act in a way that

126 Moe \& Howell, supra note I I9, at I44; see also John Ferejohn \& Rick Hills, Blank Checks, Insufficient Balances 35 (Apr. 26, 20I2) (unpublished manuscript), available at http://www.utexas .edu/law/colloquium/papers-public/20 I I-20I2/04-26-I2_Ferejohn_BlankChecks.pdf (arguing that "the elaborate checks on congressional power have turned out to be extremely effective in preventing congressional reactions to presidential or judicial unilateralism," and that "things are arranged this way ... due to the framer's [sic] failure to anticipate how the various constitutional institutions would actually work").

127 The Federalist No. 49 (James Madison), supra note 47, at 3I2; see also THE FEDERALIST NO. 73 (Alexander Hamilton), supra note 47, at 44I (noting "[t]he propensity of the legislative department to intrude upon the rights, and to absorb the powers, of the other departments").

128 INS v. Chadha, 462 U.S. 919, 947 (I983).

129 The FEderalist No. 73 (Alexander Hamilton), supra note 47, at 44I (emphasis added).

130 The FEDeralist No. 5 I (James Madison), supra note 47, at 3 I 9. 
protects their branch's constitutional authority. Political science scholarship has made clear, however, that a primary motivation for many members of Congress is reelection. ${ }^{131}$ This is not to say that reelection is their only goal. The literature contains a range of views on this point, and some studies suggest that members of Congress act at least in part out of a desire to promote what they take to be good public policy. Yet even those studies do not claim that the pursuit of good policy is a consistently central motivation for congressional action. At most, they suggest that the promotion of good policy exists alongside the quest for reelection and other more personally self-serving factors. ${ }^{132}$ Reelection is always part of the picture, and on many accounts it is the "dominant goal."133 In its pursuit, legislators often focus on the views and interests of their local constituents, who are concerned more with specific policy outcomes than congressional power. ${ }^{134}$ Presidents, in contrast, enjoy a greater share of the power of their institution than members of Congress, and thus have more incentive to expend resources protecting and enhancing this power. ${ }^{135}$ In addition, modern Presidents, in order to secure reelection and a long-term legacy, seek to cultivate a reputation as an effective leader. Having power generally makes it easier to pursue that goal. ${ }^{136}$ Moreover, the public has come to expect Presidents to be at the forefront of addressing a wide range of domestic and international problems. Those voter ex-

131 See, e.g., R. Douglas Arnold, The Logic of Congressional ACtion 5 (ig9o) ("Although [members of Congress] are not single-minded seekers of reelection, reelection is their dominant goal."); MORRIS P. FiorinA, CONGREsS: Keystone OF THE WASHINGTON ESTABLISHMENT 39 (1977) ("[T]he primary goal of the typical congressman is reelection."); DAVID R. Mayhew, Congress: The Electoral Connection i3 (i974) ("United States congressmen are interested in getting reelected — indeed, in their role here as abstractions, interested in nothing else." (footnote omitted)); Victoria Nourse, Misunderstanding Congress: Statutory Interpretation, the Supermajoritarian Difficulty, and the Separation of Powers, 99 GEO. L.J. III9, I 25 (20II) ("There is nary a political scientist who does not believe that the electoral connection - whether viewed as a rosy aim to further the public good or a craven attempt to extract interest-group rents - is Congress's most distinctive feature.").

132 See, e.g., Richard F. FenNo, JR., CONGRESSMEN In COMmitTeEs I (I973) (describing the goals espoused by representatives as "re-election, influence within the House, and good public policy," as well as private gain and career success after leaving the House (emphasis omitted)); DAVID W. ROHDE, PARTIES AND LEAdERS IN THE POSTREFORM HOUSE 40 (I g9I) (same).

133 ARNOLD, supra note I3I, at 5.

134 See Moe \& Howell, supra note II9, at I44; see also Neal Devins, Party Polarization and Congressional Committee Consideration of Constitutional Questions, I05 NW. U. L. REV. 737, 762 (20I I) ("Although each of the 535 members of Congress has a stake in Congress's institutional authority to independently interpret the Constitution, parochial interests overwhelm this collective good.").

135 See Levinson, supra note 6, at 956; see also Neal Devins, Presidential Unilateralism and Political Polarization: Why Today's Congress Lacks the Will and the Way to Stop Presidential Initiatives, 45 WillametTe L. REV. 395, 399-400 (2009) ("[T]he President's personal interests and the presidency's institutional interests are often one and the same.").

136 See Moe \& Howell, supra note I I9, at I36. 
pectations provide an added incentive for Presidents to maintain and enhance the authority they think is necessary to succeed. ${ }^{137}$ The result is a "fundamental imbalance[:] Presidents have both the will and the capacity to promote the power of their own institution, but individual legislators have neither and cannot be expected to promote the power of Congress as a whole in any coherent, forceful way."138

The modern party system further reduces the incentives of individual members of Congress to act systematically in constraining executive power or resisting executive aggrandizement. Put simply, individual members of Congress tend overwhelmingly to act in accord with the preferences of their party. ${ }^{139}$ There are exceptions, of course; party affiliation is not a perfect predictor of voting behavior. Still, it is much more likely to predict a legislator's stance concerning any given presidential action than is institutional identity. ${ }^{140}$ As a result, the Madisonian model of interbranch rivalry is especially inaccurate during times of unified government. As Professor Douglas Kriner has noted, "the President's co-partisans stand to gain little from attacking the policies of their partisan ally in the White House and instead risk electoral losses from a tarnished party label." 141 Even in times of divided government, however, party interests in Congress track institutional interests only imperfectly. ${ }^{142}$ The fact that Congress lacks an institutional counterpart to the Office of Legal Counsel (which, among other things, monitors congressional inroads on executive authority) is an illustration of the executive branch's greater institutional focus. ${ }^{143}$

137 See Levinson, supra note 6, at 956-57.

138 Moe \& Howell, supra note I I9, at I45; see also Devins, supra note I35, at 399 ("Thanks both to the singularity of the office and the power to execute, Presidents are well positioned to advance their policy agenda and, in so doing, expand the power of the presidency.").

139 See generally Gregory L. Hager \& Jeffery C. Talbert, Look for the Party Label: Party Influences on Voting in the U.S. House, 25 LEGIS. STUD. Q. 75 (2000) (arguing that party membership influences congressional voting patterns even after controlling for ideological preferences); Samuel C. Patterson \& Gregory A. Caldeira, Party Voting in the United States Congress, I8 BRIT. J. POL. SCI. I I ( I 988 ) (noting that while aggregate levels of party voting in Congress vary according to time and congressional chamber, partisan cleavages play a significant role in legislative life).

140 See Levinson \& Pildes, supra note 6, at 2324-25.

141 Douglas Kriner, Can Enhanced Oversight Repair "The Broken Branch"?, 89 B.U. L. REV. 765,784 (2009).

142 See Levinson, supra note 6, at 959 (noting that the President and Congress will battle over power "only when they have been pressed into the service of someone's independent political agenda, not because of anyone's intrinsic interest in the power of the institutions themselves").

143 The House and Senate each have counsel's offices that engage in constitutional analysis, but they do not function like OLC. See, e.g., James E. Fleming, The Constitution Outside the Courts, 86 CORNEll L. REv. 2 I5, 247 n.I58 (2000) (reviewing Tushnet, supra note 59) ("The Senate and House also have their own offices of legal counsel - the Office of Senate Legal Counsel and the General Counsel to the House - but those bodies (more than the executive branch's Office of Legal Counsel) mainly engage in constitutional review in a defensive posture, after legislation has been passed and is being challenged in litigation.”). For a discussion of those offices, see Louis Fisher, Constitutional Analysis by Congressional Staff Agencies, in CONGRESS AND THE CON- 
This institutional focus does not mean that Presidents always can or will act to expand their authority. Even though the executive branch does not face the same collective action problems faced by Congress, the rise of the modern administrative bureaucracy limits the ability of the executive branch to take action. ${ }^{144}$ Like Congress, the executive branch is to some extent a "they" rather than an "it."145 Nevertheless, there is still no equivalent in Congress to the presidential leadership of the executive branch, and Presidents have tools for managing the bureaucracy. ${ }^{146}$ Of course, even when Presidents are able to act, they may voluntarily constrain themselves in some instances in order to enhance their public credibility. ${ }^{147}$ They may also decide to seek congressional support for some initiatives in order to share the political risk with Congress. ${ }^{148}$ In other instances, they may conclude that their partisan preferences are inconsistent with a particular claim of executive authority. These calculated decisions about whether to refrain from asserting executive power are different, however, from the Madisonian conception, under which attempts at executive aggrandizement are systematically checked by Congress.

3. Modern Congressional-Executive Relations. - The power of the modern presidency has been enhanced by the gradual accumulation over time of an extensive array of legislative delegations of power. The complexities of the modern economy and administrative state,

STITUTION 64, 75-8I (Neal Devins \& Keith E. Whittington eds., 2005). For a discussion of the differences between executive branch and congressional participation in litigation, see Amanda Frost, Congress in Court, 59 UCLA L. REV. $9 \mathrm{I} 4$ (20I2).

It is possible that, owing to senators' longer terms in office, the Senate has a somewhat greater institutional focus than the House. These longer terms, however, do not remove the collective action problems, the party politics, or the different expectations that the public has about the presidency.

144 See, e.g., Posner \& Vermeule, supra note 125 , at 27 ("Much of what presidents do is arbitrate internal conflicts among executive departments and try to aggregate competing views into coherent policy over time."); Elena Kagan, Presidential Administration, I I4 HARV. L. REV. 2245, 2263 (200I) ("[B]ureaucracy also has inherent vices (even pathologies), foremost among which are inertia and torpor.").

145 Posner \& Vermeule, supra note I25, at 27 ; Neomi Rao, Public Choice and International Law Compliance: The Executive Branch Is a "They," Not an "It," 96 MINN. L. REV. I94, I97 (20II).

146 See generally Kagan, supra note I44, at 228I-3 I9 (describing tools used by President Clinton to exercise control over the executive bureaucracy).

147 See, e.g., Posner \& Vermeule, The Credible Executive, supra note 6, at 867-68 ("By tying policies to institutional mechanisms that impose heavier costs on ill-motivated actors than on well-motivated ones, the well-motivated executive can credibly signal his good intentions and thus persuade voters that his policies are those that voters would want if fully informed."). For an analysis of one kind of voluntarily imposed constraint on executive power, see generally Jon D. Michaels, The (Willingly) Fettered Executive: Presidential Spinoffs in National Security Domains and Beyond, 97 VA. L. REV. 80I (20II) (discussing two cases where the Executive imposed constraints upon itself with respect to intelligence technologies and foreign investment).

148 See Nzelibe \& Stephenson, supra note 6, at 637. 
along with the heightened role of the United States in foreign affairs, have necessitated broad delegations of authority to the executive branch. ${ }^{149}$ In an effort to retain some control over these delegations, Congress for a long time included legislative veto provisions that would allow one or both Houses to override executive action under the statutes, but as noted earlier, the Supreme Court held such vetoes to be unconstitutional in INS v. Chadha. ${ }^{150}$ While statutory delegations to the executive tend to be more robust and unqualified during times of unified government, ${ }^{151}$ they have become a general hallmark of congressional-executive relations regardless of partisan alignments. ${ }^{152}$ Congress of course may have good reasons for such delegations, but the key point is that legislative power is being transferred to the executive branch rather than jealously guarded as envisioned by the Madisonian conception. ${ }^{153}$

To be sure, not all modern developments in congressional-executive relations have favored the Executive. Consider, for example, the rise of omnibus legislation and appropriations riders. These phenomena effectively reduce the power of the presidential veto, since the President does not have line-item veto authority and will often feel compelled to accept the overall legislative package proposed by Congress. ${ }^{154}$ As noted above, ${ }^{155}$ the presidential practice of sometimes issuing signing statements to express constitutional objections to (or constitutional doubt-avoiding constructions of) certain provisions in omnibus bills may offset at least some of the advantages to Congress of legislating in this fashion. Still, as a whole, the advent of omnibus legislation probably enhances congressional power. In any event, Congress's control over appropriations can give it significant leverage over the President in other ways, especially with respect to presidential initiatives that require new funding. ${ }^{156}$

149 See Moe \& Howell, supra note i i 9, at I4I.

150462 U.S. 9I9, 959 (I983). Despite Chadha, Congress still frequently includes legislative veto provisions in statutes, even though these provisions are presumably not judicially enforceable. When signing bills that contain these provisions, Presidents often issue signing statements challenging the constitutionality of the veto provisions. See LouIS FISHER, ConG. Research SeRV., RS22 I32, Legislative Vetoes After ChaDHA 5 (2005), available at http://www.loufisher.org/docs/lv/4 I i6.pdf.

151 See David Epstein \& Sharyn O'Halloran, Delegating Powers i i (i 999); Posner \& Vermeule, The Credible Executive, supra note 6, at 887 .

152 See Kriner, supra note I4I, at 769-7I.

153 See Levinson, supra note 6, at 953-54; Moe \& Howell, supra note I I9, at I4I-43.

154 See Bradley \& Posner, supra note IOI, at 34I. In some U.S. states, by contrast, legislatures face a single subject rule when enacting bills. See, e.g., Michael D. Gilbert, Single Subject Rules and the Legislative Process, 67 U. PITT. L. REV. 803, 8I 2 (2006).

155 See supra p. 436.

156 See Josh Chafetz, Congress's Constitution, i6o U. PA. L. REV. 715, 734-35 (2012); Moe \& Howell, supra note i i 9 , at 148 . 
In addition, Congress has a variety of "soft law" tools for monitoring and pushing back against the executive branch that are not subject to the collective action problems that beset the formal legislative process. These include oversight hearings, nonbinding resolutions, the threat of contempt proceedings, and public disclosure of information. ${ }^{157}$ Although the partisan composition of Congress and the White House is likely to affect the extent to which these tools are used at any given point, ${ }^{158}$ over time there has been sufficient bipartisan interest in these tools to maintain them as options. The oversight power may be an especially apt example here. Congress might not exercise this power in any consistently Madisonian fashion (preferring instead to use it for partisan purposes against administrations of the other party, or to advance policy goals of importance to the constituents of a committee chairman or other influential member), but members of Congress have come to understand oversight as a sufficiently valuable form of authority that the basic contours of the power have been asserted and preserved fairly consistently. ${ }^{159}$ Moreover, at any given time Congress is likely to contain at least a few members inclined to exercise the oversight power and other soft law tools in the pursuit of institutional or broader public interests, rather than purely partisan ones. ${ }^{160}$ Only congressional majorities can check the executive branch through formal legislation, but instruments of soft law do not require bicameral majorities. Those instruments thus hold out broader possibilities for resistance to executive aggrandizement. Nevertheless, there is no particular reason to think that these elements of congressional authority produce consistent, robust interbranch rivalry of the sort envisioned in The Federalist No. $5 \mathrm{I}$ - at least not given the realities of modern government.

This last qualification highlights an important point: the mismatch between the Madisonian model and actual executive-legislative practice is historically contingent. Although veto-gates like bicameralism and presentment are entrenched in the constitutional text, the existence and especially the extent of many other obstacles to effective congres-

157 See Chafetz, supra note I56, at 742, 753; Jacob E. Gersen \& Eric A. Posner, Soft Law: Lessons from Congressional Practice, 6I STAN. L. REV. 573, 594, 604 (2008).

158 See, e.g., Douglas Kriner \& Liam Schwartz, Divided Government and Congressional Investigations, 33 LEGIS. STUD. Q. 295, 297 (2008) (finding that congressional investigative activity is higher under divided government than under unified government).

159 For the Congressional Research Service's extensive Oversight Manual, which for over thirty years has staked out Congress's positions in this area, see FREDERICK M. KAISER ET AL., CONG. RESEARCH SERV., RL30240, CONGRESSiOnAl Oversight MANUAL (20II), available at http://www.fas.org/sgp/crs/misc/RL30240.pdf.

160 See Chafetz, supra note 156 , at $775-76$ ("[I]t is clear that there are always at least some legislators who act from a genuine desire to promote the public good" and thus have "an incentive to make vigorous, but judicious, use of [soft law] congressional powers ....”). 
sional checks on executive power - including members' tendency to think more in terms of party than branch, and the President's greater ability to appeal to the national electorate - are not fixed features of our constitutional order. They are defining elements of modern government, but at some earlier points in our history they may well have been less prominent. ${ }^{161}$ Thus, the inaptness of the Madisonian model should not be presumed to be constant over time, and we make no claim that it is.

In part because of the general weakness of congressional checks on executive power since World War II, many commentators agree that there has been a substantial growth in presidential power during this period, a phenomenon most famously described by Arthur Schlesinger as the rise of the "imperial presidency." 162 Unlike some, we do not intend this description to reflect any normative judgment. Whether the modern presidency is too powerful is a complicated question that depends on, among other things, a determination of the proper baseline and an assessment of constraints on the President other than the separation of powers. For our purposes, the key point is simply that the Madisonian conception of separation of powers is not an accurate description of modern congressional-executive relations. Although it is not uncommon for Congress and the President to disagree about specific policies (especially when at least one house of Congress is controlled by the opposing party), and while these policy disputes are sometimes framed in terms of institutional authority, as a body the modern Congress does not systematically seek to protect legislative authority from executive encroachment.

\section{REASSESSING HISTORICAL GLOSS}

In this Part, we consider the implications of the above discussion for the use of historical practice in constitutional argumentation. First,

161 Congress acted more systematically to rein in executive authority in the early I970s, through the enactment of important framework statutes such as the War Powers Resolution (directing the President to consult with Congress and obtain authorization before introducing the armed forces into hostilities), the Congressional Budget and Impoundment Control Act of I974 (asserting congressional control over the federal budgetary process), and the Case-Zablocki Act (requiring presidential reporting of executive agreements). See Richard H. Pildes, Law and the President, I25 HARV. L. REV. I38I, I383 (20I2) (reviewing POSNER \& VERMEULE, supra note I25) ("Only in the I970s did this general thrust in the direction of enhanced presidential power confront more complex terrain.”). But overall — and in contrast to earlier periods in U.S. history — the trend since the beginning of the Cold War has been away from congressional checks on presidential power. See, e.g., JACK Goldsmith, POWER AND CONSTRAINT 30-33 (20I2).

162 See, e.g., Pildes, supra note I6I, at I38I ("It is widely recognized that the expansion of presidential power from the start of the twentieth century onward has been among the central features of American political development.”). See generally ARTHUR M. SCHLESINGER, JR., THE IMPERIAL PRESIDENCY (I973). 
we discuss how the problems with the Madisonian model affect acquiescence-based arguments for relying on historical practice. Second, we discuss the circumstances under which it might make sense to credit historical practice even in the absence of a meaningful finding of institutional acquiescence.

\section{A. Implications for Acquiescence Arguments}

The Madisonian model's descriptive shortcomings carry several significant implications for relying on ideas of institutional acquiescence to resolve separation of powers controversies. Although we do not think these shortcomings are fatal for all possible claims of acquiescence, they do demand much greater care and precision in making and evaluating such claims.

I. Legislative Acquiescence. - Perhaps most significantly, the problems with the Madisonian model show that it is precarious to infer congressional acquiescence from what might appear, on a surface level, to be congressional silence - especially if that "silence" is simply the absence of legislation prohibiting the executive action in question. The various veto-gates through which formal legislation must pass, as well as collective action problems and the likelihood that individual members think more in terms of party than institution, provide a host of reasons why Congress might not legislate in a particular circumstance. Many of those reasons have nothing to do with the ideas of institutional agreement or waiver undergirding theories of acquiescence.

To concretize the point, consider an example that we will expand upon in Part IV. In the area of war powers, Congress generally does not impose meaningful constraints on unilateral presidential uses of military force, except in times of divided government. ${ }^{163}$ This fact supports the proposition that in the war powers area, many in Congress tend to act on the basis of considerations like party loyalty rather than institutional affiliation. ${ }^{164}$ Thus, Congress's failure to object to a particular presidential use of military force may reflect partisan political calculations by actors who are not particularly concerned about the constitutional prerogatives of the legislative branch as such. And that possibility, in turn, undercuts the Madisonian basis for treating such congressional inaction as acquiescence.

This does not mean, however, that ideas of congressional acquiescence should be abandoned altogether. Instead, it suggests that where acquiescence is the touchstone of the analysis, the standard for legislative acquiescence should be high. To see what this might mean, con-

163 See William G. Howell \& Jon C. Pevehouse, While Dangers Gather: ConGRESSIONAL CHECKS ON PRESIDENTIAL WAR POWERS 222-23 (2007).

164 See id. at 222. 
sider first that congressional agreement with a particular exercise of executive power can be expressed in a variety of ways. At one end of the spectrum are relatively straightforward cases where Congress, in legislation, specifically refers to and approves of a particular executive practice. A potential example, again from the war powers context, is the specific acknowledgment in the War Powers Resolution that the President has the authority to use military force in response to "a national emergency created by attack upon the United States, its territories or possessions, or its armed forces." 165 Similarly, there may be cases where a legislative enactment clearly implies congressional approval of an executive practice. Executive settlement of the claims of U.S. citizens against foreign governments may be a good example. ${ }^{166}$ In these cases, Congress may be taken not simply to have acceded to the practice but to have authorized it to at least some degree. The President's power is rightly understood to be at its apex in such circumstances. ${ }^{167}$

At the opposite end of the spectrum are cases where Congress has passed legislation explicitly or by clear implication prohibiting, disapproving, or restricting particular exercises of executive power. The President's power is commonly understood to be at its "lowest ebb" in such circumstances, ${ }^{168}$ and we agree with that general proposition. Indeed, given the institutional and other barriers to the passage of legislation restricting presidential power, we think that when Congress has managed to pass such legislation, its actions should be given very heavy interpretive weight. As an example, Congress's disallowance of warrantless wiretapping in the Foreign Intelligence Surveillance Act of I 978 should have made a practice-based argument for such wiretapping authority (such as the one made by the Bush Administration in $2006^{169}$ ) particularly difficult to sustain, at least if the argument were premised on institutional acquiescence. ${ }^{170}$

165 Pub. L. No. 93-I $48, \S 2$ (c), 87 Stat. 555, 555 (I973) (codified at 50 U.S.C. $§$ I54I(c) (2006)).

166 In I949, after a long history of settlement of claims against foreign nations by the executive branch, Congress enacted a claims settlement statute that set forth a procedure pursuant to which funds resulting from future settlements could be distributed. In Dames \& Moore v. Regan, 453 U.S. 654,680 (I98I), the Court concluded that, "[b]y creating a procedure to implement future settlement agreements, Congress placed its stamp of approval on such agreements."

167 See Youngstown Sheet \& Tube Co. v. Sawyer, 343 U.S. 579, 635-37 (I952) (Jackson, J., concurring).

168 Id. at $637-38$.

169 See supra note 26.

170 See, e.g., February 2, 2006 Letter from Scholars and Former Government Officials to Congressional Leadership in Response to Justice Department Whitepaper of January 19, 2006, 8I IND. L.J. I4I5, I4I9 (2006) ("[T] say that a President may undertake certain conduct in the absence of contrary congressional action does not mean that he may undertake that action where Congress has addressed the issue and disapproved of executive action."); $f f$. Neal Katyal \& Richard Caplan, The Surprisingly Stronger Case for the Legality of the NSA Surveillance Program: The FDR 
Of course, the difficult cases are those falling in what Justice Jackson called the "zone of twilight" between the poles of clear legislative authorization and prohibition. ${ }^{171}$ The greatest risk here is in too readily concluding that Congress has remained silent in such cases, and consequently inferring acquiescence from such purported silence. The obstacles inherent in the legislative process make it very difficult to enact formal prohibitions of any given executive actions, and so Congress may well rely on more informal "soft law" to influence the conduct of the executive branch. If the point of looking to past practice is to determine the presence or absence of institutional acquiescence, the analysis must consider whether members of Congress have employed such instruments to express nonacquiescence. ${ }^{172}$

The treatymaking power provides an example. Article II of the Constitution states that the President has the power to make treaties "by and with the Advice and Consent of the Senate... provided two thirds of the Senators present concur." 173 This language might suggest that Presidents may constitutionally enter into binding international agreements only by obtaining Senate supermajority approval. Yet Presidents have long concluded some international agreements by other means, including by "congressional-executive agreements" - that is, executive agreements concluded with the ex ante or ex post approval of a majority of Congress. As we discuss in greater detail in Part IV, arguments about the extent to which such agreements may be used instead of Article II treaties have relied heavily on claims about historical practice, and the interaction between the executive branch and Congress (or, more particularly, the Senate) in this area provides evidence of soft law constraints on the Executive. Specifically, the Senate, in providing its advice and consent to various arms-control treaties, has issued accompanying declarations that such agreements should be concluded only pursuant to the treaty power and not by congressional-executive agreement. ${ }^{174}$ As we elaborate in Part IV, there is evidence that such statements have affected the Executive's selection between Article II treaties and congressional-executive agreements in certain contexts. Analysis of whether and to what extent the Senate has acquiesced in the use of congressional-executive agreements should take account of such statements.

Precedent, 60 STAN. L. REV. I023, I027 (2008) ("[T]oday's surveillance program, in many key respects, looks strikingly similar to the one blessed by [President Roosevelt]. . . . [W]e believe that the facts reveal that both programs were illegal.").

171 Youngstown, 343 U.S. at 637 (Jackson, J., concurring).

172 See Gersen \& Posner, supra note 157 , at 603 (suggesting that nonbinding congressional resolutions and other forms of soft law are "better indicator[s] of legislative views than legislative inaction").

173 U.S. CONST. art. II, § 2, cl. 2.

174 See infra p. 474. 
Expanding the inquiry to include a wider array of congressional responses to executive action will substantially shrink the universe of cases where Congress can truly be said to have remained silent, which will in turn shrink the number of cases drawing inferences from such silence. That is all to the good. Congress is a plural body - a "they," not an "it." 175 Thus, assigning interpretive consequences to congressional silence or inaction is perilous at best. ${ }^{176}$ If acquiescence is supposed to reflect a constitutional understanding that is sufficiently widespread to be attributed to Congress as an institution, courts and other interpreters should strongly prefer affirmative evidence of that understanding, not just silence.

Of course, an expanded inquiry of the sort we are urging will also raise line-drawing questions. It is unclear how much evidence of disagreement with a given pattern of executive action should be enough to establish nonacquiescence. ${ }^{177}$ If Presidents have undertaken certain actions for decades without any formal legislative response or public expression of disapproval by either party's congressional leadership, isolated objections by a few members of either chamber probably should not be enough to defeat an argument of acquiescence. Otherwise, claims of acquiescence would effectively be subject to a heckler's veto. We do not purport to know precisely where the line should be drawn in each case. But in general we favor an analytical approach that tends to include rather than exclude evidence of direct congressional engagement with the executive action in question, so that the analysis focuses more on that evidence than on the meaning of supposed congressional silence.

The foregoing discussion has considered claims of congressional acquiescence without special regard for the identity of the interpreter evaluating those claims. Yet the same shortcomings with the Madisonian model that undercut claims of congressional acquiescence in general also carry specific implications for the role of the courts in this area. It is a form of judicial deference for a court to privilege historical practice. When articulated in terms of institutional acquiescence, the argument for deference depends on the assumptions of interbranch competition embedded within the Madisonian model. Recall, for example, the plurality's statement in Goldwater $v$. Carter that judicial

\footnotetext{
175 See generally Kenneth A. Shepsle, Congress Is a "They," Not an "It": Legislative Intent as Oxymoron, I2 INT'L REV. L. \& ECON. 239 (I992).

176 See generally William N. Eskridge, Jr., Interpreting Legislative Inaction, $87 \mathrm{MICH}$. L. REV. 67 (1988) (arguing that legislative inaction should rarely be given much, if any, weight in divining actual collective will or desire of the enacting legislature).

177 Note, moreover, that when members of Congress succeed in using soft law and related tools to constrain executive action, the result will be the absence of an exercise of executive power. Such absences need to be taken into account when defining the scope of the executive practice to which Congress can be said to have acquiesced.
} 
abstention was appropriate with respect to whether the President has the authority to terminate treaty commitments because the case involved "a dispute between coequal branches of our Government, each of which has resources available to protect and assert its interests." 178 Given that this Madisonian premise does not fit the modern reality of executive-legislative relations, such rationales for judicial deference are weakened. This is particularly so for claims of congressional acquiescence. If there are problems with inferring acquiescence from congressional silence in the face of certain executive actions, then an argument for judicial deference to those actions that relies on a presumption of acquiescence is undercut as well.

The implication here is that courts should be more circumspect about invoking congressional acquiescence as a basis for deferring to executive practice. By itself, this point does not defeat all arguments for judicial deference in matters relating to executive power. It does suggest, however, that such arguments should be closely scrutinized, to ensure that they are not based on the kinds of Madisonian assumptions about congressional capacity and motivation that we have shown to be problematic here.

2. Executive Acquiescence. - Claims of executive acquiescence to congressional action, in contrast, are somewhat less problematic. The executive branch faces fewer collective action and veto obstacles than does Congress, and thus it is easier for the President and those serving under him to take legally consequential steps to protect executive prerogatives. Moreover, there are legal offices within the executive branch that devote considerable energy to ensuring that new legislation does not intrude unduly on executive prerogatives. That objective is a key aspect of OLC's "bill comment" practice, for example, which involves reviewing pending legislation for constitutional issues. ${ }^{179}$ OLC performs that task on the understanding that "[e]xecutive branch lawyers ... have a constitutional obligation ... to assert and maintain the legitimate powers and privileges of the President against inadvertent or intentional congressional intrusion."180 In addition, if OLC thinks a bill intrudes unconstitutionally on executive power and if that concern is not resolved before the bill comes to the President for his signature, the same concern is liable to be expressed in a signing

178444 U.S. 996, I004 (I979) (Rehnquist, J., concurring in the judgment).

179 See Morrison, supra note 38, at I7I2 n.93 (describing the role of OLC bill comments in the interaction between an administration and Congress over pending legislation); Cornelia T.L. Pillard, The Unfulfilled Promise of the Constitution in Executive Hands, Io3 MICH. L. REV. 676, 7 I I-I 2 (2005) (describing the bill comment process).

180 The Constitutional Separation of Powers Between the President \& Cong., 20 Op. O.L.C. I 24, I 26 (I996). 
statement. ${ }^{181}$ And there are other means of expressing constitutional opposition to legislation even after it is enacted, including publicly refusing to enforce or comply with the statute. Presidential administrations regularly avail themselves of one or more of these means, on the understanding that failure to do so could be taken as acquiescence.

The very existence of OLC is an example of the institutional differences between the executive and legislative branches that powerfully affect how historical practice is produced and treated in those branches. A significant implication of these differences, we think, is that the standard for assessing executive acquiescence should not be the same as the standard for assessing legislative acquiescence. Others have argued to the contrary. In an exhaustive scholarly treatment of the history of legislative restrictions on the President's power to remove executive officials (another area to which we will return in greater detail in Part IV), Professors Steven Calabresi and Christopher Yoo first contend that the original understanding of the constitutional text and structure contemplated an exclusive, illimitable presidential removal power. ${ }^{182}$ They then measure historical practice against that baseline. ${ }^{183}$ In doing so, they invoke the strict language in Justice Frankfurter's Youngstown concurrence regarding congressional acquiescence, and apply the same standard to questions of executive acquiescence. ${ }^{184}$ Calabresi and Yoo treat it as self-evident that "[i]f [Frankfurter's formulation] is the standard for evaluating congressional acquiescence to executive assertions of power, it logically follows that a converse standard should apply in evaluating presidential acquiescence to congressional assertions of power."185 We disagree. There may be an intuitive attraction to such symmetry, but differences in institutional structure and composition counsel in favor of different standards.

Consider two distinct contexts in which those differences might play out. First, precisely because the executive branch contains offices like OLC devoted to the protection of executive prerogatives, express or clearly implied concessions by those offices to limits on executive

181 See generally Bradley \& Posner, supra note IOI.

182 See CALABRESI \& YoO, supra note 44, at I4-I6, 33-38.

183 See $i d$. at 27 ("Only if there has been presidential acquiescence in a departure from the unitary executive could such a practice justifiably be regarded as an established part of the structure of our government."). Other scholars who have examined the Founding materials have contested Calabresi and Yoo's version of the original understanding. See, e.g., Martin S. Flaherty, Relearning Founding Lessons: The Removal Power and Joint Accountability, 47 CASE W. RES. L. REV. I563 (I997); Victoria F. Nourse \& John P. Figura, Toward a Representational Theory of the Executive, 9I B.U. L. REV. 273 (20I I) (book review). We take no position here on who has the better of the argument.

184 CALABRESI \& YOO, supra note 44, at 25-26.

185 Id. at 25 . 
power should carry especially great weight. A potential example is OLC's suggestion in its Libya war powers opinion, mentioned in the Introduction and discussed in greater detail in Part IV, that the Constitution might require congressional authorization for "prolonged and substantial military engagements, typically involving exposure of U.S. military personnel to significant risk over a substantial period." 186 If reinforced across a number of presidential administrations, a statement of this sort should be regarded as a kind of self-imposed acquiescence to limits on presidential power.

Second, because OLC and other executive offices understand that failure to object to legislative limits on executive authority may be treated as accepting their constitutionality, it is sensible for a court or other interpreter to treat such failures that way. Executive silence, in other words, should generally carry greater weight than congressional silence. But we would add a caveat here: executive silence in the face of a legislative restriction on executive power is most significant where the executive branch has actually complied with the legislative limit in question. There may be some cases where the practice of government simply does not bring the legislative limit into play for many years, so that there is little or no relevant practice one way or the other. As the Supreme Court has explained, "[w]hen instances which actually involve the question are rare, or have not in fact occurred, the weight of the mere presence of acts on the statute book for a considerable time, as showing general acquiescence in the legislative assertion of a questioned power, is minimized." 187 When, in contrast, the executive branch has over time complied with the legislative restrictions in question, the basis for finding executive acquiescence is much stronger. ${ }^{188}$

We emphasize that inquiries into executive acquiescence should focus on repeated executive compliance with legislative restrictions over time. That is, although the standard for executive acquiescence should be lower than for legislative acquiescence, individual instances of executive nonobjection to legislative restrictions should not be enough. Otherwise, the outlier decisions of a single administration could change the constitutional order. That would go well beyond anything tenably described as a historical practice-based approach. The courts, for their part, have been reluctant to take that route, precisely out of a concern that the current occupant of the White House should not so easily be able to "bind his successors." 189

186 Krass Memorandum, supra note 3, at 8.

187 Myers v. United States, 272 U.S. 52, I 7 I (1926).

188 See Glennon, supra note 5, at I 34 (arguing that "the custom in question must consist of acts; mere assertions of authority to act are insufficient").

189 Free Enter. Fund v. Pub. Co. Accounting Oversight Bd., I30 S. Ct. 3I38, 3 I55 (2010); see also Nixon v. Adm'r of Gen. Servs., 433 U.S. 425, 556-57 (I977) (Rehnquist, J., dissenting) ("[T]he 
In areas not subject to judicial review, those attempting to describe what the law is at any given point should also be wary about treating individual concessions by particular administrations as constitutionally decisive. Consider again OLC's acceptance in its recent Libya opinion of potential limits on the President's unilateral power to use military force. Because the executive branch is generally better situated than Congress to ensure consistent protection of its prerogatives, we think this concession is noteworthy. But the historical gloss approach is most concerned with practices that accumulate and solidify over time - hence our suggestion above that the weight of the Libya opinion's concessions should depend in part on whether they are agreed to and acted upon by later administrations. Moreover, the greatest weight should probably be reserved for bipartisan institutional acceptance over time. In those circumstances, the practice is most justifiably attributed to the executive branch as such, not simply to certain temporary occupants of it.

\section{B. Historical Practice Without Acquiescence}

Although claims about institutional acquiescence appear frequently in arguments from historical practice, not all reasons for invoking practice depend on acquiescence. Thus, even if the descriptive shortcomings in the Madisonian model were enough to warrant abandoning ideas of acquiescence altogether, there could still be a role for historical practice. Here we consider some reasons for privileging practice without acquiescence.

I. Burkean Values and Principled Decisionmaking. - Burkean approaches to constitutional interpretation could look to historical practice even in the absence of any evidence of acquiescence. A Burkean's "bias in favor of . . the status quo" 190 need not depend on ideas of acquiescence; it can instead be animated by a basic belief in the value of established ways of doing things and a concern about the risks of change. ${ }^{191}$

Relatedly, in some areas, historical practice might simply provide the most principled means of deciding disputes. On war powers, for example, once it is conceded that the President has some (but not un-

principle of separation of powers ... may not be signed away by the temporary incumbent of the office which it was designed to protect.”); Al-Bihani v. Obama, 6 I9 F.3d I, 47 n.26 (D.C. Cir. 2010) (Kavanaugh, J., concurring in denial of rehearing en banc) ("In court, the Executive Branch does not always press the most expansive possible argument in support of its legal authority - whether for reasons of policy, politics, litigation strategy, international concern, or otherwise. Courts must be careful before enshrining such concessions into binding judicial precedent protected by stare decisis that a future Executive could not readily undo.”).

190 Merrill, supra note 54, at 5 I3 (emphasis omitted).

191 See id. at 515, 518-19 (discussing the virtues of constitutional interpretation that "preserve[s] continuity with the past"). 
limited) power to direct the use of military force without congressional authorization, it is not clear how one could reliably define the boundary of that power without looking to past practice. Whether or not relying on such practice will produce desirable outcomes (that is, whether or not one agrees with the Burkean's normative preference for the status quo), in some situations it may be an almost inevitable feature of the need to provide a reasoned explanation for reaching a particular conclusion.

2. The Legitimacy of Law and the Role of the Courts. - To the extent past practice predicts the future actions of the branches, it should arguably inform legal analysis because descriptions of what the law is should have some correspondence to operational reality. In this way, appeals to historical practice have a connection to broader claims about the legitimacy and meaning of law. Under at least some accounts, one factor that affects law's legitimacy - and perhaps even whether something is properly described as law - is whether it generally accords with the actual behavior of the participants in the legal system. ${ }^{192}$ Especially in areas where the prospect of judicial review is remote, descriptions of the law or a legal system that ignore longstanding institutional practice are likely to fail on descriptive grounds. Moreover, if in fact government actors look to past practice to inform their understanding of - and to shape their claims about - the law, legal philosophers working in the tradition of H.L.A. Hart would treat that second-order practice as itself a fundamental feature of the legal order. ${ }^{193}$ In the same way that entrenched judicial precedents form part of what the law is even if there is reason to believe they were wrongly decided, it can be argued that any account of the law of executive and legislative power must take account of how the branches have actually acted over time.

192 See, e.g., LON L. Fuller, The Morality OF LAW 8i (ig64) (discussing the importance of "congruence between official action and the law"); see also CALABRESI \& YoO, supra note 44, at 4 (" $[\mathrm{A}]$ foundational principle of law is that to some degree what the law is on the books is determined by what it actually is in practice."); Henry Paul Monaghan, Supremacy Clause Textualism, I Iо COLUM. L. REV. 73I, 790 (2010) ("Any acceptable theory of constitutional adjudication should ... have two qualities: (I) It must be normatively acceptable and (2) It must be able to account for most (though not necessarily every last bit) of the current constitutional order.").

193 See H.L.A. HART, The CONCEPT OF LAW 94-99 (2d ed. I994) (discussing secondary "rules of recognition"); see also, e.g., Jules L. Coleman, Negative and Positive Positivism, i I J. LEGAL STUD. I39, I48 (I982) (discussing legal positivism's preoccupation with official practice); Monaghan, supra note I92, at 79I ("That law is what officials accept and apply as law is not a new insight ....."); Stefan Sciaraffa, The Ineliminability of Hartian Social Rules, 3I O.J.L.S. 603, 604 (20II) (discussing "the Hartian insight that customary practice is an ineliminable and fundamental feature of legal systems"). Of course, debates among legal philosophers over the nature and basis of law are complex and ongoing, and we do not mean to enter those debates here. Instead, our point is merely to identify another reason why an interpreter might accord significance to historical practice in this context. 
This need to ensure that the law maps relatively well onto actual institutional practice, while perhaps most acute when judicial review is unavailable, can also support judicial deference to at least certain entrenched practices. The case for such deference is particularly strong if there is reason to believe that the practice in question is part of an interbranch bargain, the full scope of which may be invisible to a court. Where that is the case, judicial invalidation of the practice will undo only part of the bargain, potentially creating an imbalance in executive-legislative relations. ${ }^{194}$ The case for judicial deference in this context tends to highlight considerations of judicial capacity and prudence, and to recognize that there are some things courts cannot realistically undo. Recall Justice Jackson's statement in Youngstown that the Court cannot "keep power in the hands of Congress if it is not wise and timely in meeting its problems," and that "only Congress itself can prevent power from slipping through its fingers." 195 Whether or not Congress is realistically likely to take action to preserve its power, part of Justice Jackson's point here is that the Court cannot protect congressional power in the long run. That observation is generalizable to the preservation of executive as well as legislative power. As noted above, the Court is prepared to resist novel intrusions by one branch on the prerogatives of the other, especially when it views nonpractice materials as establishing quite clearly the unconstitutionality of the intrusion. ${ }^{196}$ But the Court has much less inclination and capacity to revise more longstanding, entrenched arrangements under which both branches have operated. ${ }^{197}$

3. Internal Reliance by the Executive Branch. - A separate point is that, especially on matters unlikely to come before the courts, the executive branch in particular is liable to privilege past executive prac-

$194 C f$. INS v. Chadha, 462 U.S. 9I9, 967-68 (I983) (White, J., dissenting) (arguing that the Court's decision to invalidate the "legislative veto" was insensitive to this problem).

195343 U.S. 579, 654 (I952) (Jackson, J., concurring).

196 See supra p. 454.

197 See, e.g., United States v. Curtiss-Wright Exp. Corp., 299 U.S. 304, 329 (I936) (explaining, in declining to invalidate a congressional delegation of foreign affairs authority to the President, that "[t]he uniform, long-continued and undisputed legislative practice" of making broad delegations to the President in foreign affairs "rests upon an admissible view of the Constitution which, even if the practice found far less support in principle than we think it does, we should not feel at liberty at this late day to disturb"). We note, however, a tension between judicial review and a flexible, practice-based approach to law. Allowing the law to develop through practice can make it easier for it to respond over time to changing conditions. Yet judicial intervention poses the risk of freezing the evolution of customary practice, both by creating binding precedent and by serving as a new focal point around which the political branches will conduct their relations. $C f$. Thompson v. Oklahoma, 487 U.S. 8I5, 854-55 (I988) (O'Connor, J., concurring in the judgment) (noting parallel issue in connection with the Supreme Court's application of the "evolving standards of decency" test in Eighth Amendment jurisprudence). That said, judicial review has its own potential advantages, including the ability to clarify the law, protect third parties, and respond to potential inefficiencies in the way that the practice is being generated. 
tices and legal interpretations even when they diverge from the views of Congress. This tendency is evident in the work of OLC. Although OLC sometimes stresses the acquiescence idea, on other occasions it places special weight on executive branch precedents and practices even in the face of repeated congressional disagreement. ${ }^{198}$ Whereas the former approach seeks to identify converging constitutional understandings between the political branches, the latter approach may be best understood as an exercise in institutional self-defense. As discussed above, such self-defense is an important aspect of OLC's bill comment practice. ${ }^{199}$ There are a number of areas where OLC has consistently resisted congressional attempts to legislate, on the ground that the legislation would intrude unconstitutionally upon executive prerogatives. In the foreign affairs area, for example, Congress has at various points over the last few decades contemplated legislation that would direct or otherwise limit how the executive branch conducts diplomacy. OLC has repeatedly resisted such legislation, and in so doing has invoked its own consistent stance on these issues. ${ }^{200}$ The fact that Congress has repeatedly contemplated such provisions and that the executive branch has consistently resisted them underscores the lack of acquiescence from either branch in this area. Still, OLC evidently regards its own precedents and other past executive practices as important resources for resisting what it deems to be impermissible legislative intrusions on executive power. ${ }^{201}$

Similarly, the executive branch sometimes relies on its own past interpretations of certain legislative limits on executive power to support a narrow reading of those limits, without expressly raising any constitutional objection. A recent example is the Obama Administration's conclusion that its ongoing involvement in the $20 \mathrm{II}$ military operation in Libya did not rise to the level of "hostilities" within the meaning of the War Powers Resolution, and thus was not subject to the Resolution's requirement that the operation cease within sixty days if not au-

198 See, e.g., Memorandum from David J. Barron, Acting Assistant Att'y Gen., Office of Legal Counsel, to Joan E. Donoghue, Acting Legal Adviser, Dep't of State, Constitutionality of Section 7054 of the Fiscal Year 2009 Foreign Appropriations Act 8 (June I, 2009) [hereinafter Barron Memorandum], available at http://www.justice.gov/olc/2009/section7054.pdf.

199 See supra pp. $45^{2-53}$.

200 See, e.g., Barron Memorandum, supra note $\mathrm{I} 98$, at 8 ("[T]his Office has 'repeatedly objected on constitutional grounds to Congressional attempts to mandate the time, manner and content of diplomatic negotiations,' including in the context of potential engagement with international fora." (quoting Memorandum from Walter Dellinger, Assistant Att'y Gen., Office of Legal Counsel, to Alan Kreczko, Legal Adviser, Nat'l Sec. Council, Re: WTO Dispute Settlement Review Commission Act 3 (Feb. 9, I995))); see also id. at 8-9 \& nn.9-I I (discussing similar executive branch precedents from the Carter, Reagan, George H.W. Bush, and Clinton Administrations).

201 See Morrison, supra note 64 , at I 500-OI (discussing and defending this practice). 
thorized by Congress. ${ }^{202}$ In testimony before the Senate Foreign Relations Committee, State Department Legal Adviser Harold Koh placed heavy reliance upon a I975 letter to Congress from the then-State Department Legal Adviser and Defense Department General Counsel, stating that the executive branch understood "hostilities" to refer to "a situation in which units of the U.S. armed forces are actively engaged in exchanges of fire with opposing units of hostile forces," but not to include "irregular or infrequent violence which may occur in a particular area." "203 Koh asserted that in the years since that letter was submitted, "the executive branch has repeatedly articulated and applied th[e] foundational understandings" expressed in it, and that President Obama was "operating within this longstanding tradition of executive branch interpretation when he relied on these understandings" to conclude that the Libya operation did not constitute "hostilities."204 Whatever the merit of that account of the Libya operation, the critical point for our purposes is that Koh's testimony did not even attempt to claim any interbranch agreement or congressional waiver concerning the meaning of "hostilities." It simply claimed fidelity to executive interpretations (as well as actions consistent with those interpretations), any congressional views to the contrary notwithstanding.

Viewed from within the executive branch, the tendency to rely on executive practice is both understandable and defensible. As noted in section I.B.I, some of the same rationales for the judicial doctrine of stare decisis - such as predictability, efficiency, and credibility - can also support giving weight to nonjudicial practices. ${ }^{205}$ These justifications are particularly strong for executive practices supported by OLC legal opinions, which are treated as presumptively binding within the executive branch. ${ }^{206}$ Moreover, it is understandable that executive actors would accord special weight to OLC precedents and past executive practices that protect what they deem to be core executive prerogatives. ${ }^{207}$

202 For an overview of the "hostilities" issue as applied to the Libya operation, see generally Trevor W. Morrison, "Hostilities," i J.L. (i PUB. L. MISC.) 233 (20 I I).

203 Letter from Monroe Leigh, Legal Adviser, Dep't of State, and Martin R. Hoffmann, Gen. Counsel, Dep't of Def., to Clement J. Zablocki, Chairman, Subcomm. on Int'l Sec. \& Scientific Affairs of the H. Comm. on Int'l Relations (June 3, 1975), reprinted in War Powers: A Test of Compliance Relative to the Danang Sealift, the Evacuation at Phnom Penh, the Evacuation of Saigon, and the Mayaguez Incident: Hearings Before the Subcomm. on Int'l Sec. \& Scientific Affairs of the H. Comm. on Int'l Relations, 94th Cong. 39 (I975).

204 See Libya and War Powers: Hearing Before S. Comm. on Foreign Relations, I I 2 th Cong. I4 (June 28, 20II) [hereinafter Libya Hearings] (statement of Harold Hongju Koh, Legal Adviser, Dep't of State).

205 See supra section I.B.I, pp. 424-28.

206 See Morrison, supra note 64, at $1455-56$.

207 See id. at I497-I504 (arguing that OLC appropriately accords special precedential weight to its opinions addressing executive power issues, especially when others in the executive branch 
The harder question is whether the executive branch can justifiably claim that other actors should give its past practices constitutional weight in the absence of congressional acquiescence. As Koh suggested in his earlier capacity as a law professor, the risk of self-dealing might well counsel against privileging such practices. ${ }^{208}$ Still, we think there are plausible grounds for even nonexecutive actors to credit patterns of executive practice, at least in some circumstances. Resorting to such practice can be a way of demonstrating that the executive branch's position today is not driven simply by the political expediencies of the moment. Relatedly, this practice can help support a claim that the Executive's interpretation of the Constitution is supported by recurring functional considerations that have been salient at least to multiple occupants of the Oval Office. Moreover, the very durability of the practice may suggest that it is at least minimally workable. These arguments become stronger when the practice in question is more longstanding and when it reflects the views of both Democratic and Republican administrations. ${ }^{209}$ Of course, even in those circumstances, there is some danger of executive self-dealing. Self-dealing is also a risk, however, when the Supreme Court relies on its own past decisions to resist legislative or executive incursions on judicial power, yet such resistance is not generally thought to be illegitimate. ${ }^{210}$ In both the executive and judicial branches, the appeal to past practice is designed in part to reassure audiences that the legal position in question reflects a good faith judgment shared by institutional occupants over time. ${ }^{211}$

\footnotetext{
have acted in reliance on those opinions); see also Powell, supra note 87, at 536 ("From an executive branch perspective, therefore, presidential assertions of authority, and executive branch legal opinions interpreting the Constitution, are legal authorities that shape the contours within which lawyers should address constitutional issues - especially in the areas of foreign affairs and national security where there is relatively little judicial precedent.”).

$208 \mathrm{KoH}$, supra note 87 , at 70 ("[A]ccommodations between two or more branches ... carry greater normative weight than self-serving justifications that one branch may offer, without another branch's endorsement, to defend its own actions as constitutional.").

209 For somewhat similar reasons, the Supreme Court has stated that, when interpreting a federal statute administered by an administrative agency, it "will normally accord particular deference to an agency interpretation of 'longstanding' duration." Barnhart v. Walton, 535 U.S. 2 I 2 , 220 (2002) (quoting N. Haven Bd. of Educ. v. Bell, 456 U.S. 5I 2,522 n.I 2 (I982)).

210 Cf. Trevor W. Morrison, Constitutional Avoidance in the Executive Branch, 106 Colum. L. REV. I I89, I233-34 (2006) (describing certain Supreme Court uses of the canon of constitutional avoidance to resist legislation potentially stripping federal courts of jurisdiction, and arguing that, "[i]f it is permissible for courts to employ avoidance for such [self-protective] purposes, it seems appropriate to grant the executive branch that option as well").

211 See Harold H. BRUfF, BAD Advice: Bush's LaWyers in the War on TerRor 8I (2009) ("This reliance on the judicial principle of stare decisis [by OLC] constrains decision and gives opinions a life beyond the political administration in which they are generated, creating a body of law within the executive branch that endures."); cf. Stuart Minor Benjamin, Bootstrapping, LAW \& CONTEMP. PROBS., Summer 2012, at II5, I30 ("[O]nce they have some ability to shape their agenda and some ability to exercise volition in reaching their conclusions, actors have
} 
We have focused in this section on arguments by the executive branch that rely on past executive practice, but we could say similar things about congressional appeals to past legislative practice. In part for the reasons set forth in section II.B, the executive branch is more likely than Congress to be consistently attentive to and protective of its practices. But to the extent Congress does appeal to its past practices to defend present exercises of authority, we think the general considerations outlined in this section apply.

\section{CASE STUdies}

In this Part, we present three case studies: on war powers, executive agreements, and removal of executive officers. In each, we describe the role that arguments from historical practice have played in debates over the distribution of authority in these areas, and we assess some of the key features of those arguments. This Article is primarily conceptual rather than empirical, and we do not claim that our case studies are perfectly representative of the role of historical practice in the separation of powers context. At the same time, our case studies cover three important areas of constitutional law, and in that sense they highlight the general significance of practice-based argumentation. They also illustrate some of the specific conceptual and theoretical points discussed in Part III.

\section{A. War Powers}

The first case study concerns the President's authority to initiate the use of military force. The Constitution assigns a variety of warrelated powers to Congress, including the power to declare war. ${ }^{212}$ It also makes the President the Commander in Chief of the armed forces. ${ }^{213}$ Scholars have long debated the implications of these assignments of authority, and in particular whether the President is required by the Constitution to obtain congressional authorization before initiating the use of military force. That debate - the extent of the President's power to direct the use of military force without advance congressional authorization - often features competing claims about historical practice. ${ }^{214}$

the ability to aggrandize their power through bootstrapping. The degree of that ability differs for Justices versus members of Congress and the President, but it is far from clear that this difference in degree translates into a dispositive difference in the approach one should take to their bootstrapping.").

212 U.S. CONST. art. I, § 8, cl. 2 .

213 Id. art. II, § 2, cl. I.

214 See, e.g., Spiro, supra note 86, at I355 ("Ultimately, war powers law does not lend itself to refined parchment solutions. It is rather the 'court of history,' an accretion of interactions among the branches, that gives rise to basic norms governing the branches' behavior in the area."); 
One position, favored by many scholars, is that Presidents are constitutionally required to obtain congressional authorization for any use of military force, except when directly responding to an attack. Proponents of this position place particular emphasis on the original understanding of the Constitution. ${ }^{215}$ At the opposite end of the spectrum, some claim that the President has essentially unlimited constitutional authority to order the use of military force unilaterally. Although some in this latter camp appeal to alternative accounts of the original understanding, they also frequently emphasize post-Founding historical practice. Specifically, they contend that whatever the Founders thought about the distribution of war powers, a longstanding practice of unilateral presidential warmaking has emerged since the Founding, especially after World War II. That practice, they argue, involves not only repeated unilateral presidential uses of military force but also congressional acquiescence in that practice - both in specific instances by failing to override the President and by appropriating needed funds, and more generally by authorizing and funding a large standing military. ${ }^{216}$ As Professor Henry Monaghan maintained more than forty years ago in the midst of debate over the Vietnam War, "this historical development of our institutions has settled the legitimacy of 'inherent' presidential power to commit the armed forces to hostilities." 217

Others have suggested an intermediate position that also relies on historical practice but that draws a somewhat different lesson from it. According to this view, historical practice supports a unilateral presidential authority to engage in "small" or "limited" wars that are not expected to involve substantial or protracted troop commitments, especially on the ground, but not a presidential power to carry out large-

Stromseth, supra note 5, at 873 ("Arguments invoking historical practice play ... a central role in modern debates over war powers ....”).

215 See, e.g., Ely, supra note 86, at 3 (arguing that the original understanding of the Constitution was that "all wars, big or small, 'declared' in so many words or not ... had to be legislatively authorized" (footnote omitted)); FISHER, supra note 5, at 4 ("On numerous occasions the delegates to the constitutional convention emphasized that the power of peace and war ... would not be given to the President."); Francis D. Wormuth \& Edwin D. Firmage, To Chain the DOG OF WAR I8 (2d ed. I989) (discussing the debate over the Declaration of War Clause at the Constitutional Convention and recognizing that "[t]he power to initiate war was left to Congress"); Charles A. Lofgren, War-Making Under the Constitution: The Original Understanding, 8I YALE L.J. 672, 679 (1972) (describing the drafting of the Declaration of War Clause and noting that "war-making fell almost automatically to Congress"); William Michael Treanor, Fame, the Founding, and the Power to Declare War, 82 CORNELl L. REV. 695, 699 (I997) (offering "an explanation for why the Founders would have wanted Congress alone to have the power to start war").

216 See generally Monaghan, supra note 8; Robert F. Turner, Truman, Korea, and the Constitution: Debunking the "Imperial President" Myth, I9 HARV. J.L. \& PUB. POL'Y 533 (I996); John C. Yoo, Applying the War Powers Resolution to the War on Terrorism, 6 GREEN BAG 2D I75 (2003).

217 Monaghan, supra note 8, at $3 \mathrm{I}$. 
scale, prolonged military operations. ${ }^{218}$ Supporters of this view note, for example, that of the five most significant (in time and resources) military conflicts that the United States has been involved in since World War II - the Korean War, the Vietnam War, the two Iraq wars, and the Afghanistan war - only the Korean War lacked congressional authorization, and in that war congressional leaders from both parties publicly endorsed President Truman's commitment of troops. ${ }^{219}$

Supporters of this intermediate position cite the 1973 War Powers Resolution $^{20}$ as evidence of congressional acquiescence to the President's unilateral power to engage in certain "small" military operations. As discussed below, the Resolution states and attempts to implement substantial limits on the President's authority to commit U.S. troops to military operations. Yet OLC and some commentators have construed certain passages in the Resolution as also recognizing a measure of unilateral presidential power in this area. They point in particular to the Resolution's requirement that Presidents either obtain congressional authorization within sixty days of introducing armed forces into hostilities, or cease the operation. ${ }^{221}$ This provision, they claim, implicitly accepts a unilateral presidential authority to initiate military conflicts for less than sixty days in at least some circumstances. ${ }^{222}$

Before evaluating these competing claims, it is useful to consider two relatively uncontroversial practice-based claims relating to war powers. First, the fact that the United States has not issued a declaration of war since World War II, and has issued declarations in connection with only five conflicts in U.S. history, is broadly understood to support the idea that congressional authorizations to use military force

218 See, e.g., Louis Henkin, War Powers “Short of War," 50 U. MIAMI L. REV. 20I, 204 (I995) ("History shows that Presidents have exercised authority to engage in 'little wars,' to deploy forces 'short of war,' in a number of cases - a goodly number - of differing importance.").

219 See, e.g., Curtis A. Bradley \& Jack L. Goldsmith, Congressional Authorization and the War on Terrorism, I 8 HARV. L. REV. 2047, 2060 (2005) (listing military engagements in which Congress authorized the use of military force without declaring war); Turner, supra note 216 , at 568 69 (noting that "congressional leaders unanimously supported [Truman's] actions").

22050 U.S.C. $\S \S$ I 54 I-I 548 (2006).

221 Id. § I544. The sixty-day limit can be extended to ninety days under certain circumstances. Id.

222 See, e.g., Krass Memorandum, supra note 3, at 8-9 ("By allowing United States involvement in hostilities to continue for 60 or 90 days, Congress signaled in the [War Powers Resolution] that it considers congressional authorization most critical for "major, prolonged conflicts such as the wars in Vietnam and Korea,' not more limited engagements." (quoting Deployment of U.S. Armed Forces into Haiti, I8 Op. O.L.C. I73, I76 (1994))); Deployment into Haiti, I8 Op. O.L.C. at I7576 ('[T]he structure of the War Powers Resolution ('WPR') recognizes and presupposes the existence of unilateral presidential authority to deploy armed forces ...."); $c f$. Jack Goldsmith, War Power: The President's Campaign Against Libya is Constitutional, Slate (Mar. 2I, 20I I, 6:48 PM), http://www.slate.com/id/2288869/ ("The WPR ... acknowledge[s] an inherent presidential power to use military force within that [sixty-day] window."). 
that do not take the form of a declaration are constitutionally sufficient for the United States to engage in even significant armed conflicts. ${ }^{223}$ Second, the general consensus that Presidents have some unilateral constitutional authority to use military force to protect or rescue U.S. citizens abroad is based in large part on historical practice and understandings. ${ }^{224}$

A number of factors help explain why historical practice in these two areas has yielded a relatively stable, uncontroversial consensus. First, in neither context has there been significant resistance from Congress as an institution. This lack of resistance is not surprising for the first example, since permitting statutory authorizations to supplant declarations does not yield presidential unilateralism. It merely expands the forms through which Congress can exercise its authority in this area. As for the power to protect or rescue U.S. citizens abroad, if members of Congress insisted that the President needed advance congressional authorization for such actions, they would risk appearing indifferent to the plight of fellow citizens in imminent danger. ${ }^{225}$ For the same reason, Congress would probably authorize such a protective response if it were asked in time, so the executive practice in this area is unlikely to diverge from majority congressional preferences. ${ }^{226}$

A second factor that helps to explain the practice-based consensus on these two issues is that functional considerations support both practices. In the late eighteenth century, declarations of war served specific purposes under international law, wholly apart from their domestic legal effect. ${ }^{227}$ But that specific role has largely disappeared, taking

\footnotetext{
223 See, e.g., Bradley \& Goldsmith, supra note 219 , at 2059-60; Sunstein, supra note 8, at 38990.

224 See, e.g., FISHER, supra note 5, at 44 ("Although the Constitution does not expressly direct the President to protect American life and property in foreign countries, Presidents have sent U.S. forces abroad for that purpose on many occasions."); McGinnis, supra note 8I, at 3I 7 ("[T]here is substantial historical precedent for unilateral executive action in this regard ...."); Stromseth, supra note 5, at 882 ("The second category of historical practice that meets the Frankfurter standard, in my judgment, is the longstanding presidential practice of using limited force to rescue American citizens abroad whose lives are in imminent danger.").

225 The authority to protect U.S. citizens abroad is not mentioned in section 2(c) of the War Powers Resolution, but some of the key congressional supporters of the Resolution later conceded that such an authority should have been included. See ELY, supra note 86, at ir7. Of course, there are sometimes debates about the scope of this authority.

226 In the few instances in recent years in which Congress has imposed funding cutoffs for U.S. military operations, such as in Somalia and Rwanda, it has included an exception for the protection of U.S. personnel and citizens. See Richard F. GRIMmett, CONG. RESEARCH SERV., RS20775, CONGRESSIONAL USE OF FUNDING CUTOFFs SinCE I970 INVOLVING U.S. MiliTARY FORCES AND OVERSEAS DEPLOYMENTS 3 (2007), available at http://assets.opencrs.com /rpts/RS20775_20070I I6.pdf.

227 See generally Saikrishna Bangalore Prakash, Exhuming the Seemingly Moribund Declaration of War, 77 GEO. WASH. L. REV. 89, 107-20 (2008) (cataloguing Founding-era understandings of the different functions of a declaration of war).
} 
with it the functional reason for granting them special constitutional status. ${ }^{228}$ Similarly, the modern reality that there are U.S. troops and other citizens in virtually all parts of the world, and that they are exposed to a wide range of threats, makes it not only politically unpalatable but also practically unworkable to insist on advance congressional authorization before the executive branch takes protective action.

On the scope of the President's authority to initiate military conflicts without congressional authorization, however, there is much less agreement about how to characterize the historical practice. Prior uses of force have varied along numerous dimensions - such as duration, risk to U.S. forces, connection to U.S. national security interests, and level of international support - often making it debatable whether a given action in the present falls within past precedents. ${ }^{229}$ Our focus here is on a different problem: the difficulty in knowing what constitutes institutional acquiescence in this context, especially on the part of Congress.

Consider in this regard the 20I I OLC opinion finding that President Obama had the constitutional authority to direct use of U.S. military force against the Qaddafi regime in Libya, even though Congress had not authorized such force. ${ }^{230}$ The opinion relied heavily on claims about historical practice to defend a view largely in line with the intermediate position described above. In addition to quoting a I980 OLC opinion that described history as "replete with instances of presidential uses of military force abroad in the absence of prior congressional approval," ${ }^{231}$ OLC provided more recent examples of such uses of force:

Since then, instances of such presidential initiative have only multiplied, with Presidents ordering, to give just a few examples, bombing in Libya (1986), an intervention in Panama (I989), troop deployments to Somalia (I992), Bosnia (I995), and Haiti (twice, I994 and 2004), air patrols and airstrikes in Bosnia (I993-I995), and a bombing campaign in Yugoslavia (I999), without specific prior authorizing legislation. ${ }^{232}$

228 See Bradley \& Goldsmith, supra note 2 I9, at 206 I-62.

229 The proper characterization of past uses of force, then, is a specific example of the general issue of scope noted in section I.A. See supra pp. 423-24. For a list of hundreds of instances in which the United States has used military force abroad since the Founding, see RICHARD F. Grimmett, Cong. Research Serv., R4i677, Instances of Use of United States ARMED FORCES ABROAD, I798-20IO (20II), available at http://www.fas.org/sgp/crs/natsec /R4I677.pdf.

230 Krass Memorandum, supra note 3.

231 Id. at 7 (quoting Presidential Power to Use the Armed Forces Abroad Without Statutory Authorization, 4A Op. O.L.C. I85, I87 (1980)) (internal quotation mark omitted).

232 Id. 
As noted above, ${ }^{233}$ OLC also conceded that Presidents might be constitutionally required to seek congressional authorization for "prolonged and substantial military engagements, typically involving exposure of U.S. military personnel to significant risk over a substantial period." 234 But it claimed that the historical practice reflected a shared "practical understanding" between Congress and the Executive that Presidents have the authority to order the use of military force in circumstances comparable to the above-mentioned past precedents. ${ }^{235}$

Yet if one's approach to historical practice focuses on claims of institutional acquiescence, mere recitations of operationally similar past uses of force should not suffice. There should also be some inquiry into Congress's response. That inquiry complicates at least some of the precedents that OLC relied upon in its Libya opinion. For example, although the bombing campaign against Serbia in the late I99os relating to atrocities in Kosovo was similar to the Libya campaign as an operational matter, there was substantial congressional opposition to the Kosovo campaign. ${ }^{236}$ Similarly, although there are some parallels between the Libya operation and President Clinton's dispatch of U.S. troops to Haiti in 1994, Congress responded to that action by passing a joint resolution expressing a "sense of Congress" that "the President should have sought and welcomed Congressional approval before deploying United States Armed Forces to Haiti."237 The President even signed that resolution. ${ }^{238}$ These precedents would thus seem to offer little if any support to OLC's acquiescence-based claims in its Libya opinion. ${ }^{239}$

\footnotetext{
233 See supra p. 454.

234 Krass Memorandum, supra note 3, at 8; see also id. (describing such a conflict as "a planned military engagement that constitutes a 'war' within the meaning of the Declaration of War Clause").

235 Id. at 7.

236 A bill that would have authorized the campaign was defeated in the House of Representatives on a tie vote of 2I3-2I3. See Campbell v. Clinton, 203 F.3d I9, 20 (D.C. Cir. 2000). Somewhat similar opposition developed with respect to the Libya campaign, especially after the expiration of the War Powers Resolution's sixty-day period for obtaining congressional authorization. A resolution that would have authorized the Libyan operations was defeated in the House on a vote of 295-I23, and a resolution that would have disallowed the use of ground forces in Libya passed the House on a vote of 268-I45. See Richard F. Grimmett, Cong. Research Serv., RL33532, WAR POWERS ReSOlution: PRESIDENTIAL COMPLIANCE I3, I4 (20I2), available at http://www.fas.org/sgp/crs/natsec/RL33532.pdf.

237 Joint Resolution Regarding United States Policy Toward Haiti, Pub. L. No. I03-423, I08 Stat. 4358 (I994).

238 Statement on Signing Legislation on United States Policy on Haiti, 30 WeEkLY CoMP. PRES. DOC. 2 I 84 (Oct. 25, I 994).

239 For a criticism of OLC's Libya opinion on this and related grounds, see Michael J. Glennon, The Cost of "Empty Words": A Comment on the Justice Department's Libya Opinion, HARV. NAT'L SEC. J. F. (20II), http://harvardnsj.com/wp-content/uploads/20I I/o4/Forum_Glennon _Final-Version.pdf.
} 
More broadly, any claim of congressional acquiescence in this area needs to take account of the War Powers Resolution - and not just the sections that some commentators construe as accepting a certain measure of unilateral presidential authority. ${ }^{240}$ As discussed in section II.B, Congress faces numerous institutional obstacles to acting in a unified way to protect its constitutional prerogatives. Yet Congress overcame those obstacles in passing the Resolution, which in its core provisions asserts that the President is constitutionally required to obtain congressional authorization before introducing U.S. forces into hostilities (or situations in which hostilities are imminent) unless he is responding to an attack on the United States, its territories or possessions, or its armed forces. ${ }^{241}$ Presidents have disputed this assertion, ${ }^{242}$ but Congress has not repealed or amended the Resolution ${ }^{243}$ and has, in fact, consistently referenced the Resolution in its authorizations of force. ${ }^{244}$ Furthermore, the executive branch has on occasion stated that it accepts or at least does not actively contest the constitutionality of the Resolution's sixty-day cutoff provision. ${ }^{245}$

\footnotetext{
240 See supra p. 463.

241 See Pub. L. No. 93-I48, §2(c), 87 Stat. 555, 555 (I973) (codified at 50 U.S.C. § I54I(c) (2006)).

242 See Overview of the War Powers Resolution, 8 Op. O.L.C. 27 I, 274 (I984) ("The Executive Branch has taken the position from the very beginning that $\S_{2}$ (c) of the [War Powers Resolution] does not constitute a legally binding definition of Presidential authority to deploy our armed forces.").

243 In I995, the House of Representatives defeated, by a vote of 2 I 7-20I, a bill that would have deleted most of the key elements of the Resolution. See GRImmetr, supra note 236, at 23.

244 For example, in its 2002 joint resolution approving the use of military force against Iraq, Congress stated that the resolution "is intended to constitute specific statutory authorization within the meaning of section 5(b) of the War Powers Resolution" and that "[n]othing in this joint resolution supersedes any requirement of the War Powers Resolution." Authorization for Use of Military Force Against Iraq Resolution of 2002, Pub. L. No. 107-243, § 3(c), I I6 Stat. I498, I50I.

245 See Presidential Power to Use the Armed Forces Abroad Without Statutory Authorization, 4A Op. O.L.C. I85, I96 (I980) ("The practical effect of the 60-day limit is to shift the burden to the President to convince the Congress of the continuing need for the use of our armed forces abroad. We cannot say that placing that burden on the President unconstitutionally intrudes upon his executive powers."); Libya Hearings, supra note 204, at 53 (statement of Harold Hongju Koh, Legal Adviser, Dep't of State) (confirming that the position expressed in the r 980 OLC memorandum "continues to reflect the views of the executive branch"). On other occasions executive officials have been more equivocal. See, e.g., H. Con. Res. 82, Directing the President to Remove Armed Forces from Operations Against Yugoslavia, and H.J. Res. 44, Declaring War Between the United States and Yugoslavia: Markup Before the H. Comm. on Int'l Relations, Io6th Cong. 3233 (I999) (statement of Barbara Larkin, Assistant Sec'y of State) ("This Administration, like previous Administrations, takes the view that the President has broad authority as Commander-inChief, and under his authority to conduct foreign relations, to authorize the use of force in the national interest."); id. at 37 (statement of Michael Matheson, Principal Deputy Legal Adviser, Dep't of State) ("This Administration has not taken a formal stance on the constitutionality of the 6o-day provision to this point, but has taken the view that it is unwise and should be repealed."). On still other occasions executive officials have seemed to oppose the idea that the Resolution lawfully constrains the President's authority. See, e.g., Yoo, supra note 2 I6, at I75 ("[T]he Presi-
} 
At the same time, Congress's influence on presidential war powers should not be judged simply by the rare times when it enacts legislation restricting presidential action. ${ }^{246}$ Among other things, taking such a narrow focus risks overlooking instances in which Presidents have refrained from acting, or have altered the nature of their actions, because of anticipated congressional objections. It also leaves out potential means of congressional influence other than formal legislation, such as oversight hearings or direct appeals to the public through the news media. ${ }^{247}$ Particularly in times of divided government, these informal means can have a substantial influence on presidential decisionmaking relating to war. ${ }^{248}$

\section{B. Congressional-Executive Agreements}

Article II of the Constitution provides that the President has the power to make treaties "by and with the advice and consent of the Senate ... provided two thirds of the Senators present concur."249 This language might suggest that Presidents may constitutionally enter into binding international agreements only by obtaining Senate supermajority approval. Yet Presidents have long concluded some international agreements by other means. While these "executive agreements" were relatively rare early in U.S. history, today they constitute the vast majority of international agreements entered into by the United States. ${ }^{250}$ In this section, we consider the constitutional issues relating to "congressional-executive agreements" — that is, executive agreements concluded with the ex ante or ex post approval of a majority of

dent's power to engage U.S. Armed Forces in military hostilities is not limited by the War Powers Resolution.").

246 See Howell \& Pevehouse, supra note I63, at 23.

247 See id. at 29 (suggesting that Congress can "us[e] the media to air arguments against military action, and by underscoring the risks involved, [it] may temper any rally effects the president would otherwise enjoy"). A particularly vivid example, relating not to the decision whether to commence a military operation but to the decision whether and how to continue one, is Senator Gravel's decision, before the Supreme Court handed down its decision in the Pentagon Papers case, to release to the public 4100 pages of the Pentagon Papers - substantially more than the newspapers ever ultimately published. See Chafetz, supra note 156 , at $745-50$ (discussing this episode).

248 See Howell \& Pevehouse, supra note $\mathrm{I} 63$, at 222 ("Modern presidents consistently heed the distinctly political threat posed by large, cohesive, and opposing congressional majorities ....").

249 U.S. CONST. art. II, § 2, cl. 2.

250 In the first fifty years of its constitutional history, the United States concluded sixty treaties and only twenty-seven executive agreements. Between 1939 and I989, however, it concluded over i I,000 executive agreements and only about 700 treaties. See CONG. Research Serv., ro6th Cong., Treaties and Other International Agreements: The Role of the United States Senate 39 (Comm. Print 200I) [hereinafter CRS TREaty Study]. 
each house of Congress. ${ }^{251}$ Compared to the war powers area, here Congress has been a much more active participant in the historical practice in question.

There have been congressional-executive agreements since early in U.S. history. In I 792, Congress authorized the Postmaster General to conclude international agreements concerning the exchange of mail. ${ }^{252}$ Congressional-executive agreements have been especially common in the area of international trade, in part because of the perception that this area falls within the prerogatives of the full Congress to regulate foreign commerce and raise revenues. ${ }^{253}$

The number of congressional-executive agreements rose dramatically in the twentieth century. ${ }^{254}$ The establishment of the United Nations at the end of World War II prompted a substantial growth in international agreements, and the increased global role of the United States during and after the war prompted greater U.S. involvement in such agreements. Globalization also revealed, and in many instances created, problems that could be addressed effectively only through international cooperation. The executive branch found it much easier to conclude international agreements by seeking the approval of a majority of Congress rather than that of two-thirds of the Senate.

It is generally accepted today that congressional-executive agreements are at least sometimes constitutional. The dispute is instead over the extent to which they are interchangeable with Article II treaties, and the various positions on the issue tend to rely heavily on claims about historical practice. As with war powers issues, judicial review of claims involving congressional-executive agreements is unlikely. ${ }^{255}$ Instead, the principal contributions to the interchangeability

251 The other two types of executive agreements are those concluded by the President pursuant to authority granted in an Article II treaty, and "sole executive agreements" concluded by the President based on his own constitutional authority. Congressional-executive agreements are by far the most common type of executive agreement. See R. Roger MAJAK, Cong. RESEARCH Serv., 95TH Cong., International Agreements: An AnAlysis of Executive ReguLATIONS AND PRACTICES 22 (Comm. Print i977).

252 See Act of Feb. 20, I 792, ch. 7, § 26, I Stat. 232, 239. In arguing many years later that the postal agreements were constitutional, then-Solicitor General William Howard Taft reasoned that, "where long usage, dating back to a period cotemporary with the adoption of the Constitution, sanctions an interpretation of that instrument different from that which would be reached by the ordinary rules of construction were the question a new one, the usage will be followed." Postal Conventions with Foreign Countries, ig Op. Att'y Gen. 5 I3, 5 I 5 (I890).

253 See Jeanne J. Grimmett, Cong. Research Serv., 97-896, Why Certain Trade AgreEments ARE ApProved as CongressionAl-ExeCutive AGreEments RATHER THAN AS TREATIES 2 (2004), available at http://fpc.state.gov/documents/organization/35430.pdf; Detlev F. Vagts, Editorial Comment, The Exclusive Treaty Power Revisited, 89 AM. J. INT'L L. 40, 4I (I995).

254 See CRS TREATY STUDY, supra note 250 , at 40-4I.

255 See, e.g., Made in the USA Found. v. United States, 242 F.3d I300, I3 I9-20 (I Ith Cir. 200I) (holding that "in the context of international commercial agreements such as NAFTA - given the 
debate have come from the political branches themselves, as well as from scholarly commentary. And many of those contributions have focused on historical practice. In defending the use of a congressionalexecutive agreement to join the World Trade Organization, for example, OLC began by noting that "a significant guide to the interpretation of the Constitution's requirements is the practical construction placed on it by the executive and legislative branches acting together."256 OLC then argued that "practice under the Constitution has established that the United States can assume major international trade obligations such as those found in the Uruguay Round Agreements when they are negotiated by the President and approved and implemented by Act of Congress." 257

Scholars are divided over the extent of interchangeability between Article II treaties and congressional-executive agreements. The $R e$ statement (Third) of Foreign Relations Law contends that "[t]he prevailing view is that the Congressional-Executive agreement can be used as an alternative to the treaty method in every instance." 258 Professor Louis Henkin (who served as Chief Reporter for the Restatement) similarly argued that "it is now widely accepted that the Congressional-Executive agreement is available for wide use, even general use, and is a complete alternative to a treaty."259

In the mid-I990s, Professors Bruce Ackerman and David Golove published a lengthy article arguing in favor of full interchangeability. ${ }^{260}$ While contending that such interchangeability is not supported by the pre-World War II historical practice, they argued that it is nevertheless consistent with modern constitutional law because of what they characterized as an informal amendment to the Constitution in

added factor of Congress's constitutionally-enumerated power to regulate commerce with foreign nations, as well as the lack of judicially manageable standards to determine when an agreement is significant enough to qualify as a 'treaty' - the issue of what kinds of agreements require Senate ratification pursuant to the Art. II, $\S 2$ procedures presents a nonjusticiable political question”).

256 Whether Uruguay Round Agreements Required Ratification as a Treaty, I8 Op. O.L.C. 232, 233 (I 994).

257 Id. at 234; see also Memorandum from Walter Dellinger, Assistant Att'y Gen., Office of Legal Counsel, to Ambassador Michael Kantor, U.S. Trade Representative, Re Whether the GATT Uruguay Round Must be Ratified as a Treaty (July 29, I994), reprinted in I40 CONG. REC. I 9,492, I 9,494 n.5 (I994) ("[T] the ordinary procedures of bicameral passage and presentment to the President offers significant support for the conclusion that it is sufficient here.").

258 RESTATEMENT (THIRD) OF THE Foreign RELATIONS LAW OF THE UNited States $\S 303$, cmt. e (I 987$)$.

259 Henkin, supra note 72 , at 2 I 7 (footnote omitted). In a footnote, Henkin added the qualification that "doubts might spark if it were used for an agreement traditionally dealt with by treaty and that seems to ask for the additional 'dignity' of a treaty, for example, a major alliance or disarmament arrangement." Id. $\mathrm{n}$.*.

260 See Bruce Ackerman \& David Golove, Is NAFTA Constitutional?, Io8 HARV. L. REv. 799, 805 (I 995). 
the mid-I940s. ${ }^{261}$ That argument drew on Ackerman's broader theory of "constitutional moments," 262 which has proven controversial. ${ }^{263}$ But the important point for present purposes is that Ackerman and Golove's claim about this particular "amendment" depended on establishing that it has been borne out by post-World War II practice. ${ }^{264}$

Professor Laurence Tribe vigorously critiqued Ackerman and Golove's account, both in terms of its general interpretive approach and for the implications it drew from the post-World War II practice. ${ }^{265}$ While acknowledging that "post-adoption history has a role in constitutional interpretation," Tribe contended that "an argument based primarily on congressional practice should rarely be persuasive unless that practice extends back to our nation's founding, rather than being adopted as a conscious end-run around constitutional requirements."266 In doing so he relied heavily on the Supreme Court's decision in INS v. Chadha, which, as discussed above, held the legislative veto unconstitutional despite longstanding congressional practice. ${ }^{267}$ In a memorandum addressed to top executive branch lawyers and Senate leaders, Tribe further argued that "falling into the habit of using congressionalexecutive agreements in place of the constitutionally designated treaty process did not reflect a reasoned judgment by national leaders that such action is envisioned by the Constitution."268

261 Id. at $873-74,896$.

262 For articulations of the constitutional moments theory, see I BRUCE ACKERMAN, WE THE People: Foundations 266-94 (i99i); 2 Bruce Ackerman, We the People: TransFORMATIONS 3-3I (I998).

263 For critiques of the theory, see, for example, Richard A. Posner, Overcoming Law 2 I5-28 (I995); Michael J. Gerhardt, Ackermania: The Quest for a Common Law of Higher Lawmaking, 40 WM. \& MARY L. REV. I73I (I999) (book review); Michael J. Klarman, Constitutional Fact/Constitutional Fiction: A Critique of Bruce Ackerman's Theory of Constitutional Moments, 44 Stan. L. Rev. 759 (1992) (book review); Suzanna Sherry, The Ghost of Liberalism Past, ro5 HARV. L. REV. 9I8 (I992) (book review).

264 See Ackerman \& Golove, supra note 260, at 897 (recognizing this burden and contending that, "[o]ver the next half-century, Congress consolidated these precedents by passing statutes that used the congressional-executive agreement as a tool for the control of foreign policy"); Letter from Bruce Ackerman, Professor, Yale Law Sch., and David Golove, Professor, Univ. of Ariz. Coll. of Law, to President William Clinton 3 (Sept. 2 I, I994), quoted in Laurence H. Tribe, Taking Text and Structure Seriously: Reflections on Free-Form Method in Constitutional Interpretation, I08 HARV. L. REV. I22 I, I280 (I995) ("After a half-century of successful use of the CongressionalExecutive Agreement, it is far too late to question Congress' powers under Article [I].").

265 See Tribe, supra note 264 , at I223-28.

266 Id. at $\mathrm{I} 280$.

267 See id. at I28I; see also GATT Implementing Legislation: Hearings on S. 2467 Before the S. Comm. on Commerce, Sci., \& Transp., Io3d Cong. 299 (1994) (statement of Laurence H. Tribe, Professor, Harvard Law Sch.) ("What the text of the Treaty Clause will not permit cannot be validated by so-called congressional 'precedent.'”).

268 Memorandum from Laurence H. Tribe, Professor, Harvard Law Sch., to Walter Dellinger et al., The Constitutional Requirement of Submitting the Uruguay Round as a Treaty 6-7 (Oct. 5, I994) (on file with the Harvard Law School Library). 
Other scholars writing about congressional-executive agreements have, like Tribe, eschewed Ackerman's theory of constitutional moments. Many of these scholars give greater interpretive weight to modern historical gloss than Tribe does. But they read the relevant history differently than do Ackerman and Golove. In particular, they argue that the relevant practice establishes some limits on congressionalexecutive agreements' permissible use. ${ }^{269}$ In a recent contribution to this debate, Professor Oona Hathaway presents the most detailed empirical study to date of the use of both Article II treaties and congressional-executive agreements. ${ }^{270}$ Her findings generally accord with earlier claims that the historical practice does not support full interchangeability. ${ }^{271}$ She argues, however, that the patterns in the practice are the product of historical compromises and anachronisms rather than legally sensible distinctions. ${ }^{272}$ Hathaway therefore advocates a shift toward something close to full interchangeability, not because it is supported by historical practice, but because partial interchangeability, in her view, is not a principled or conceptually stable position and undermines the reliability of international commitments. ${ }^{273}$

Part of the debate over the interchangeability of treaties and congressional-executive agreements involves questions of institutional acquiescence. Proponents of broad interchangeability tend to place great weight on claims of acquiescence. OLC, for example, grounds its account of the permissibility of congressional-executive agreements in a claim about historical practice, which OLC says deserves constitutional weight because it represents "the considered constitutional

269 See, e.g., Spiro, supra note 5, at 996-1002 (contending that the post-World War II practice does not support full interchangeability for agreements in the areas of arms control and human rights); John C. Yoo, Laws as Treaties?: The Constitutionality of Congressional-Executive Agreements, 99 MICH. L. REV. 757, 800 (200I) ("Customary practice indicates that the political branches have observed discernable lines in the use of these instruments of national policy.”).

270 See Oona A. Hathaway, Treaties' End: The Past, Present, and Future of International Lawmaking in the United States, I 7 YALE L.J. I236, I252-54 (2008).

271 See id. at I239-40.

272 Id. at 1306.

273 Id. at I24I. However, Hathaway also concludes that Article II treaties are still required for issues that fall outside Congress's Article I authority. See id. at I339. Under the Supreme Court's decision in Missouri v. Holland, $25^{2}$ U.S. 4I6 (1920), Article II treaties may regulate issues Congress cannot reach by legislation. Like a number of other scholars, Hathaway assumes that this decision does not apply to congressional-executive agreements, which are premised in part on Congress's Article I authority and do not involve the same process protection for federalism provided by the Article II requirement of supermajority senatorial consent. See Hathaway, supra note $27 \mathrm{O}$, at $\mathrm{I} 339$; see also, e.g., Bradford R. Clark, Separation of Powers as a Safeguard of Federalism, 79 TEX. L. REV. I32I, I442 (200I) ("If Missouri v. Holland is correct that the treatymaking power exceeds Congress's lawmaking power, then treaties and congressional-executive agreements are not interchangeable." (footnote omitted)); David Sloss, International Agreements and the Political Safeguards of Federalism, 55 STAN. L. REV. I963, I995 (2003) ("[C]ongressionalexecutive agreements should be subject to the same judicially enforced federalism limitations as ordinary legislation."). 
judgments of the political branches" 274 and because this is "an area where the sound judgment of the political branches, acting in concert and accommodating the interests and prerogatives of one another, should be respected." 275 Acquiescence is also part of the story of constitutional change presented by Ackerman and Golove, who contend that congressional-executive agreements became interchangeable with Article II treaties as the result of "Senate surrender . . . accompanied by self-conscious debate." 276 Hathaway, meanwhile, suggests that acquiescence helps explain why a complete shift to interchangeability is politically feasible. ${ }^{277}$

But acquiescence is a difficult concept in this area. Wholly apart from the merits of any particular claim of acquiescence, it is worth thinking carefully about the precise institution whose interests are most infringed - and, thus, the institution whose acquiescence should be most relevant - by the rise of congressional-executive agreements. And although the shift to congressional-executive agreements forces the Senate to share the treaty-approval function with the House, the full Senate does retain a key role in congressional-executive agreements because such agreements still require a Senate majority. Thus, the interests most directly threatened are those of a minority of the Senate large enough to block Article II treaties (one-third of present Senators) but too small to block congressional-executive agreements (one-half). ${ }^{278}$ This fact makes it especially important to look beyond formal enactments and even informal resolutions when considering whether the relevant actors have objected to the practice in question. Yet claims of acquiescence in this area rarely do that.

Even focusing on the Senate as a whole, the claim of acquiescence in full interchangeability is problematic. In certain areas there is, in fact, considerable evidence of nonacquiescence. Arms control is perhaps the best example. Although the 1972 SALT I Interim Agreement was concluded as a congressional-executive agreement, every other major arms control treaty since World War II has been concluded

\footnotetext{
274 Whether Uruguay Round Agreements Required Ratification as a Treaty, I8 Op. O.L.C. 232, 235 (I 994).

275 Id. at 240

276 Ackerman \& Golove, supra note 260 , at 908.

277 Hathaway, supra note 270 , at I 353 (arguing that the Senate "relinquish[ed] its sole power to provide 'advice and consent' in favor of shared authority to approve congressional-executive agreements" when it "repeatedly and with little overt resistance" gave way to this practice in the last half century).

278 Even taking into account the Senate's filibuster practice, minority senators have greater ability to block Article II treaties than to block congressional-executive agreements. See id. at I3I I-I 2 (noting that the filibuster carries political risks and pointing out that the seven-vote difference between the filibuster-proof majority and the Article II supermajority is not trivial).
} 
through the Article II process. ${ }^{279}$ Various political and pragmatic factors likely contribute to this pattern, but constitutionally based insistence by the Senate appears to be part of the story. When giving its advice and consent to a number of other arms control treaties, the Senate has included a declaration stating that agreements "that would obligate the United States to reduce or limit the Armed Forces or armaments of the United States in a militarily significant manner [should be concluded] only pursuant to the Treaty Power as set forth in Article II, Section 2, Clause 2 of the Constitution."280

Ackerman and Golove dismiss such statements as "empty senatorial pronunciamentos," 281 but that characterization gives too little weight to the kinds of soft law discussed in section II.B. ${ }^{282}$ Moreover, this dismissal ignores the fact that the executive branch itself expressly takes account of both historical practice and the wishes of Congress in deciding whether to use congressional-executive agreements. ${ }^{283}$ Legal positions expressed by one political branch can carry great weight with another branch even if they are not formally legally binding. In this case, the Senate's publicly announced constitutional views may well have altered the relative costs and benefits to the executive branch of using one form of agreement rather than the other.

In fact, there is evidence that these "senatorial pronunciamentos" have led Presidents to alter their plans with respect to international agreements. In the late I970s, President Carter considered submitting the SALT II arms control agreement as a congressional-executive agreement but relented in the face of senatorial protests. ${ }^{284}$ In 1997, President Clinton responded to Senate pressure by agreeing to submit an update of the Treaty on Armed Conventional Forces in Europe to the Senate for its advice and consent, thereby abandoning an earlier

279 See Yoo, supra note 269 , at 804-05.

280 Spiro, supra note 5, at 997 (quoting S. ExEC. REP. NO. I02-22, at 8I (I99I))

281 Ackerman \& Golove, supra note 260 , at 903.

282 See supra p. 446; see also Spiro, supra note 5, at 997-98 (observing that Ackerman and Golove's characterization of the senatorial statements "seems to substantially underestimate their significance, as more recent practice is bearing out").

283 The U.S. State Department authorizes the negotiation of international agreements on behalf of the United States pursuant to what is referred to as the "Circular I 75 procedure" (named after a State Department Circular first issued in 1955). See Circular I75 Procedure, U.S. DEP'T OF STATE, http://www.state.gov/s/l/treaty/c I 75 (last visited Oct. 27, 20I2); i I U.S. DEP'T OF STATE, FOREIGN AFFAIRS MANUAL $\S$ 720-727 (2006), available at http://www.state.gov/documents /organization/883 I 7.pdf. In considering the proper form for an international agreement, the State Department looks to eight factors, including "[p]ast U.S. practice as to similar agreements" and "[t]he preference of the Congress as to a particular type of agreement." ForEIGN AFFAIRS MANUAL, supra, § 723.3.

284 See Phillip R. Trimble \& Jack S. Weiss, The Role of the President, the Senate and Congress with Respect to Arms Control Treaties Concluded by the United States, 67 CHI.-KENT L. REV. 645, 66I-62 (I99I). 
decision to seek only majority congressional approval for the agreement. ${ }^{285}$ And after initially suggesting that he might conclude a nuclear weapons reduction agreement with Russia through some sort of executive agreement, President George W. Bush decided to submit the reduction agreement to the Senate for its advice and consent. ${ }^{286}$ Significantly, he acted only after senior Democratic and Republican members of the Senate Foreign Relations Committee told the Secretary of State that because the agreement "would most likely include significant obligations by the United States regarding deployed U.S. strategic nuclear warheads," they were "convinced that such an agreement would constitute a treaty subject to the advice and consent of the Senate." ${ }^{287}$ It is also noteworthy that although President Clinton attempted and ultimately failed to obtain senatorial advice and consent to the Comprehensive Nuclear Test Ban Treaty, ${ }^{288}$ his administration never publicly proposed - nor, so far as we know, even privately contemplated - concluding the treaty as a congressional-executive agreement. When President Obama attempted to resurrect the treaty a decade later, he went back to the Article II process. ${ }^{289}$ If Article II treaties and congressional-executive agreements were understood to be freely interchangeable, this behavior would be difficult to explain.

More generally, outside the areas of trade, commerce, and finance, high-profile international agreements are typically processed as Article II treaties rather than congressional-executive agreements. For example, the United States used the Article II process to ratify the United Nations Charter, the NATO defense agreement, the Geneva Conventions, and the Nuclear Non-Proliferation Treaty. Similarly, all the major human rights conventions ratified by the United States have been processed as Article II treaties. As a comprehensive study prepared for the Senate Foreign Relations Committee in $200 \mathrm{I}$ noted, "[a] perennial concern of Senators has been to insure that the most important international commitments are made as treaties rather than executive agreements." 290

\footnotetext{
285 See Phillip R. Trimble \& Alexander W. Koff, All Fall Down: The Treaty Power in the Clinton Administration, i6 BERKELEY J. INT'L L. 55, 56 (I998).

286 See Curtis A. BRAdley \& JaCK L. Goldsmith, Foreign Relations LaW 589-90 (4th ed. 20II).

287 Id . at 590 (excerpting a letter sent by Sen. Joseph R. Biden, Jr., and Sen. Jesse Helms, the chairman and ranking member, respectively, of the Senate Foreign Relations Committee, to Secretary of State Colin Powell).

288 See David E. Sanger, Clinton Says 'New Isolationism' Imperils U.S. Security, N.Y. TIMES, Oct. I5, I999, at Ar.

289 See David E. Sanger, Obama to Seek Ratification of Nuclear Test Ban Treaty, N.Y. Times, Feb. I9, 2010, at Ais.

290 CRS TREATy STUDY, supra note 250 , at 26 . In I978, the Senate issued the International Agreements Consultation Resolution, which calls for the President to "have timely advice of the
} 
In light of this practice, it seems highly unlikely that the United States would join, say, the International Criminal Court (ICC) treaty through any process other than the one specified in Article II. In fact, Congress has specifically stated that the ICC treaty may not be joined except through the Article II process. ${ }^{291}$ Nor have Presidents apparently contemplated concluding the Law of the Sea Convention as anything other than an Article II treaty, even though they have had great difficulty moving the Convention through that process. ${ }^{292}$ Ultimately, then, the historical practice suggests a constitutionally salient distinction between "major" and "minor" agreements (at least in certain subject areas), which is somewhat akin to the distinction between major and minor armed conflicts in the war powers debate.

\section{Removal of Executive Officers}

Our third case study concerns the power to remove executive officers. It differs from the others in at least three respects. First, it does not particularly concern foreign affairs, and it therefore illustrates how debates over historical practice can inform separation of powers disputes in the domestic arena. Second, it primarily involves questions of executive rather than congressional acquiescence in historical practice. Third, it covers an area in which the courts have played an active role.

Article II of the Constitution grants the President the power to "nominate, and by and with the Advice and Consent of the Senate, [to] appoint... Officers of the United States."293 Yet other than impeachment, ${ }^{294}$ the Constitution contains no express mechanism for the removal of such officers. The key questions are who has the power to remove officers of the United States, what is the basis of that authority, and whether it is subject to limitation.

Much of the constitutional debate concerning these issues is focused on the Constitution's original meaning. Particular emphasis is placed on the so-called "Decision of I 789 ." The context was a bill to create a Department of Foreign Affairs, a proposed provision of which would have granted the President authority to remove the Secretary heading

Committee on Foreign Relations" in determining "whether a particular international agreement should be submitted as a treaty." S. Res. 536, 95th Cong. (1978).

291 See 22 U.S.C. § 740I(a) (2006) ("The United States shall not become a party to the International Criminal Court except pursuant to a treaty made under Article II, section 2, clause 2 of the Constitution of the United States on or after November 29, I999.”).

292 See, e.g., Lauren Morello, U.S. Pushes for Law of the Sea Ratification as New Arctic Mapping Project Begins, N.Y. TIMEs (July 29, 2009), http://www.nytimes.com/cwire/2009/07/29 /2 9 climatewire-us-pushes-for-law-of-the-sea-ratification-as-891 $74 . \mathrm{html}$.

293 U.S. CONST. art. II, § 2, cl. 2.

294 Id. art. II, § 4 . 
the Department. ${ }^{295}$ Some members of the House of Representatives voiced concern that the provision might be taken to imply that the removal power was statutory and not constitutional. A motion was made to delete the provision, ${ }^{296}$ triggering a lengthy debate during which a variety of constitutional views were articulated. ${ }^{297}$ Ultimately, the removal provision was deleted. ${ }^{298}$

There has long been substantial disagreement about the implications of the Decision of I 789 . Some commentators have treated the Decision as embracing a broad and essentially unregulable presidential power, derived from Article II of the Constitution, to remove executive officers. ${ }^{299}$ Others have suggested that the Decision reflects a view that the President may remove executive officers without specific statutory authority, but that it does not resolve whether Congress may reserve to itself any removal authority or impose limits on the President's removal power. ${ }^{300}$ Still others have argued that the Decision cannot plausibly be understood to reflect a settled congressional position on any of these questions. ${ }^{301}$

For a time in the latter half of the nineteenth century, Congress insisted on a direct role for itself in the removal process. The most notable example was the Tenure of Office Act of 1867 , which provided that the Secretaries of State, Treasury, War, Navy, and Interior, as well

295 See I ANNALS OF CoNG. 370-7 I (I789) (Joseph Gales ed., I834) (providing that the Secretary was to be "appointed by the President, by and with the advice and consent of the Senate; and to be removable by the President").

296 See id. at 578-79.

297 See FiSHER, supra note 86, at 49-52.

298 I ANNALS OF CONG. 580 (I789).

299 See, e.g., Alexander Hamilton, Pacificus No. I (I793), reprinted in I 5 THE PAPERS OF ALEXANDER HAMILTON 33, 40 (Harold C. Syrett ed., I969); Saikrishna Prakash, New Light on the Decision of I789, 9I CORNELL L. REV. IO2 I (2006). Those taking this position would do so only for the removal of presidentially appointed officers, not those "inferior officers" whose appointment Congress has permissibly vested in the courts or department heads. See U.S. ConST. art. II, $\S 2$, cl. 2 ("[B] ut the Congress may by Law vest the Appointment of such inferior Officers, as they think proper, in the President alone, in the Courts of Law, or in the Heads of Departments."). The Supreme Court has confirmed that " $[\mathrm{t}]$ he authority of Congress given by the excepting clause to vest the appointment of such inferior officers in the heads of departments carries with it authority incidentally to invest the heads of departments with power to remove." Myers v. United States, 272 U.S. 52, I6I (I926).

300 See, e.g., Manning, supra note 95, at I964-65 n.I35 ("The debate said nothing about Congress's authority under the Necessary and Proper Clause to reserve for itself limited power to remove an official who performed some executive functions."); Peter L. Strauss, On the Difficulties of Generalization - PCAOB in the Footsteps of Myers, Humphrey's Executor, Morrison, and Freytag, 32 CARdozo L. REV. 2255, 2259 (201 I) ("[T]he decision of I789, as such, was not to state explicitly [the President's] authority to remove, but rather to reject proposals that would have provided for senatorial participation in removal.").

301 See, e.g., I CORWIN ON THE CONSTITUTION 332 (Richard Loss ed., I98I) (discussing the variation of opinion among House members who voted in favor of the Decision of I 789); DAVID P. Currie, The Constitution in Congress: The Federalist Period i789-i80i, at 4I (I997). 
as the Postmaster General and the Attorney General, would hold office until one month after the term of the President who appointed them, "subject to removal by and with the advice and consent of the Senate." 302 President Andrew Johnson initially vetoed the Act on constitutional grounds, ${ }^{303}$ but Congress overrode the veto. ${ }^{304}$ Despite the Act, Johnson attempted to remove his Secretary of War unilaterally. That attempt became the legal basis for his impeachment by the House, after which he came within a single vote in the Senate of being removed from office. ${ }^{305}$ Later administrations continued to object to the Tenure of Office Act, and Congress ultimately repealed it in I 887. ${ }^{306}$ In the meantime, Congress in I 876 passed separate legislation requiring senatorial advice and consent before the President could remove certain postmasters. ${ }^{307}$

The postmaster legislation was at issue in the Supreme Court's I 926 decision in Myers v. United States. ${ }^{308}$ There, the Court upheld the President's power to remove a postmaster without Senate approval and declared the statutory requirement of Senate approval unconstitutional. ${ }^{309}$ In doing so, it invoked historical practice in two ways. First, it relied on early practice from shortly after the constitutional Founding, in particular a broad reading of the Decision of I789. Rather than merely confirming the existence of a presidential removal authority not constitutionally subject to senatorial advice and consent, Myers took the Decision of I 789 to mean that Congress may not by legislation insert itself (or either of its chambers) into the removal decision. ${ }^{310}$ This mode of argument is distinct from the concept of the accumulation of a historical gloss over time and relies instead on the idea

302 Tenure of Office Act of I867, ch. I54, § I, I4 Stat. 430, 430 (repealed I887).

303 See Andrew Johnson, Veto Message to the Senate (Mar. 2, I867), reprinted in 8 A COMPILation of the Messages And PAPERs of the PResidents 3690 (James D. Richardson ed., I 9I 7) [hereinafter MESSAGES AND PAPERS].

304 See 8 id. at 3502 .

305 See i TRial of Andrew Johnson, President of the United States, Before THE SEnATE of THE United StATES, ON IMPEACHMENT BY THE House OF REPRESENTATIVES FOR HIGH CRIMES AND MisdemeANORS 6-IO (I868) (reciting articles of impeachment); 2 id. at 486-87, 496-98 (describing Senate vote).

306 See Grover Cleveland, Message to the Senate (Mar. I, I886), reprinted in I I MESSAGES AND PAPERS, supra note 303, at 4960; see also Louis Fisher, Grover Cleveland Against the Senate, 7 Cong. STUd. I I (I979); Jerry L. Mashaw, Federal Administration and Administrative Law in the Gilded Age, I I 9 YALE L.J. I362, I383-84, I462-63 (2010).

307 Act of July I2, I876, ch. I 79, § 6, I9 Stat. 78, 80-8I.

308272 U.S. 52 (I926).

309 Id. at I6 I (concluding that for Congress "to draw to itself, or to either branch of it, the power to remove or the right to participate in the exercise of that power ... would be ... to infringe the constitutional principle of the separation of governmental powers").

310 See id. at II ("[A]s [the President's] selection of administrative officers is essential to the execution of the laws by him, so must be his power of removing those for whom he can not continue to be responsible."). 
that some aspects of the Constitution could be "liquidated" or "fixed" by early decisions and actions. ${ }^{311}$ The Court's second use of historical practice, however, is more in the nature of historical gloss. It pointed to post-Founding practice that it deemed consistent with the purported early liquidation: "[F]rom I 789 until I863, a period of 74 years, there was no act of Congress, no executive act, and no decision of this court at variance with the declaration of the First Congress ...."312 The Court took that history to reflect an "acquiescence by all branches of the government in the legislative decision of I $789 . " 313$

At the same time, the Court in Myers declined to credit Congress's efforts to insert itself into removal decisions starting in I863. In so doing, the Court emphasized that the executive branch had consistently resisted those incursions. ${ }^{314}$ As the Court put it, ever since the Decision of $\mathrm{I} 789$, " $[\mathrm{w}] \mathrm{h}$ enever there has been a real issue in respect of the question of Presidential removals, the attitude of the Executive ... has been clear and positive against the validity of such legislation." 315 True, starting in 1863 , Presidents had signed into law some restrictions on the removal power, including the 1876 legislation at issue in Myers itself. But the Court thought those instances were "all to be explained, not by acquiescence therein, but by reason of the otherwise valuable effect of the legislation approved." 316 In downplaying those expressions of executive approval while privileging various expressions of executive disapproval, the Court announced a high standard for what could count as executive acquiescence: "When instances which actually involve the question are rare, or have not in fact occurred, the weight of the mere presence of acts on the statute book for a considerable time, as showing general acquiescence in the legislative assertion of a questioned power, is minimized." ${ }^{17}$ On this view, full executive acquiescence entails not simply signing laws that impose what might otherwise appear to be unconstitutional restrictions on executive power, but also consistently acceding to those restrictions in practice.

We do not seek here to criticize or to affirm the approach to historical practice in Myers. Instead, we aim to highlight the salient aspects of the approach. Most notably, Myers is an example of the general trend noted in section I.B.3: the more an interpreter deems nonpractice

311 See id. at I 75 ("This Court has repeatedly laid down the principle that a contemporaneous legislative exposition of the Constitution when the founders of our Government and framers of our Constitution were actively participating in public affairs, acquiesced in for a long term of years, fixes the construction to be given its provisions."); see also supra note 47 .

312 Myers, 272 U.S. at I63.

313 Id.

314 See id. at I66-70 (describing this resistance).

315 Id. at $\mathrm{I} 72$.

$316 I d$. at $\mathrm{I} 7 \mathrm{O}$

317 Id. at $\mathrm{I} 7 \mathrm{I}$. 
materials to provide a clear constitutional answer to the question at hand, the less inclined the interpreter will be to allow historical practice to change the Constitution's meaning. In Myers, precisely because the Court took the Decision of I 789 to point clearly against the legislative restriction at issue, it set a very strict standard for the kind of historical practice that might potentially change the outcome - a standard that, not surprisingly, the Court determined had not been met.

When the interpreter views the nonpractice materials as less clear, however, the standard for historical gloss appears to be less stringent. For example, although the Court has long treated it as settled that "Congress cannot reserve for itself the power of removal of an officer charged with the execution of the laws except by impeachment,"318 it has also long been accepted that Congress can abolish federal offices it had previously created by statute, with the effect of removing the incumbent. ${ }^{319}$ Today, many agree that there must be limitations on this power when applied to executive offices, lest it be used to circumvent entirely the President's control over removal. President Nixon, for example, vetoed a bill that would have removed the Director and Deputy Director of the Office of Management and Budget by abolishing and then recreating their offices in vacant form, stating in his veto message that this amounted to "a back-door method of circumventing the President's power to remove." ${ }^{20}$ But the lack of a specific textual reference to this limitation in the Constitution makes its precise scope unclear, providing more room for historical practice to be dispositive. Adhering to the line drawn by President Nixon, the executive branch has successfully resisted the simultaneous termination and recreation of an office. ${ }^{321}$ It seems reasonable to say that such legislation is "offlimits today."322 Beyond that, however, the answers are less apparent.

318 Bowsher v. Synar, 478 U.S. 7I4, 726 (I986).

319 See The Constitutional Separation of Powers Between the President \& Cong., 20 Op. O.L.C. I 24, I70 (I996) ("Congress has the general authority to legislate in ways that in fact terminate an executive branch officer's or employee's tenure by defunding a position ...."); FISHER, supra note 86 , at 80 ("Congress may remove an individual by abolishing the office."). An early example (though outside the Article II context) is the Repeal Act of 1802 , which terminated a number of federal judgeships previously created by the Judiciary Act of $180 \mathrm{I}$ and in so doing removed the incumbents. See Repeal Act, ch. 8, 2 Stat. I32 (I802) (eliminating judgeships created by the Judiciary Act of I80I, ch. 4, § 2 I, 2 Stat. 89, 96).

320 Veto of a Bill Requiring Senate Confirmation of the Director and Deputy Director of the Office of Management and Budget, I973 PUB. PAPERS 539 (May I8, I973). Congress failed to override the veto. See i i9 CONG. REC. I6,773 (1973).

321 See Status of the Dir. of Cent. Intelligence Under the Nat'l Sec. Intelligence Reform Act of 2004, 29 Op. O.L.C., 2005 WL 3733197, at*6 (Jan. I2, 2005) ("Congress may not accomplish a removal through 'ripper' legislation, whereby Congress ostensibly abolishes an office while simultaneously recreating it and requiring a new appointment."); Constitutional Separation of Powers, 20 Op. O.L.C. at I 7 I (same).

322 Fisher, supra note 86 , at 83 . 
Although the executive branch might be inclined to react similarly to a two-step legislative move separated by a week or a month, thus far the question appears not to have arisen and thus there is no practice upon which to rely.

Historical practice can also play a more robust role than suggested in Myers by creating facts on the ground that the courts may be reluctant to challenge. This helps explain the Court's approach, after Myers, to congressional restrictions on presidential removal powers. Although Myers involved a statute requiring direct congressional participation in removal decisions, the reasoning in the decision potentially implicated a much broader set of legislative restrictions. These included provisions permitting the President to remove officers only for certain reasons, such as "inefficiency, neglect of duty, or malfeasance in office." 323 At the time Myers was decided, such "for-cause" removal restrictions were present in the legislation creating the Interstate Commerce Commission and the Federal Trade Commission, among others. In I935, the Court in Humphrey's Executor v. United States upheld the restrictions in the Federal Trade Commission Act. ${ }^{324}$ In so doing, it acknowledged that language in Myers tended to support an illimitable presidential removal authority, but it downplayed those passages as dicta. ${ }^{325}$ Yet instead of overruling Myers, the Court focused on "the character of the office" in question, ${ }^{326}$ distinguishing between purely executive offices on the one hand and "quasi-legislative" or "quasi-judicial" offices on the other. ${ }^{327}$ Under Myers, the President has an illimitable removal authority with respect to the former; under Humphrey's Executor, Congress may impose for-cause removal restrictions with respect to the latter. ${ }^{328}$

Myers and Humphrey's Executor arguably embrace very different positions on fundamental questions of presidential power and congressional-executive relations. That is not our concern for present purposes, however. Instead, Humphrey's Executor is useful here for its evident unwillingness to undercut the emerging administrative state for its willingness, in other words, to privilege an emerging historical practice. Fifty years later, the Court in Morrison v. Olson signaled an

\footnotetext{
323 See, e.g., I5 U.S.C. § 4I (2006) (permitting the President to remove members of the Federal Trade Commission "for inefficiency, neglect of duty, or malfeasance in office").

324295 U.S. 602, 632 (I 935 ).

325 See id. at 626.

326 Id. at 63 I.

327 See id. at $627-28$.

328 See id. at $63 \mathrm{I}-32$. Even with respect to purely executive officials, Congress retains "a wide assortment of tools to force federal workers out of office, even at the top policymaking level." FISHER, supra note 86 , at 80 . These tools include the power to conduct oversight investigations, which can reveal incompetence or abuse and thus effectively force removal or resignation. See id. at $8 \mathrm{I}$.
} 
even stronger inclination to accept certain then-well-developed features of the modern administrative state, including statutory limits on removal authority. ${ }^{329}$ The case involved the constitutionality of a provision of the Ethics in Government Act that prohibited the Attorney General from removing an independent counsel appointed under the Act (who the Court in Morrison held to be an inferior officer), except for good cause. ${ }^{330}$ In upholding the restriction, the Court reaffirmed the holdings of both Myers and Humphrey's Executor but shifted the analysis away from whether the officer being removed is "purely executive" as opposed to "quasi-judicial" or "quasi-legislative," and toward a more functional analysis. As the Court put it, "the real question is whether the removal restrictions are of such a nature that they impede the President's ability to perform his constitutional duty, and the functions of the officials in question must be analyzed in that light." 331 The Court found no such impediments in the restrictions on the removal of the independent counsel. ${ }^{332}$

For our purposes, Morrison's significance lies less in its holding on the independent counsel statute and more in its implications for the administrative state generally. To be sure, the Court retained the core idea of Myers that there are certain presidentially appointed officials whom the President must be able to remove at will. Thus, in the wake of Morrison, OLC opined that a statute limiting the President's power to remove the Secretary of Defense "would be plainly unconstitutional," and it predicted the courts would agree. ${ }^{333}$ That seems right. But by moving away from the "purely executive" versus "quasijudicial" or "quasi-legislative" framework, the Court in Morrison also made it easier to uphold the typical legislative structure of an independent agency, without having to pretend that such agencies exercise no executive power. This was a judicial bow to custom insofar as, by the late I980s, independent agencies with for-cause removal restrictions had become a central feature of the modern administrative

329487 U.S. 654, 696-97 (I988).

330 See 28 U.S.C. \$ 596(a)(I) (2006). The Act provided for the appointment of an independent counsel by a special division of the U.S. Court of Appeals for the D.C. Circuit, upon application to it by the Attorney General. See id. $\$ \S 592-593$.

331 Morrison, 487 U.S. at 69i. For a defense of a functional approach similar to the one the Court would ultimately adopt in Morrison, see Peter L. Strauss, The Place of Agencies in Government: Separation of Powers and the Fourth Branch, 84 COLUM. L. REV. 573, 622-25 (I984).

332 Morrison, 487 U.S. at 69I-92 (finding "no real dispute that the functions performed by the independent counsel are 'executive' in the sense that they are law enforcement functions that typically have been undertaken by officials within the Executive Branch," but stating "we simply do not see how the President's need to control the exercise of that discretion is so central to the functioning of the Executive Branch as to require as a matter of constitutional law that the counsel be terminable at will by the President").

333 The Constitutional Separation of Powers Between the President \& Cong., 20 Op. O.L.C. I24, I69 (I996). 
state. ${ }^{334}$ By refraining from calling those provisions into question, the Court may well have acted on a sense of its own limited judicial capacity to overturn well-established features of modern government.

The Court's recent decision in Free Enterprise Fund v. Public Company Accounting Oversight Board (PCAOB) is consistent with this pattern. ${ }^{335}$ There, the Court accepted as controlling the parties' agreement that members of the Securities and Exchange Commission (SEC) "cannot... be removed by the President except under the Humphrey's Executor standard of 'inefficiency, neglect of duty, or malfeasance in office," ${ }^{336}$ even though the statute creating the SEC contained no such express limitation. ${ }^{337}$ Proceeding on that understanding, the Court held that the "dual for-cause limitations" on removal of Public Company Accounting Oversight Board members - pursuant to which they could be removed by the SEC only for cause, and the SEC members were removable by the President only for cause - contravened the separation of powers. ${ }^{338}$ The removal scheme was unconstitutional, in other words, because of a feature that was nowhere explicitly stated in the scheme itself. The Court's acceptance of an extratextual for-cause limitation reveals the depth of the modern understanding that independent agencies are designed to be shielded from at-will removal. Indeed, $P C A O B$ might well be understood to grant "the independence of independent agencies... a quasiconstitutional status." ${ }^{39}$ Whatever the current Court might think about independent agencies in theory, in practice they are now such an ingrained feature of modern government that the Court appears deeply reluctant to challenge their core characteristics, including for-cause removal protections. That reluctance is consistent, moreover, with the Court's emphasis in $P C A O B$ that the dual for-cause limitations directly at issue in the case were highly unusual, and thus that its decision

334 It is noteworthy that although the Solicitor General as amicus curiae in Morrison argued against the constitutionality of the removal restrictions in the independent counsel statute, his brief "emphasize[d] that the removability of members of 'independent agencies' presents a quite different question" and identified numerous grounds upon which the Court might be able to distinguish the independent counsel from independent agencies. Brief for the United States as Amicus Curiae Supporting Appellees at 32-33, Morrison, 487 U.S. 654 (No. 87-I279), I988 WL I03 I 600 , at $* 32-33$.

335 I30 S. Ct. 3 I 38 (2010).

336 Id. at 3 I 48.

337 See id. at 3148-49.

338 Id. at 3 I 5 I.

339 Jack M. Beerman, An Inductive Understanding of Separation of Powers, 63 ADMIN. L. REV. 467, 49I (201 I); see also Strauss, supra note 300, at 2274 (arguing that PCAOB confirms that "[i]n at least some settings, Congress can create elements of the executive branch whose heads are removable only 'for cause'”). 
striking down that arrangement had few or no implications for the rest of the administrative state. ${ }^{340}$

These case studies underscore a point made in Part I - that practice-based argumentation arises in a variety of constitutional debates relating to the separation of powers. They also highlight some of the factors that commonly shape this mode of argumentation. For example, the extent to which an interpreter credits historical practice will depend in part on the intepreter's constitutional methodology and the degree to which other materials - such as constitutional text appear to offer clear guidance. Moreover, as with any precedent- or custom-oriented approach, there can be uncertainties about whether current controversies are sufficiently analogous to past practice. Functional and other normative considerations are likely to play at least some role in resolving such questions of fit.

The case studies especially highlight the difficulties associated with grounding a practice-based argument in a claim that the affected institution has acquiesced. It is often unclear what should count as acquiescence, and treating apparent institutional silence as acquiescence might overlook certain expressions of institutional nonacquiescence. That risk is especially acute with Congress, and the case studies confirm the importance of looking to various forms of soft law when assessing congressional responses to executive action. Greater attention to the more informal, nonbinding ways members of Congress articulate their views will likely narrow the range of executive actions to which Congress can be said to have acquiesced. In contrast, differences in institutional structure and capacity suggest that inaction or apparent concessions by the Executive should more readily be treated as acquiescence, especially if repeated across multiple presidential administrations.

Finally, the case studies stand as reminders of some of the limitations on judicial review in this area. On many but not all separation of powers issues, judicial involvement is relatively limited. That is certainly true in the war powers and congressional-executive agreement areas. The courts' reluctance to play a more central role in such matters might be based in part on a perception that they lack suffi-

340 See $P C A O B$, I30 S. Ct. at 3159-6r. Even if it is true that "[t]he Court's logic [in PCAOB] can lead to the conclusion that even one layer of for-cause removal protection is unconstitutional," Neomi Rao, A Modest Proposal: Abolishing Agency Independence in Free Enterprise Fund v. PCAOB, 79 FORDHAM L. REV. 254I, 2544 (20II), historical gloss is potentially significant precisely because it can alter what otherwise might seem to follow logically from conceptual constitutional reasoning. 
cient information and expertise to make major interventions, and in part on a concern that dismantling longstanding institutional practices could jeopardize their own legitimacy. Still, if courts have abstained because of a belief in Madisonian checks and balances, this Article provides an argument for reconsidering that abstention.

\section{CONCLUSION}

In this Article, we have attempted to unpack the role of historical institutional practice in interpreting the Constitution's distribution of authority within the federal government. Our aim has been to specify what is entailed in historical practice-based arguments about executive and legislative power, and to identify the factors that are critical for evaluating such arguments. Most accounts of the role of historical practice in the separation of powers context assume a Madisonian model, pursuant to which Congress and the President each have the tools and the motivation to resist encroachments on their authority. That assumption has been substantially undercut by modern political science scholarship, especially with respect to Congress. Ultimately, the problems with the Madisonian model are not fatal to crediting historical practice in interpreting the separation of powers, but they do require more attention to the reasons why such practice is invoked, the extent to which those reasons demand institutional acquiescence, and the precise method by which such acquiescence is identified. 